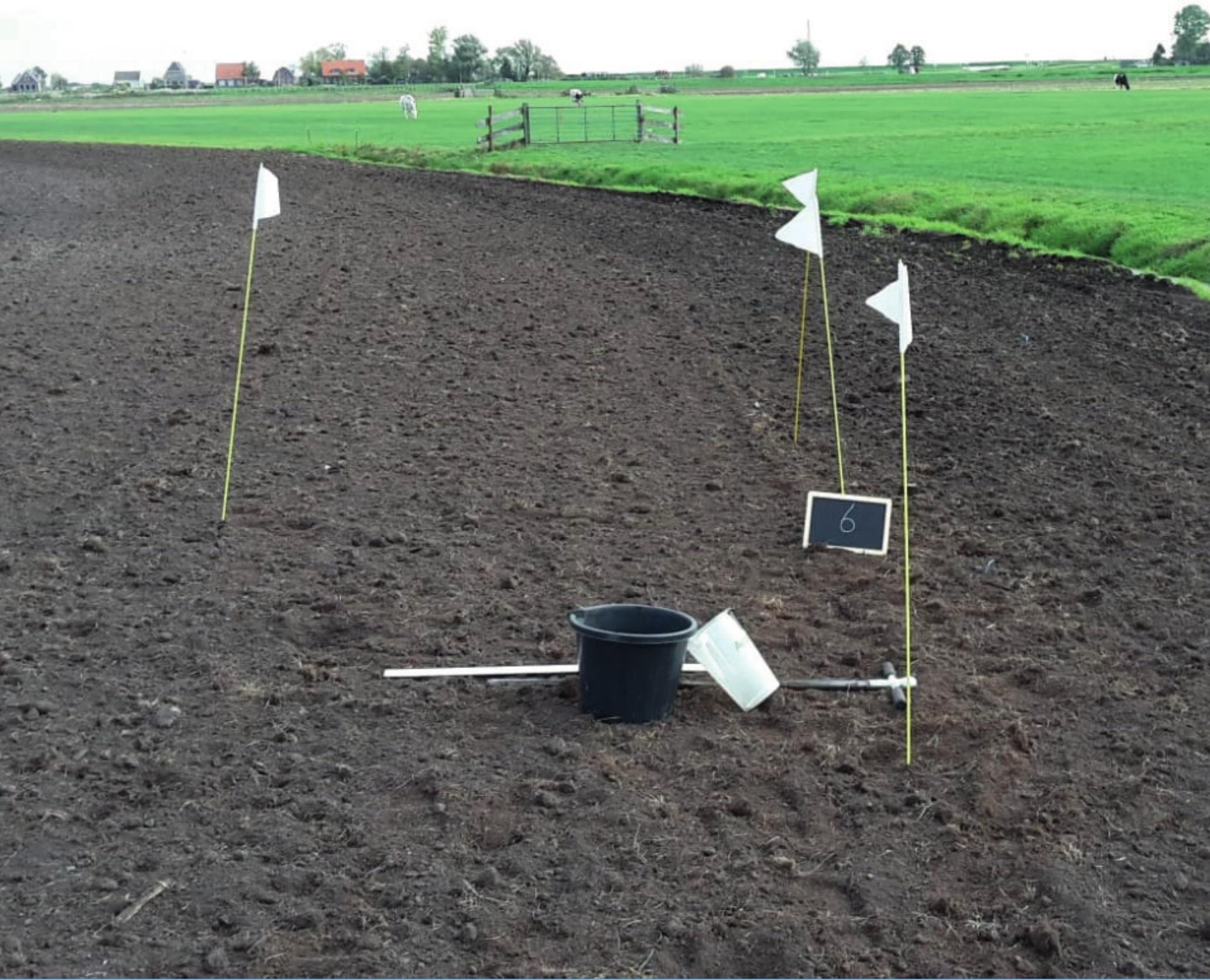

\title{
Koolstofvoorraad in de bodem van Nederland (1998-2018)
}

CC-NL

Dorothée van Tol-Leenders, Martin Knotters, Willy de Groot, Paul Gerritsen, Arjan Reijneveld,

Fenny van Egmond, Henk Wösten, Peter Kuikman 



\section{Koolstofvoorraad in de bodem van Nederland (1998-2018)}

CC-NL

Dorothée van Tol-Leenders ${ }^{1}$, Martin Knotters ${ }^{1}$, Willy de Groot ${ }^{1}$, Paul Gerritsen ${ }^{1}$, Arjan Reijneveld ${ }^{2}$, Fenny van Egmond ${ }^{1}$, Henk Wösten ${ }^{1}$, Peter Kuikman ${ }^{1}$

1 Wageningen Environmental Research

2 Eurofins

Dit onderzoek is uitgevoerd door Wageningen Environmental Research in opdracht van en gefinancierd door het ministerie van Landbouw, Natuur en Voedselkwaliteit, in het kader van het Beleidsondersteunend onderzoekthema 'Klimaat Slim landgebruik' (projectnummer BO-53-002-001).

Wageningen Environmental Research

Wageningen, december 2019

Gereviewd door:

Jan Peter Lesschen, team Duurzaam Bodemgebruik

Akkoord voor publicatie:

Mirjam Hack, teamleider van team Bodem, Water en Landgebruik

Rapport 2974

ISSN 1566-7197 
Tol-Leenders, D. van, M. Knotters, W. de Groot, P. Gerritsen, A. Reijneveld, F. van Egmond, H. Wösten, P. Kuikman, 2019. Koolstofvoorraad in de bodem van Nederland (1998-2018); CC-NL. Wageningen, Wageningen Environmental Research, Rapport 2974. 84 blz.; 54 fig.; 18 tab.; 11 ref.

De 1392 locaties van de Landelijke Steekproef Kaarteenheden werden na circa 20 jaar opnieuw bezocht om onder meer het gehalte aan organische stof en de dichtheid te bepalen. Het gehalte aan organische stof in de laag van 0 tot $30 \mathrm{~cm}$ blijkt tussen circa 1998 en 2018 significant te zijn afgenomen: van 6,85 naar $6,43 \%$. In de laag van 30 tot $100 \mathrm{~cm}$ werd een significante afname gevonden van 7,82 naar 5,11\%. Ook de koolstofvoorraden in de Nederlandse bodem bleken in de periode tussen circa 1998 en 2018 significant te zijn afgenomen. Binnen 24 deelgebieden naar bodem en landgebruik kon in bijna alle gevallen geen significante verandering worden aangetoond. Voor het deel van Nederland dat op de bodemkaart als minerale grond is gekarteerd, kon ook geen significante verandering in het gehalte aan organische stof worden aangetoond. De resultaten geven aan dat een verklaring voor afname van het landelijk gemiddelde gehalte aan organische stof ligt in oxidatie van veen en moerig materiaal. Met de ervaringen van de meetcampagne in 2018 kan de toekomstige monitoring voor post-2020 LULUCF-rapportages ter hand worden genomen, waarbij aandacht nodig is voor de effecten van veranderend landgebruik, de effecten van diepe grondbewerking, veranderingen in bodemdichtheid en de hoogte van de koolstofratio (verhouding koolstof-organische stof). Bovendien geven de resultaten aan in welke gebieden een extra meetinspanning nodig is om nauwkeurige schattingen van koolstofvoorraden en veranderingen daarin te verkrijgen.

Trefwoorden: organische stof, bodem- en landgebruik, klimaatrapportage

Dit rapport is gratis te downloaden van https://doi.org/10.18174/509781 of op www.wur.nl/environmental-research (ga naar 'Wageningen Environmental Research' in de grijze balk onderaan). Wageningen Environmental Research verstrekt geen gedrukte exemplaren van rapporten.

\section{CC license CC-BY 4.0}

2019 Wageningen Environmental Research (instituut binnen de rechtspersoon Stichting Wageningen Research), Postbus 47, 6700 AA Wageningen, T 03174807 00, www.wur.nl/environmental-research. Wageningen Environmental Research is onderdeel van Wageningen University \& Research.

- Overname, verveelvoudiging of openbaarmaking van deze uitgave is toegestaan mits met duidelijke bronvermelding.

- Overname, verveelvoudiging of openbaarmaking is niet toegestaan voor commerciële doeleinden en/of geldelijk gewin.

- Overname, verveelvoudiging of openbaarmaking is niet toegestaan voor die gedeelten van deze uitgave waarvan duidelijk is dat de auteursrechten liggen bij derden en/of zijn voorbehouden.

Wageningen Environmental Research aanvaardt geen aansprakelijkheid voor eventuele schade voortvloeiend uit het gebruik van de resultaten van dit onderzoek of de toepassing van de adviezen.

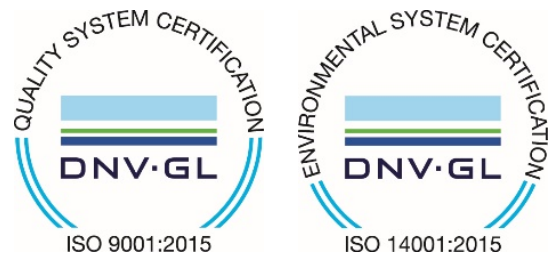

Wageningen Environmental Research werkt sinds 2003 met een ISO 9001 gecertificeerd kwaliteitsmanagementsysteem. In 2006 heeft Wageningen Environmental Research een milieuzorgsysteem geïmplementeerd, gecertificeerd volgens de norm ISO 14001.

Wageningen Environmental Research geeft via ISO 26000 invulling aan haar maatschappelijke verantwoordelijkheid.

Wageningen Environmental Research Rapport 2974 | ISSN 1566-7197 


\section{Inhoud}

$\begin{array}{ll}\text { Verantwoording } & 5\end{array}$

$\begin{array}{ll}\text { Woord vooraf } & 7\end{array}$

$\begin{array}{ll}\text { Beleidssamenvatting } & 9\end{array}$

$\begin{array}{lr}1 & \mathbf{2 1}\end{array}$

1.1 Achtergrond $\quad 21$

1.2 Doel $\quad 21$

$\begin{array}{lll}1.3 & \text { Opzet rapport } & 21\end{array}$

2

$\begin{array}{ll}\text { Aanpak } & \mathbf{2 2}\end{array}$

$\begin{array}{lll}2.1 & \text { Bemonstering, laboratoriumanalyses } & 22\end{array}$

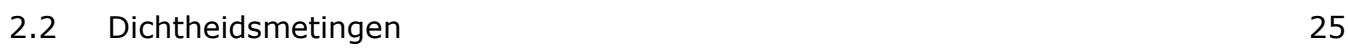

$\begin{array}{lll}2.3 & \text { Dataverwerking } & 25\end{array}$

2.3.1 Analyse op landelijk niveau $\quad 25$

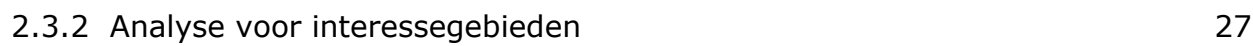

2.3.3 Indeling in interessegebieden volgens stratificatie van de LSK 27

2.3.4 Indeling in interessegebieden volgens waarnemingen op LSK-locaties 27

$3 \quad$ Resultaten $\quad 30$

$\begin{array}{lll}3.1 & \text { Eerste analyse van de metingen } & 30\end{array}$

$\begin{array}{lll}3.2 & \text { Actuele koolstofvoorraad } & 31\end{array}$

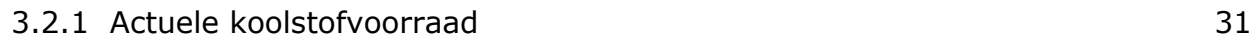

$\begin{array}{lll}3.3 & \text { Veranderingen in de koolstofvoorraad } & 32\end{array}$

3.3.1 Alle gronden in Nederland $\quad 32$

3.3.2 Minerale gronden $\quad 33$

3.3.3 Veen- en moerige gronden $\quad 35$

3.4 Domeinschattingen voor combinaties van landgebruik en bodemtype 41

3.4.1 Indeling in vier landgebruikscategorieën en zes bodemtypen 41

3.4.2 Indeling in vier landgebruikscategorieën en elf bodemtypen 43

$\begin{array}{ll}3.5 & \text { Indringingsweerstand } \\ \end{array}$

$\begin{array}{lll}4.1 & \text { Gehalte aan organische stof } & 51\end{array}$

4.2 Invloed veranderend landgebruik $\quad 53$

4.3 Bodemdichtheid en indringingsweerstanden $\quad 53$

4.4 Koolstofratio $\quad 56$

4.5 Monitoring $\quad 57$

4.6 Kennisvragen $\quad 58$

$\begin{array}{ll}\text { Literatuur } & 61\end{array}$

$\begin{array}{lll}\text { Bijlage } 1 \text { Wijze van bemonstering } & 62\end{array}$

$\begin{array}{lll}\text { Bijlage } 2 & \text { Punten per deelgebied } & 74\end{array}$

$\begin{array}{lll}\text { Bijlage } 3 & \text { Nieuwe technieken } & 76\end{array}$

$\begin{array}{lll}\text { Bijlage } 4 & \text { Analyse-methoden } & 83\end{array}$ 



\section{Verantwoording}

Rapport: 2974

Projectnummer: 5200045805

Wageningen Environmental Research (WENR) hecht grote waarde aan de kwaliteit van onze eindproducten. Een review van de rapporten op wetenschappelijke kwaliteit door een referent maakt standaard onderdeel uit van ons kwaliteitsbeleid.

Akkoord Referent die het heeft beoordeeld,

functie: $\quad$ Senior onderzoeker bodem en klimaat

naam: Jan Peter Lesschen

datum: $\quad 30-11-2019$

Akkoord teamleider voor de inhoud,

naam: Mirjam Hack

datum: $\quad 30-11-2019$ 


\section{Woord vooraf}

"Alles wordt een beetje minder

Je wil nie weten waar 't allemaal aan schort"

... zo begint een liedje van de Nijmeegse columnist, correspondent, adjunct-hoofdredacteur en liedjesschrijver Marc de Koninck (https://www.deliedjeskrant.nl/en/song.php?recordID=7). Met de voorraad aan koolstof in de Nederlandse bodem wordt het ook een beetje minder, maar wij willen wel graag weten waar het aan schort.

Gelukkig beschikken wij in Nederland over een mooie dataset, de Landelijke Steekproef Kaarteenheden, die ons in staat stelt om statistisch onderbouwde uitspraken te doen over veranderingen in gehalten aan organische stof en, daarmee samenhangend, veranderingen in de koolstofvoorraad. Dit rapport doet verslag van een veldcampagne waarbij de 1392 locaties van de Landelijke Steekproef Kaarteenheden na circa 20 jaar opnieuw werden bezocht, onder meer om opnieuw het gehalte aan organische stof te bepalen.

Het veldwerk was een logistieke operatie van formaat, waarbij wij aan iedere betrokkene dank verschuldigd zijn. In de eerste plaats gaat onze dank uit naar de eigenaren en gebruikers van de percelen waarin de locaties van de Landelijke Steekproef Kaarteenheden liggen. Zij toonden zich bereidwillig ons toegang te verlenen en wij hopen ook op hun medewerking in de toekomst. In elk geval delen wij alle uitkomsten van het onderzoek met hen. Ook gaat onze dank uit naar de medewerkers van Eurofins, die deze veldcampagne en het laboratoriumwerk met niet aflatende inzet en nauwgezetheid hebben uitgevoerd. Voorts bedanken wij Leo Oprel, Gerrie Haenen, Eke Buis en Inge Lardinois, allen medewerkers van het ministerie van Landbouw, Natuur en Voedselkwaliteit, en onze collega's Jennie van der Kolk en Jan-Peter Lesschen voor hun kritische en opbouwende commentaar gedurende dit project.

Dorothée van Tol-Leenders

Martin Knotters

Willy de Groot

Paul Gerritsen

Arjan Reijneveld

Fenny van Egmond

Henk Wösten

Peter Kuikman 


\section{Beleidssamenvatting}

\section{Aanleiding en doel}

Met het Klimaatverdrag van Parijs en het Europese klimaatbeleid om ook emissies en vastlegging van koolstof in de bodem mee te laten tellen voor de klimaatdoelstelling, is het belang van het monitoren van de hoeveelheid koolstof in de bodem toegenomen. Het kabinet wil emissies uit de bodem door landgebruik verminderen en vastlegging stimuleren. De koolstofvoorraad in de bodem van Nederland in circa 1998 is bepaald aan de hand van bemonsteringgegevens van 1392 locaties van de Landelijke Steekproef Kaarteenheden (LSK). De koolstofvoorraden die hieruit zijn bepaald voor combinaties van landgebruik en bodemtype worden gebruikt in de systematiek voor de rapportage van emissies (Emissieregistratie) en vastlegging voor de LULUCF-sector (LULUCF is een acroniem voor 'Land use, land-use change and forestry', ofwel de sectoren landgebruik en bosbouw). Deze momentopname reflecteert de koolstofvoorraad zoals deze was gedurende de opname van de LSK, van ongeveer 1994 tot 2001, dus circa 1998. In 2018 gaf het ministerie van LNV opdracht om de dataset te actualiseren met het oog op komende klimaatrapportages (2020-2030). Met dit doel is in 2018 een nieuwe meetcampagne uitgevoerd en de resultaten hiervan zijn gebruikt om de verandering in koolstofvoorraad in de bodem in Nederland te berekenen over de periode 1998-2018. Voor de meetcampagne is een zorgvuldig bemonsteringsplan opgesteld, zijn de bemonsteraars getraind en is een herhaling uitgevoerd van de meting van gehalten aan organische stof in de Nederlandse bodems zoals die plaatsvond in 1998. In de 2018-meetcampagne is $15 \%$ van de in 1998 bemonsterde punten afgevallen vanwege verharding, geen toegang, sterk afwijkende waarden etc.

\section{Resultaten}

De belangrijkste resultaten staan hieronder samengevat en een uitgebreide rapportage geeft de verdere detaillering. De resultaten worden gepresenteerd op drie verschillende niveaus van aggregatie: 1) alle bodems samen, 2) minerale bodems, 3) combinatie van zes bodemtypen met vier landgebruiksklassen en tot slot kaartjes van de koolstofvoorraad in de bodem van Nederland.

Alle bodems samen

Tabel 1 Geschatte gemiddelde gehalten aan organische stof (\%) en voorraden (Mton) in de bodem van Nederland in 1998 en 2018 voor alle gronden (mineraal + organisch) die zijn bemonsterd (standaardfout tussen haakjes) met een totaaloppervlakte van 2.870 .671 ha voor de lagen $0-30 \mathrm{~cm}$ en 30-100 cm (vetgedrukte waarden zijn significant bij een significantieniveau van 0,05, tweezijdig alternatief).

\begin{tabular}{|c|c|c|c|}
\hline \multirow[t]{2}{*}{ Variabele } & \multirow[t]{2}{*}{1998} & \multirow[t]{2}{*}{2018} & Verandering \\
\hline & & & 2018-1998 \\
\hline \multicolumn{4}{|l|}{ Laag 0-30 cm } \\
\hline Voorraad org. stof (Mton) & $569,75(7,31)$ & $533,41(7,00)$ & $-36,33(7,85)$ \\
\hline \multicolumn{4}{|l|}{ Laag $30-100 \mathrm{~cm}$} \\
\hline Voorraad org. stof (Mton) & $844,49(14,46)$ & $691,66(12,62)$ & $-152,83(14,42)$ \\
\hline
\end{tabular}

Uit Tabel 1 blijkt dat in de periode 1998-2018 zowel de gehalten aan organische stof (\%) als de voorraden (Mton) voor alle gronden samen significant zijn afgenomen (bij een significantieniveau van 0.05).

Figuur 1 differentieert het landelijke beeld uit Tabel 1. De punten in de figuur tonen waar het gehalte aan organische stof is toe- of afgenomen tussen 1998 en 2018. Verdere analyse heeft laten zien dat afnames vooral in de moerige gronden plaatsvinden en niet in de minerale en veengronden. 


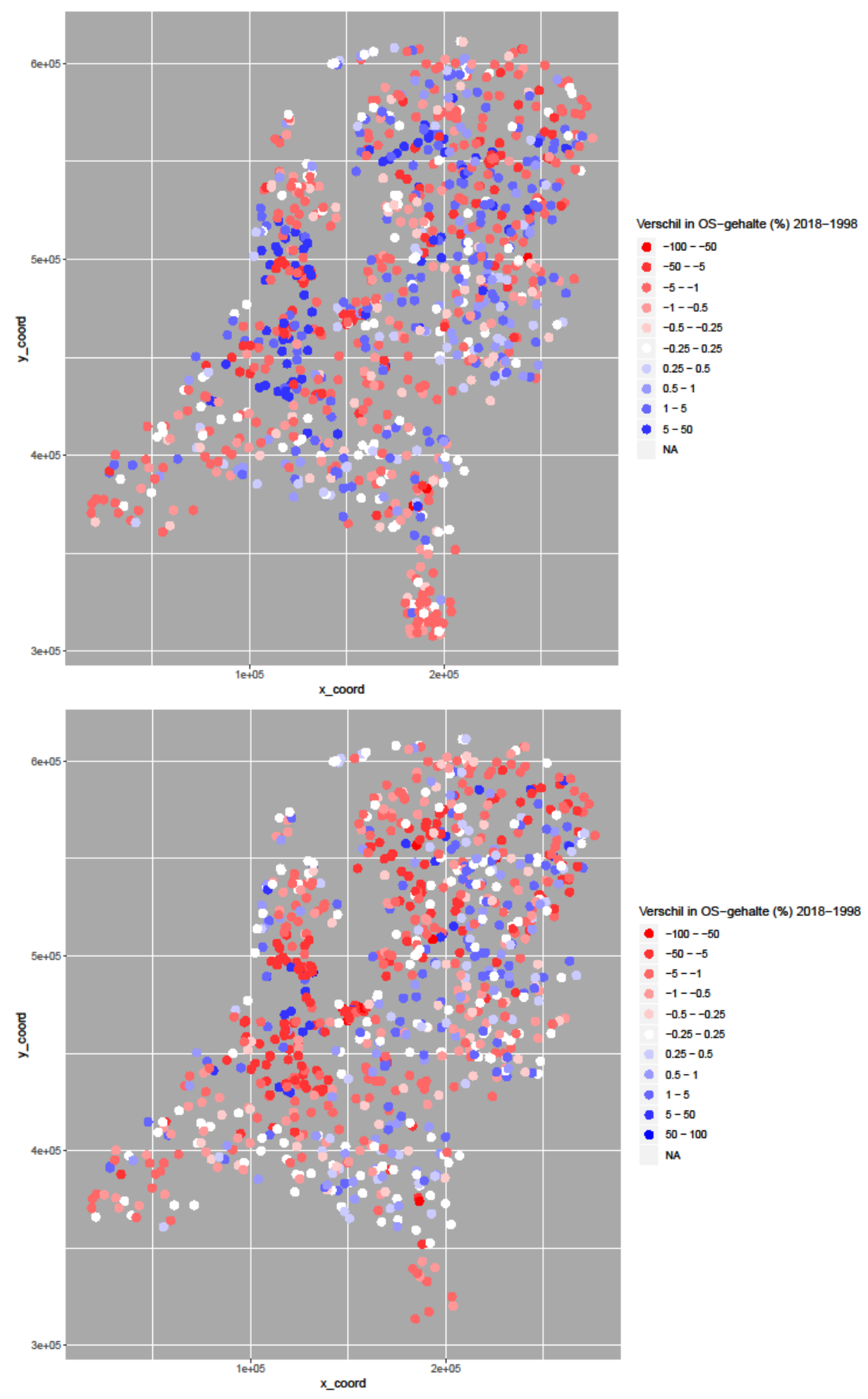

Figuur 1 Ruimtelijk beeld van de verschillen in gemeten gehalten (\%) aan organische stof voor de laag 0-30 cm (boven) en voor de laag 30-100 cm (onder) (1998-2018).

\section{Minerale bodems}

Terwijl Tabel 1 de waarden vermeldt voor alle bodems samen (mineraal + organisch) met een totaaloppervlakte van 2.870.671 ha, vermeldt Tabel 2 de waarden voor uitsluitend de minerale (zand + zavel + klei) bodems met een oppervlakte van 1.039 .521 ha (36\% van het totale areaal). 
Tabel 2 Geschatte gemiddelde gehalten organische stof (\%) en voorraden (Mton) voor minerale bodems (zand + zavel + klei volgens de bodemkaart van Nederland schaal 1:50.000) in 1998 en 2018 die zijn bemonsterd (standaardfout tussen haakjes) met een totaaloppervlakte van 1.039.521 ha (36\% van totaal areaal) voor de lagen $0-30 \mathrm{~cm}$ en $30-100 \mathrm{~cm}$ (vetgedrukte waarden zijn significant bij een significantieniveau van 0,05, tweezijdig alternatief).

\begin{tabular}{|c|c|c|c|}
\hline \multirow[t]{2}{*}{ Variabele } & \multirow[t]{2}{*}{1998} & \multirow[t]{2}{*}{2018} & Verandering \\
\hline & & & 2018-1998 \\
\hline \multicolumn{4}{|l|}{ Laag 0-30 cm } \\
\hline Gemiddeld gehalte aan org. stof (\%) & $4,01(0,11)$ & $4,11(0,13)$ & $0,10(0,13)$ \\
\hline Voorraad org. stof (Mton) & $167,46(3,97)$ & $154,44(3,67)$ & $-13,02(4,18)$ \\
\hline \multicolumn{4}{|l|}{ Laag $30-100 \mathrm{~cm}$} \\
\hline Gemiddeld gehalte aan org. stof gehalte (\%) & $1,90(0,09)$ & $1,78(0,08)$ & $-0,11(0,09)$ \\
\hline Voorraad org. stof (Mton) & $188,81(6,92)$ & $168,87(6,17)$ & $-19,95(7,34)$ \\
\hline
\end{tabular}

Uit Tabel 2 blijkt dat in de periode 1998-2018 de gehalten aan organische stof (\%) niet significant veranderen, terwijl de voorraden (Mton) wel significant zijn afgenomen voor minerale gronden (bij een significantieniveau van 0.05). Uit een nadere analyse blijkt dat dit wordt veroorzaakt doordat de dichtheden die worden gebruikt om een gehalte naar een voorraad om te rekenen, zijn afgenomen. Deze afname is mogelijkerwijs realistisch, maar kan ook worden veroorzaakt doordat in 1998 dichtheden zijn geschat met behulp van pedotransferfuncties, terwijl deze dichtheden in 2018 zijn gemeten.

Combinatie van zes bodemtypen met vier landgebruiksklassen

In samenspraak met LNV is een bodem-landgebruik-indeling gemaakt die beantwoordt aan de volgende vier criteria:

1. Duidelijk onderscheid naar grondsoort (zand, klei, leem, moerig, veen);

2. Relevant voor onderscheid naar koolstofvoorraad in de bovenste $30 \mathrm{~cm}$;

3. Reductie van het aantal bodemgroepen, resulterend in deelgebieden van voldoende omvang om de koolstofvoorraad nauwkeurig te kunnen vaststellen;

4. Onderscheiden van deelgebieden waaraan een handelingsperspectief kan worden toegekend.

Op basis van deze vier criteria is de volgende indeling in zes bodemtypen ontworpen:

1. Zandgronden met een eerdlaag, dikker dan $30 \mathrm{~cm}$;

2. Overige zandgronden;

3. Kleigronden (inclusief kleibrikgronden en oude kleigronden);

4. Leemgronden (inclusief leembrikgronden);

5. Moerige gronden (inclusief moerige podzolgronden);

6. Veengronden.

Figuur 2 toont de gehalten aan organische stof in de Nederlandse bodem in 2018 in de laag 0-30 cm en Figuur 3 de verandering in gehalten 2018 - 1998. De grootste veranderingen treden op bij moerige en veengronden, maar de veranderingen zijn meestal niet significant. Indien in Figuur 3 de error bars door de nullijn gaan dan zijn de verschillen niet significant, bij een significantieniveau van 5\%. Gaan ze niet door de nullijn, dan zijn de verschillen wel significant. Dat veranderingen niet significant (aantoonbaar) zijn, heeft te maken met een grote ruimtelijke variatie van deze veranderingen in gehalten aan organische stof enerzijds en een kleine steekproefomvang anderzijds. Zou er in werkelijkheid geen verandering zijn geweest en zou de steekproef een groot aantal keren zijn herhaald, dan zou in meer dan $5 \%$ van deze herhalingen ten onrechte worden geconcludeerd dat het gehalte aan organische stof is veranderd. Alleen bij grasland in moerige gronden is een afname van het gehalte aan organische stof aan te tonen bij een significantieniveau van $5 \%$. 


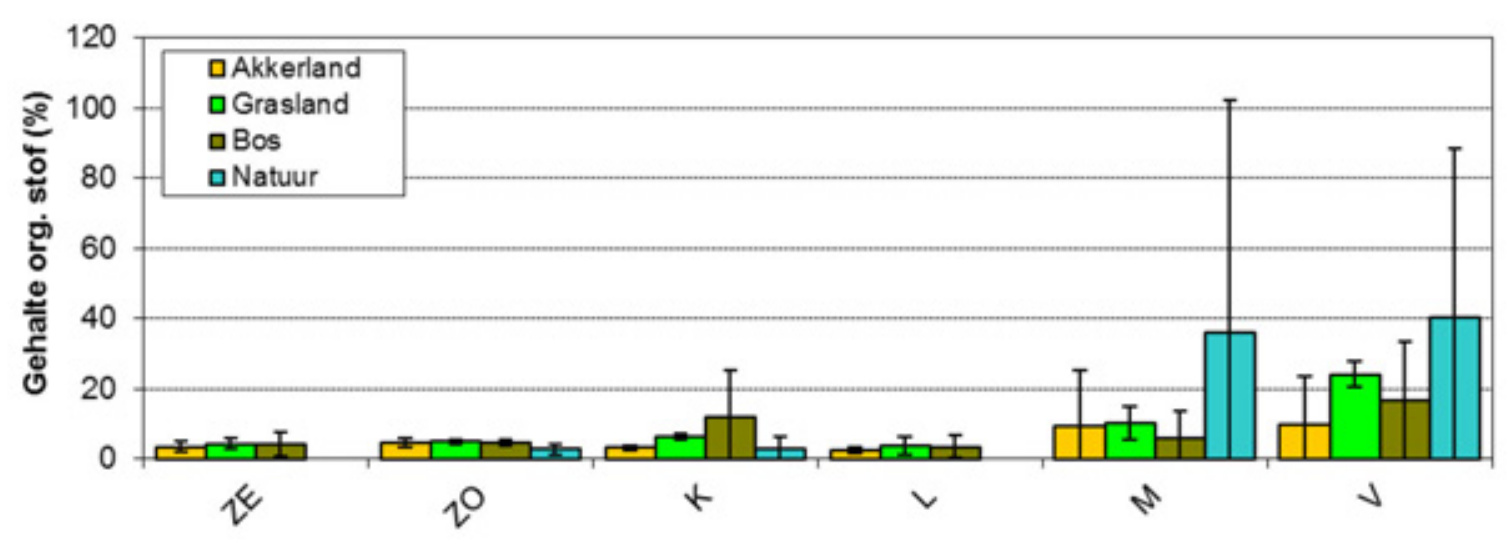

Figuur 2 Gehalten aan organische stof in de Nederlandse bodem in 2018 in de laag 0-30 cm, geschat op basis van de Landelijke Steekproef Kaarteenheden. Indeling naar landgebruik in 1998. De error bars geven 95\%-betrouwbaarheidsintervallen aan. ZE: zandgronden met een eerdlaag die dikker is dan $30 \mathrm{~cm}$; ZO: overige zandgronden; K: kleigronden; L: leemgronden; M: moerige gronden; $V$ : veengronden.

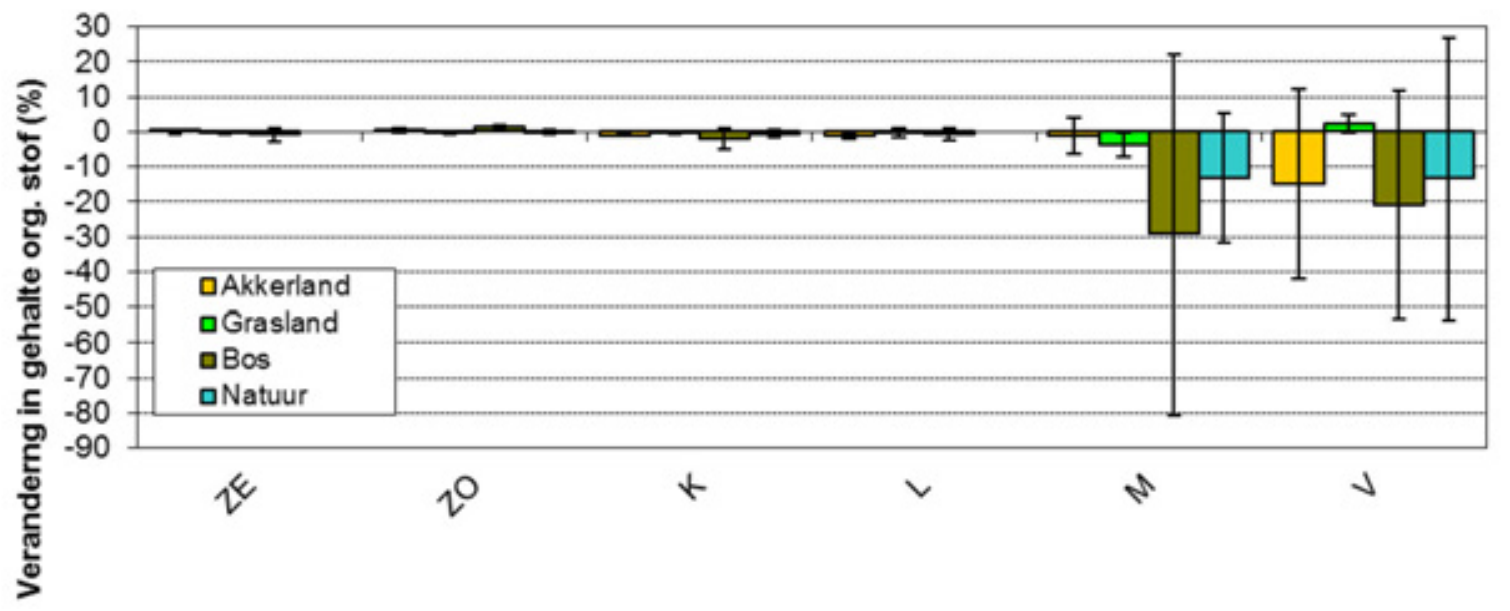

Figur 3 Verandering in gehalte aan organische stof (2018-1998) in de Nederlandse bodem in de laag 0-30 cm, op basis van de Landelijke Steekproef Kaarteenheden. Indeling naar landgebruik in 1998. De error bars geven 95\%-betrouwbaarheidsintervallen aan. ZE: zandgronden met een eerdlaag die dikker is dan $30 \mathrm{~cm}$; ZO: overige zandgronden; K: kleigronden; L: leemgronden; M: moerige gronden; $v$ : veengronden.

Figuur 4 toont de gehalten aan organische stof in de Nederlandse bodem in 2018 in de laag $30-100 \mathrm{~cm}$ en Figuur 5 de verandering in gehalten (2018-1998) in deze laag. Afnames van het gehalte aan organische stof in de laag 30-100 cm zijn aan te tonen bij akkerland, grasland en bos op klei en bij grasland op veen. 


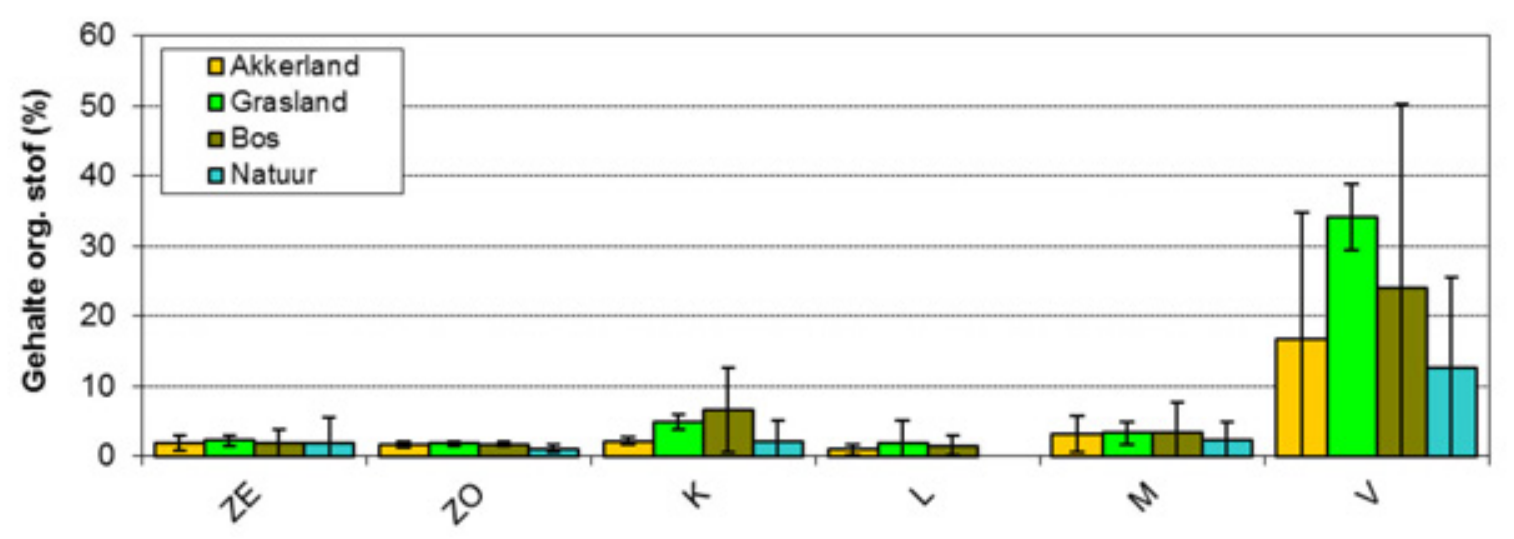

Figuur 4 Gehalten aan organische stof in de Nederlandse bodem in 2018 in de laag 30-100 cm, geschat op basis van de Landelijke Steekproef Kaarteenheden. Indeling naar landgebruik in 1998. De error bars geven 95\%-betrouwbaarheidsintervallen aan. ZE: zandgronden met een eerdlaag die dikker is dan $30 \mathrm{~cm}$; ZO: overige zandgronden; K: kleigronden; L: leemgronden; M: moerige gronden; $\checkmark$ : veengronden.

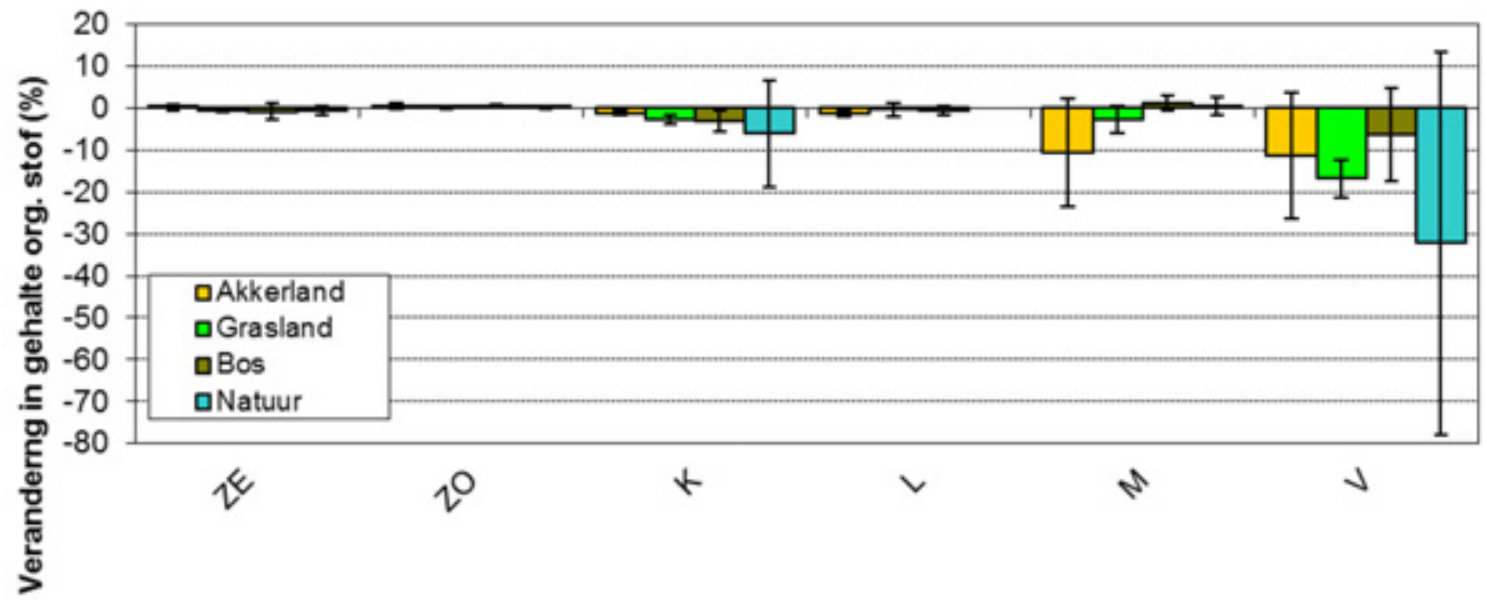

Figur $5 \quad$ Verandering in gehalte aan organische stof (2018-1998) in de Nederlandse bodem in de laag 30-100 cm, op basis van de Landelijke Steekproef Kaarteenheden. Indeling naar landgebruik in 1998. De error bars geven 95\%-betrouwbaarheidsintervallen aan. ZE: zandgronden met een eerdlaag die dikker is dan $30 \mathrm{~cm}$; ZO: overige zandgronden; K: kleigronden; L: leemgronden; M: moerige gronden; $V$ : veengronden.

Figuur 6 toont de koolstofvoorraden in de Nederlandse bodem in 2018 in de laag 0-30 cm en Figuur 7 de verandering in voorraden (2018-1998). 


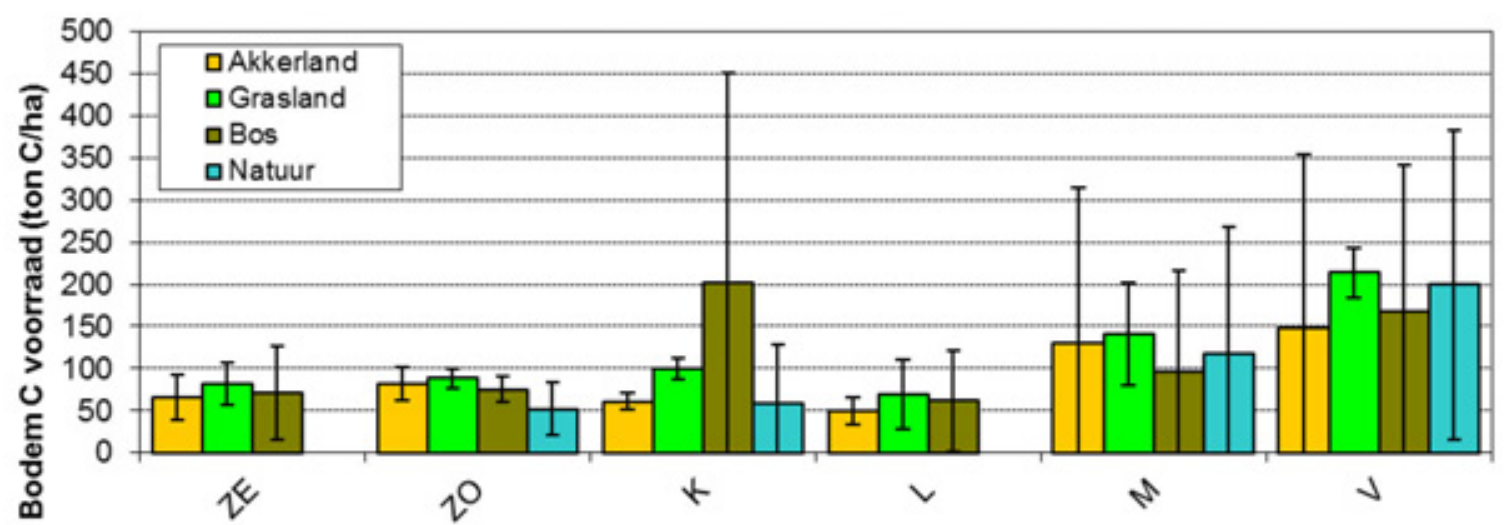

Figuur 6 Koolstofvoorraden in de Nederlandse bodem in 2018 in de laag 0-30 cm, geschat op basis van de Landelijke Steekproef Kaarteenheden. Indeling naar landgebruik in 1998. De error bars geven 95\%-betrouwbaarheidsintervallen aan. ZE: zandgronden met een eerdlaag die dikker is dan $30 \mathrm{~cm}$; ZO: overige zandgronden; K: kleigronden; L: leemgronden; M: moerige gronden; V: veengronden.

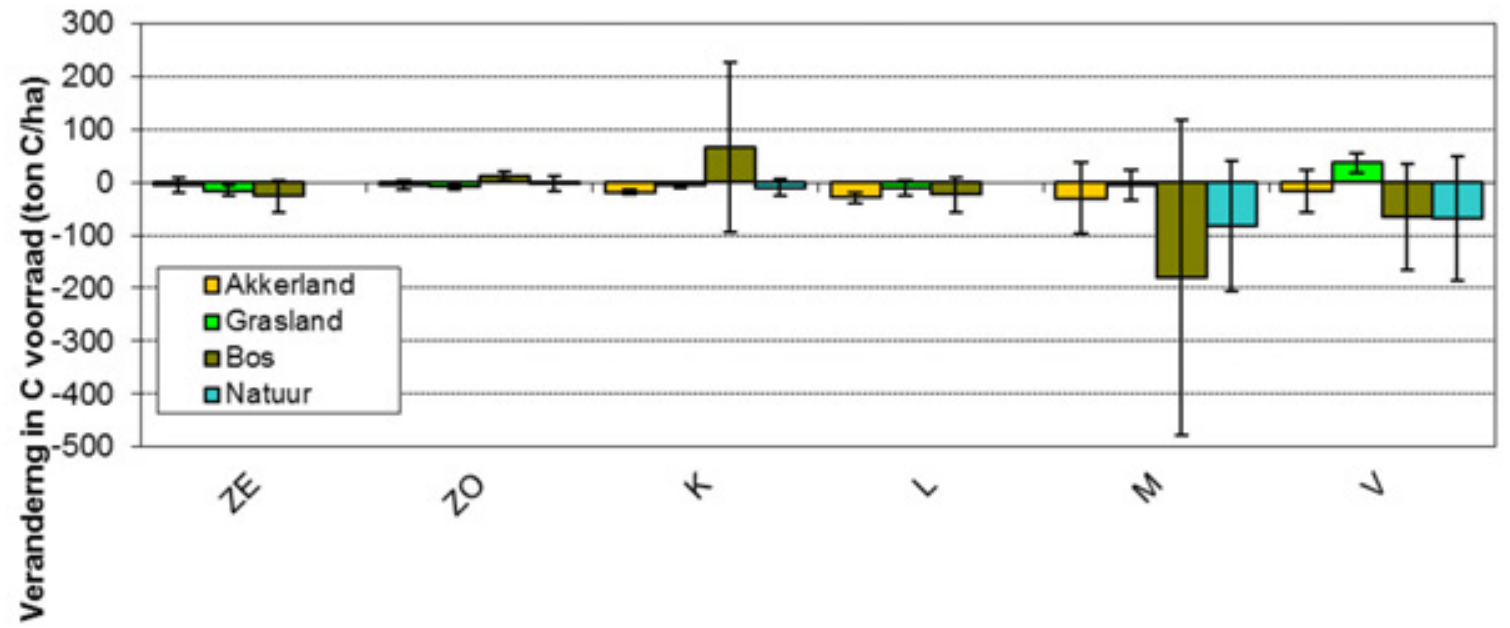

Figuur $7 \quad$ Verandering in koolstofvoorraad (2018-1998) in de Nederlandse bodem in de laag $0-30 \mathrm{~cm}$, op basis van de Landelijke Steekproef Kaarteenheden. Indeling naar landgebruik in 1998. De error bars geven 95\%-betrouwbaarheidsintervallen aan. ZE: zandgronden met een eerdlaag die dikker is dan $30 \mathrm{~cm}$; ZO: overige zandgronden; K: Kleigronden; L: leemgronden; M: moerige gronden; $\checkmark$ : veengronden.

Uit Figuur 7 komt een wisselend beeld naar voren, waarbij een afname van de koolstofvoorraad onder akkerland gedurende de laatste 20 jaar soms wel en soms niet aan te tonen is bij een significantieniveau van $5 \%$. Hetzelfde wisselende patroon doet zich voor bij graslanden, zij het bij soms andere gronden dan bij akkerland. Onder bos en overige natuur zijn de veranderingen niet aantoonbaar.

Figuur 8 toont de koolstofvoorraden in de Nederlandse bodem in 2018 in de laag $30-100 \mathrm{~cm}$ en Figuur 9 de verandering in voorraden 2018-1998. 


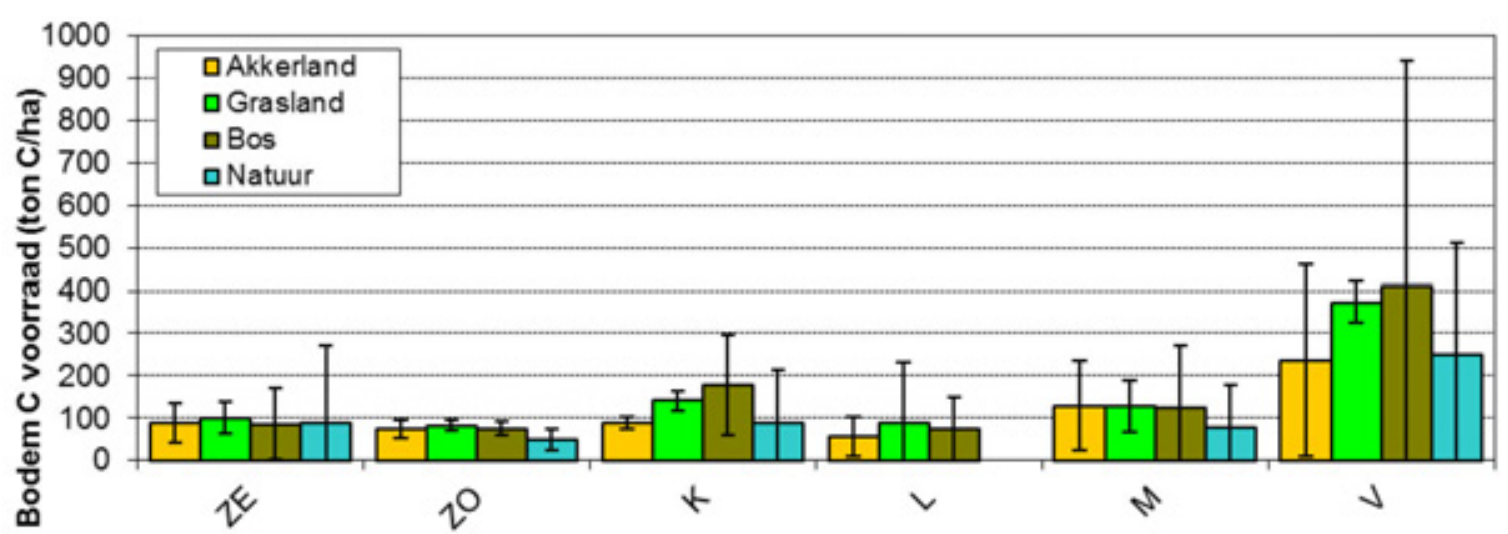

Figuur 8 Koolstofvoorraden in de Nederlandse bodem in 2018 in de laag 30-100 cm, op basis van de Landelijke Steekproef Kaarteenheden. Indeling naar landgebruik in 1998. De error bars geven 95\%betrouwbaarheidsintervallen aan. ZE: zandgronden met een eerdlaag die dikker is dan $30 \mathrm{~cm}$; ZO: overige zandgronden; K: kleigronden; L: leemgronden; M: moerige gronden; V: veengronden.

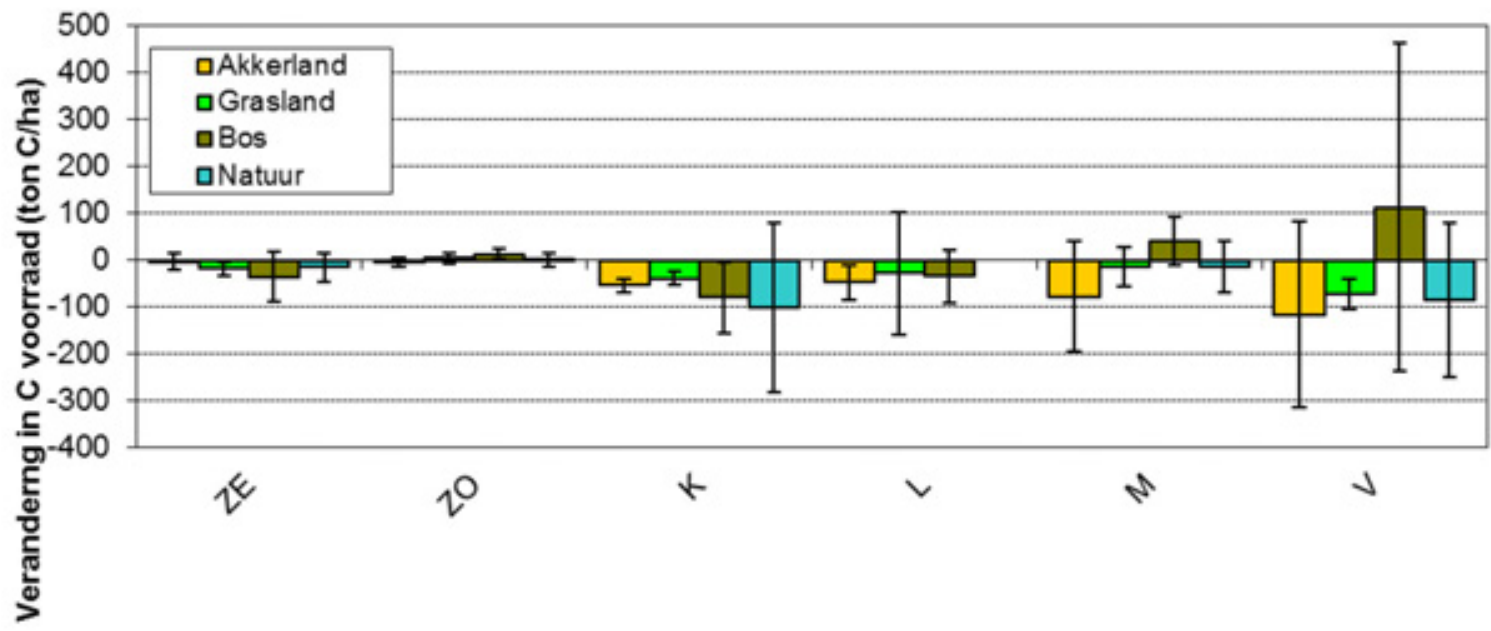

Figur 9 Verandering in koolstofvoorraad (2018-1998) in de Nederlandse bodem in de laag 30-100 cm, op basis van de Landelijke Steekproef Kaarteenheden. Indeling naar landgebruik in 1998. De error bars geven 95\%-betrouwbaarheidsintervallen aan. ZE: zandgronden met een eerdlaag die dikker is dan $30 \mathrm{~cm}$; ZO: overige zandgronden; K: kleigronden; L: leemgronden; M: moerige gronden; $V$ : veengronden.

Figuur 9 geeft een wisselend beeld, waarbij de verandering in koolstofvoorraad onder akkerland en grasland soms wel en soms niet is aangetoond bij een significantieniveau van $5 \%$. Afnames zijn aangetoond bij akkerland op klei en leem en bij grasland op klei en veen. Onder bos en overige natuur zijn overwegend geen veranderingen aan te tonen, behalve bij bos op overige zandgronden (toename) en bos op klei (afname).

Koolstofvoorraad in de bodem van Nederland

Voor alle gronden samen geeft Tabel 3 de geschatte koolstofvoorraad in de bodem van Nederland voor de laag $0-30 \mathrm{~cm}$ en $30-100 \mathrm{~cm}$ in 2018 . Figuur 10 toont de verspreiding van deze koolstofvoorraad over Nederland.

Tabel 3 Geschatte actuele koolstofvoorraad in de bodem (2.870.671 ha) van Nederland 2018 voor alle gronden die zijn bemonsterd (standaardfout tussen haakjes).

\begin{tabular}{lll} 
Variabele & Laag $0-30 \mathrm{~cm}$ & Laag $30-100 \mathrm{~cm}$ \\
Gemiddeld gehalte aan organische stof in Nederland (\%) & $6,43(0,14)$ & $5,11(0,16)$ \\
\hline Voorraad C Nederland (Mton)* & $266,71(3,50)$ & $345,83(6,31)$ \\
\hline
\end{tabular}

*Aanname $50 \%$ organische stofgehalte is koolstof en op basis van gemeten dichtheden. 


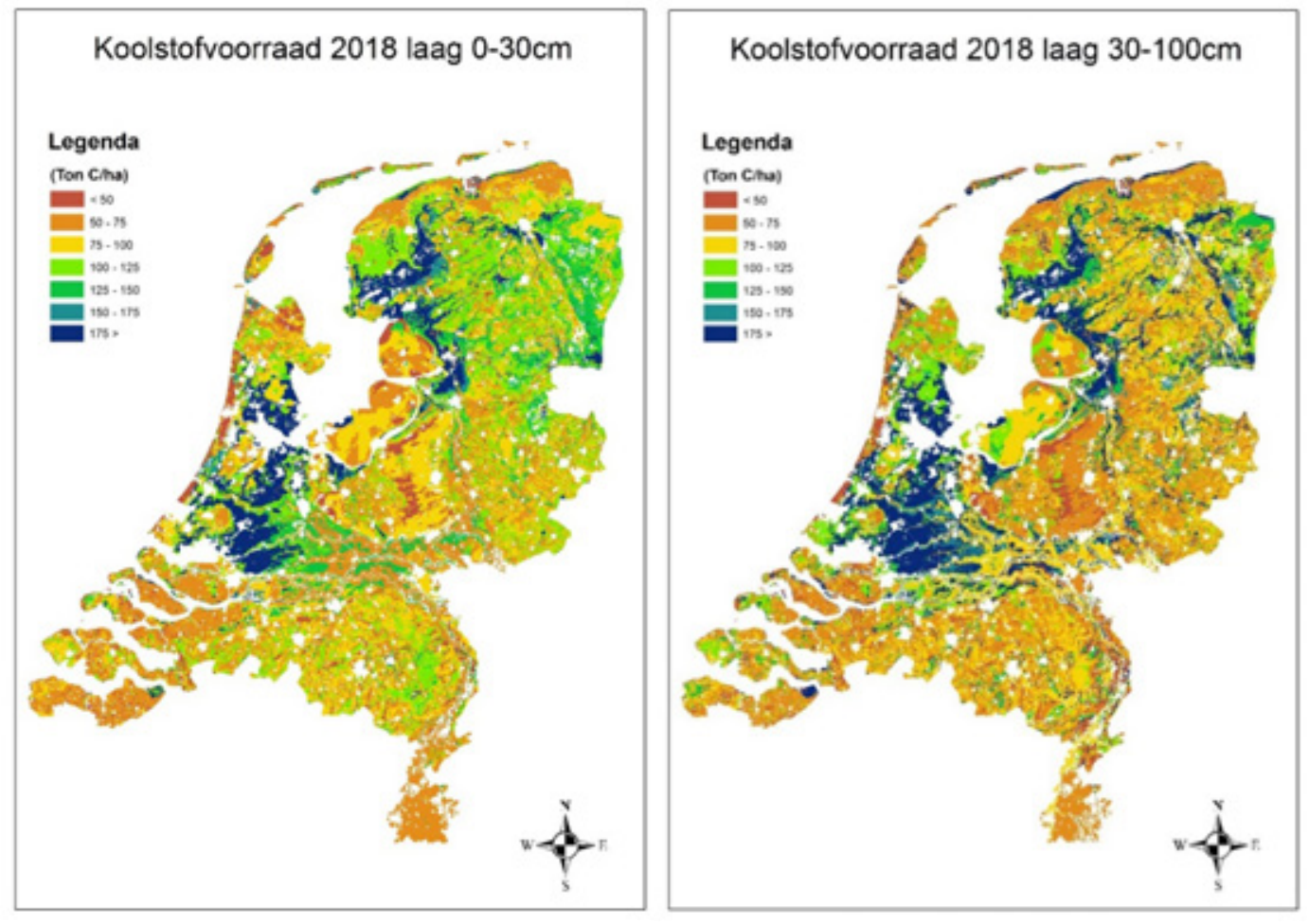

Figuur 10 Koolstofvoorraden in de Nederlandse bodem in 2018 voor de lagen 0-30 cm (links) en voor de laag 30-100 cm (rechts), berekend op basis van de Landelijke Steekproef Kaarteenheden.

De analyses tonen aan dat het gehalte aan organische stof en daardoor de voorraad aan organische stof is afgenomen in de Nederlandse bodem. Opgemerkt moet worden dat het maaiveld als referentieniveau is gehanteerd, waardoor een afname van de koolstofvoorraad niet is vast te stellen in gronden waarin veen- en moerige lagen zowel twintig jaar geleden als nu tot dieper dan $1 \mathrm{~m}$ beneden maaiveld doorlopen.

Terwijl een uitgebreide dataset aan zeer waardevolle meetgegevens is verzameld en deze ook is geanalyseerd met de bovenstaande gegevens als resultaat, resteert nog een aantal vragen met betrekking tot landgebruik, steekproef, dichtheid en koolstofratio. Antwoorden op deze vragen geven mogelijk een verklaring voor de geanalyseerde verschillen en zorgen daarmee voor duidelijkheid in handelingsperspectief en een goede monitoring in de toekomst.

\section{Indringingsweerstand}

Gezien de landsdekkende meetopzet van de huidige studie is besloten om simultaan met de bemonstering ook indringingsweerstanden van de bodem op alle locaties te meten. De indringingsweerstand is afhankelijk van het vochtgehalte, de opbouw van de bodem (alleen zand of klei of zand op veen), maar ook van de persoon die de metingen uitvoert.

De indringingsweerstand, zoals gemeten met de penetrologger, is een maat voor de weerstand die wortels ondervinden tijdens de groei. Vastlegging van $\mathrm{CO}_{2}$ in de bodem gaat deels via planten(wortels). De stelregel is dat wortels bij een indringingsweerstand van meer dan $2 \mathrm{MPa}$ (megapascal) hinder ondervinden, maar nog wel in de bodem kunnen komen. Bij een indringingsweerstand van meer dan $3 \mathrm{MPa}$ is het voor het merendeel van de gewassen niet meer mogelijk om in deze bodem te wortelen.

Figuur 11 toont het verschil in maximale indringingsweerstanden in de laag $0-60 \mathrm{~cm}$ en de laag $60-80 \mathrm{~cm}$ bij een indeling in de zes bodemtypen. Als de maximale indringingsweerstand tussen 0 en $60 \mathrm{~cm}$ groter is dan de maximale indringingsweerstand tussen 60 en $80 \mathrm{~cm}$, dan kan dit duiden op verdichting wanneer beide lagen uit hetzelfde moedermateriaal bestaan. Figuur 11 indiceert dat in de minerale gronden (zand, klei, leem) deels significante verdichtingen in de ondergrond kunnen zijn opgetreden onder akkerland en grasland. Dit is niet het geval in de moerige en veengronden. 


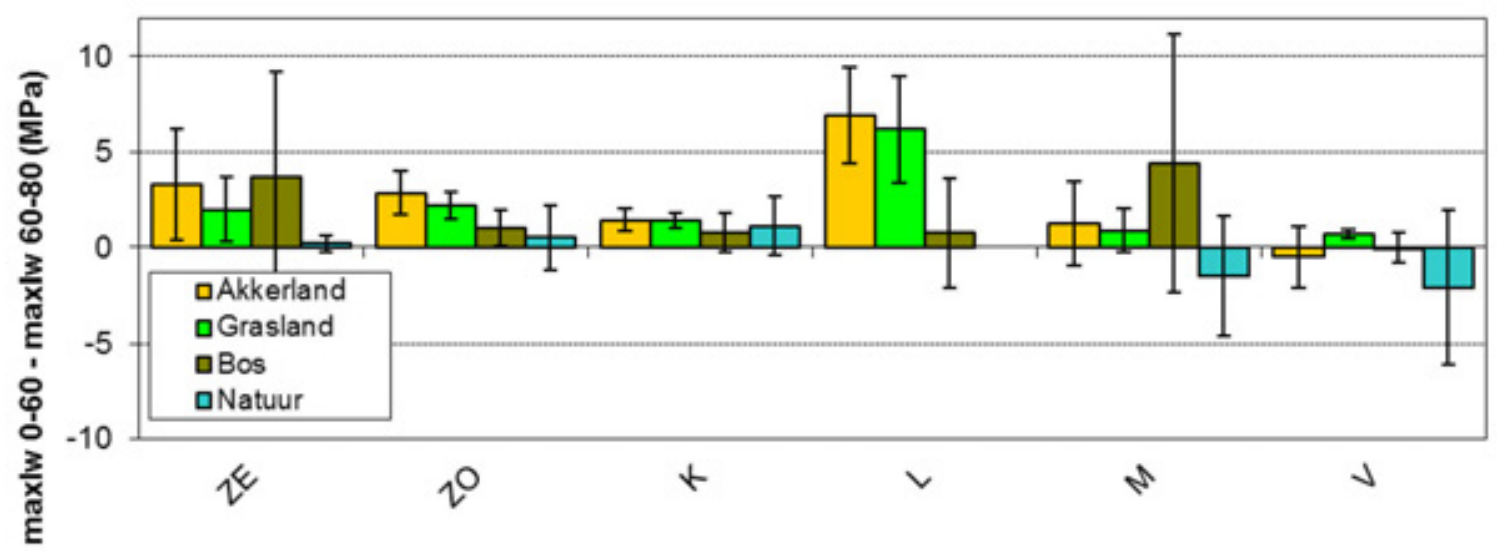

Figuur 11 Gemiddeld verschil tussen de maximale indringingsweerstand tussen 0 en $60 \mathrm{~cm}$ en de maximale indringingsweerstand tussen 60 en $80 \mathrm{~cm}$ (MPa). Een positief verschil kan duiden op verdichting. De error bars geven het $95 \%$-betrouwbaarheidsinterval aan. Indeling naar landgebruik in 1998.

Figuur 12 toont de mediane diepte waarop een indringingsweerstand van 3 MPa wordt bereikt. Een indringingsweerstand hoger dan $3 \mathrm{MPa}$ wordt als storend voor plantengroei gezien. De mediane diepte waarop deze indringingsweerstand van $3 \mathrm{MPa}$ wordt bereikt, is ongeveer $40 \mathrm{~cm}$ voor alle gronden samen.

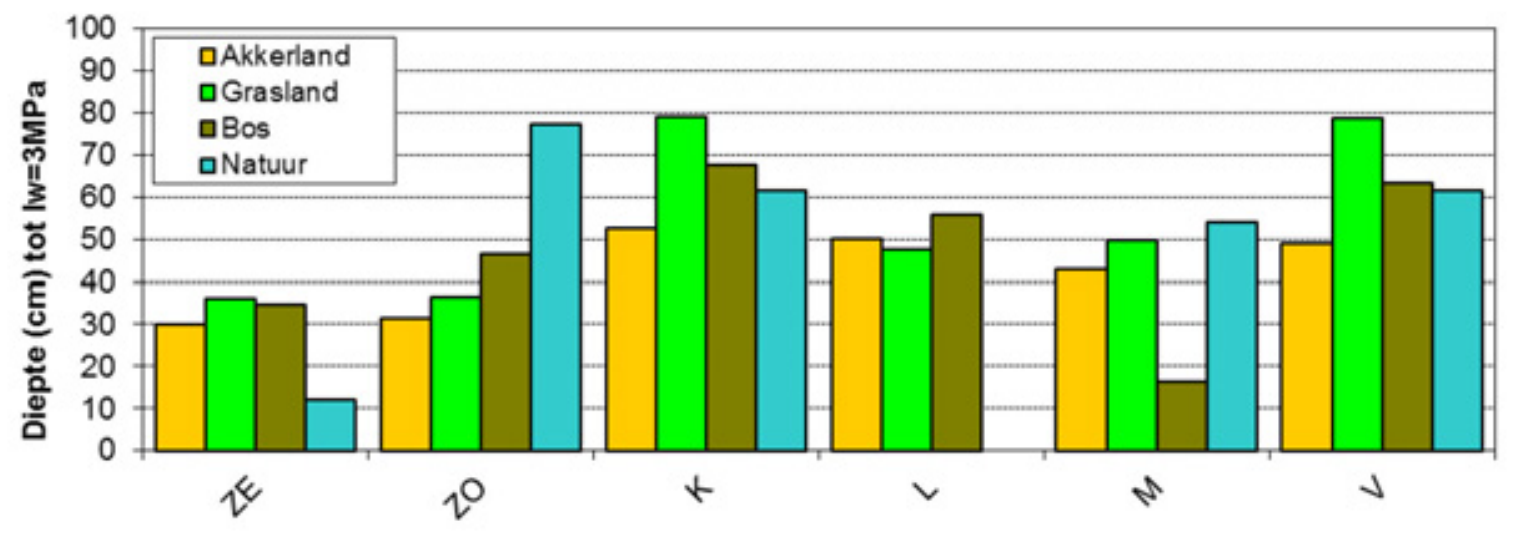

Figuur 12 Mediane diepte tot een indringingsweerstand van 3 MPa (cm). Indeling naar landgebruik in 1998.

Figuur 13 toont de mediane diepte waarop de maximale indringingsweerstand wordt bereikt.

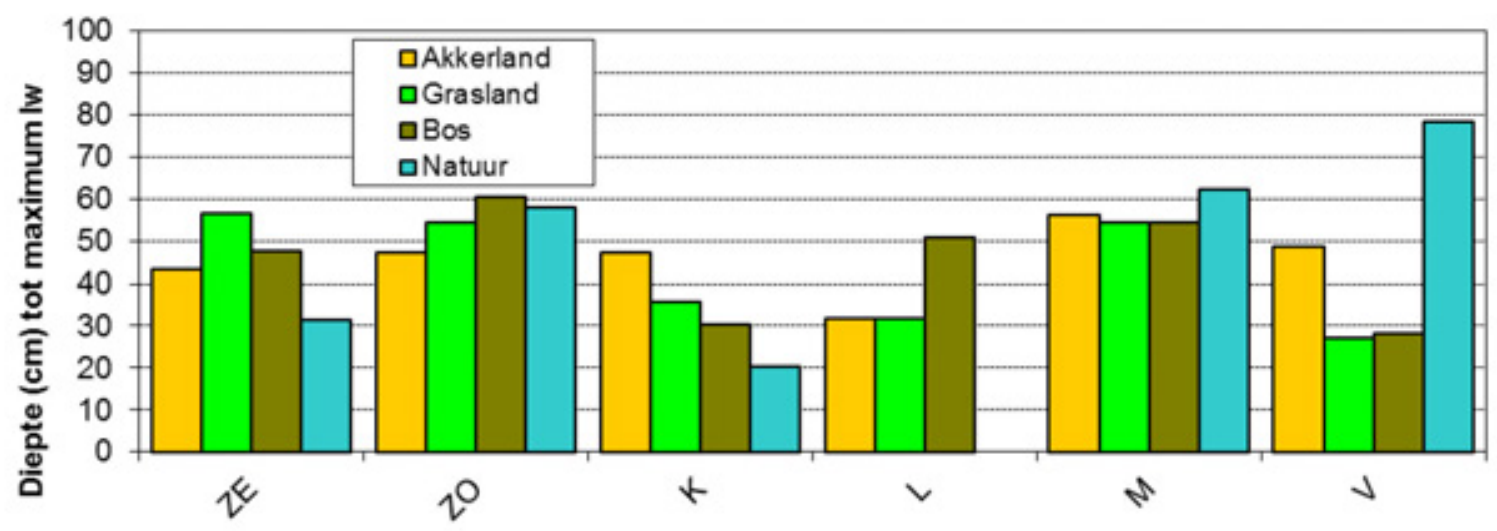

Figuur 13 Mediane diepte tot de maximale indringingsweerstand (cm). Indeling naar landgebruik in 1998. 
Figuur 14 geeft een ruimtelijk beeld van de diepte waarop de indringingsweerstand groter is dan $3 \mathrm{MPa}$. Bij de veengronden wordt de indringingsweerstand van 3Mpa niet in alle gevallen bereikt binnen $80 \mathrm{~cm}$.

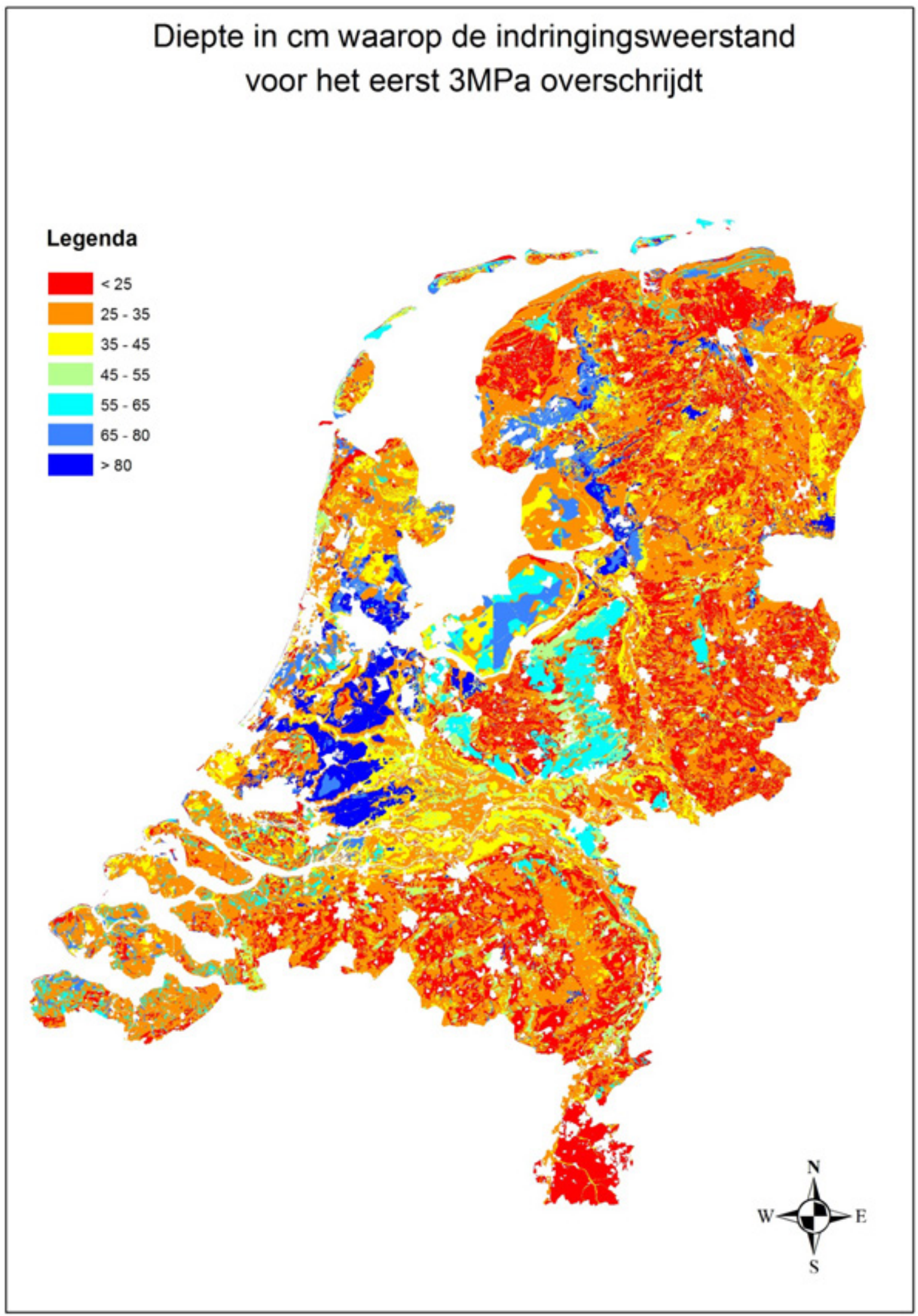

Figuur 14 Diepte waarop een indringingsweerstand van 3 MPa wordt bereikt. 


\section{Aandachtspunten en aanbevelingen}

De resultaten geven de huidige gehalten aan organische stof, dichtheden en koolstofvoorraden in de Nederlandse bodem weer en de veranderingen hierin ten opzichte van twintig jaar geleden. De resultaten van deze meetcampagne bieden een goede uitgangssituatie voor toekomstige monitoring voor de post-2020-LULUCF-rapportage. De resultaten die tot nu toe zijn verkregen, roepen echter ook vijf concrete kennisvragen op. Beantwoording van deze vijf vragen is van belang om van het verleden te leren en om toekomstige meetcampagnes in de periode 2020-2030 nog doelmatiger en efficiënter uit te voeren. Hiermee wordt het ministerie van LNV in staat gesteld om de impact van klimaatslim landgebruik en de bijdrage aan de $\mathrm{CO}_{2}$-reductiedoelstelling vanaf 2018 te monitoren.

Het betreft de volgende kennisvragen:

- Wat is de invloed van veranderend landgebruik? Op landelijke schaal kon geen verandering van gehalten aan organische stof in de Nederlandse bodem worden aangetoond, maar wel een verandering van de koolstofvoorraad (Tabel 2). Voor de 24 combinaties van landgebruik en bodemtype waren veranderingen in koolstofvoorraad vaak niet aantoonbaar. In de huidige analyse is echter uitgegaan van het landgebruik zoals dat ten tijde (1994-2001) van de LSK in het veld is waargenomen. Om verandering te verklaren, is het nodig om naast de dichtheden ook de landgebruiksgeschiedenis en het landmanagement in de afgelopen twintig jaar te analyseren. Op basis van veldwaarnemingen is er ook informatie over het landgebruik in 2018. Hieruit zou al een eerste indicatie van de invloed van landgebruik op de koolstofvoorraad in de bodem kunnen worden afgeleid. In de landgebruiksanalyse lijkt een onderscheid zinnig tussen structurele (definitieve) veranderingen in landgebruik (bijvoorbeeld landbouw $\rightarrow$ natuur) en rotaties bij (melkveehouderij)bedrijven tussen gras, maïs en overige akkerbouwgewassen. Deze gegevens zouden kunnen worden afgeleid uit bijvoorbeeld de Basisregistratie Percelen of via Eurofins (MijnPercelen).

- Wat is de invloed van diepe grondbewerking op de koolstofvoorraad? Tot nu toe is een indeling in bodemtypen gebruikt, ongeacht of een bodem diep bewerkt is. Profielen kunnen echter zijn gediepploegd, gemengwoeld, omgekeerd, afgegraven of opgehoogd. Vergraven, zowel ophogen en afgraven als diepe grondbewerking, heeft invloed op de koolstofvoorraad. Intensieve grondbewerking zorgt onder andere voor zuurstofrijke omstandigheden waarbij organische stof oxideert. Kennis over de historie van diepe grondbewerking is dus belangrijk om veranderingen in gehalten aan organische stof en in koolstofvoorraden te kunnen verklaren.

- Wat is de invloed van veranderingen in bodemdichtheid, zoals verdichting? Om het gemeten gehalte aan organische stof om te zetten naar een koolstofvoorraad, wordt vermenigvuldigd met de bodemdichtheid. De resultaten laten een grote variatie aan bodemdichtheden zien en een grote invloed van de dichtheid op de berekende koolstofvoorraad. De dichtheden die in 2018 aan monsters zijn bepaald die met een guts waren gestoken, weken af van de dichtheden die voor de periode 1994-2001 waren berekend met pedotransferfuncties. Het is van belang dat de dichtheid en veranderingen daarin nauwkeurig worden vastgesteld. Mogelijk heeft de droogte van vorig jaar tijdens de bemonstering geleid tot een vertekend beeld in de dichtheid en daarmee in de koolstofvoorraad. Ook kan een rol spelen dat bij de gutsmethode de bodem vanaf maaiveld is bemonsterd, terwijl bij metingen met ringen doorgaans niet vanaf maaiveld, maar dieper wordt bemonsterd. Het is daarom aan te bevelen om terug te keren naar een selectie van veldlocaties om daar opnieuw de dichtheid vast te stellen. Daarnaast dienen de dichtheden die met de gehanteerde gutsmethode zijn bepaald te worden vergeleken met dichtheden die zijn bepaald volgend de gravimetrische methode met $100 \mathrm{cc}-$ ringen en nieuwe meettechnieken, zoals een dichtheidssensor (Bijlage 3).

- Welke koolstofratio moet worden gehanteerd? Momenteel wordt, in de LULUCF-rapportage, een defaultwaarde van 0,5 (koolstofratio) gehanteerd om het gehalte aan organische stof (SOM) om te rekenen naar het koolstofgehalte (SOC). Er wordt ook wel een factor van 0,58 gehanteerd (de zogeheten Van-Bemmelenfactor). De hoogte van de factor heeft uiteraard grote invloed op de berekende koolstofvoorraad. De laboratoriummetingen die uitgevoerd zijn in 2018, laten gemiddeld een hogere ratio dan 0,5 voor Nederland zien. Voor de laag $0-30 \mathrm{~cm}$ is de ratio gemiddeld 0,54 en voor de laag $30-100 \mathrm{~cm}$ is de ratio 0,51 . Hierdoor is er direct invloed op het berekende koolstofgehalte. Uit nadere analyses blijkt dat, door de grote variatie, de huidige koolstofratio eigenlijk niet algemeen toepasbaar is voor Nederlandse bodems en dat verder onderzoek nodig is. De vraag is of we op basis 
van de huidige laboratoriummetingen wel of niet kunnen afwijken van de huidige defaultwaarde van 0,5 die momenteel voor de LULUCF-rapportage wordt gehanteerd.

- Met welke meetinspanning moet de monitoring worden voortgezet? Om een landsdekkend beeld van de koolstofvoorraden in de bodem te kunnen bepalen, is uitbreiding van de steekproef 2018 nodig. Door bijvoorbeeld bebouwing zijn er meetpunten vervallen. Daarnaast kan het noodzakelijk zijn om bij bepaalde combinaties van landgebruik en bodemtype de steekproef uit te breiden voor een nauwkeuriger schatting van gehalten aan organische stof, koolstofvoorraden en veranderingen daarin. Door de serie meetpunten up-to-date te maken kan een nauwkeurige, nieuwe bepaling van de koolstofvoorraad in de periode 2020-2030 plaatsvinden die kan worden vergeleken met de opnames in 1998 en 2018.

Nabij-infrarood-reflectie (NIR) is een steeds gangbaardere techniek om koolstof in de bodem te meten. In 2018 zijn naast de klassieke data van alle monsterpunten (gebruikt voor de vergelijking 1998) ook NIR-data beschikbaar. Deze datasets lenen zich voor een vergelijking tussen klassiek en NIR, zodat in de toekomst NIR-data gebruikt kunnen worden voor monitoring van de koolstofvoorraden in de bodem. Naast NIR wordt ook mid-infrarode reflectie (MIR) verder ontwikkeld en toegepast. Vorig jaar is een MIR-apparaat aangeschaft. Het is aan te bevelen om zowel NIR als MIR te vergelijken met de klassieke methode qua nauwkeurigheid, toepasbaarheid en betaalbaarheid (Bijlage 3). 


\section{$1 \quad$ Inleiding}

\subsection{Achtergrond}

Met het Klimaatverdrag van Parijs en het Europese klimaatbeleid om ook emissies en vastlegging van koolstof in de bodem mee te laten tellen voor de klimaatdoelstelling, is het belang van het monitoren van de hoeveelheid koolstof in de bodem toegenomen. Het kabinet wil emissies uit de bodem door landgebruik verminderen en vastlegging stimuleren. Het ministerie van LNV heeft de opgave om een reductie van 3,5 Mton $\mathrm{CO}_{2}$-equivalent te realiseren in 2030 boven bestaand beleid. Het ministerie van LNV heeft vooruitlopend op de af te spreken klimaatakkoorden geld uit de klimaatenvelop beschikbaar gesteld voor een project ter vaststelling van de verandering van de koolstofvoorraad in de bodem van Nederland in of rond 2020.

De koolstofvoorraad in de bodem van Nederland in circa 1998 is bepaald aan de hand van bemonsteringgegevens van 1392 locaties van de Landelijke Steekproef Kaarteenheden (LSK). De koolstofvoorraden die hieruit zijn bepaald voor combinaties van landgebruik en bodemtype worden gebruikt in de systematiek voor de rapportage van emissies (Emissieregistratie) en vastlegging voor de LULUCF-sector (LULUCF is een acroniem voor 'Land use, land-use change and forestry', ofwel de sectoren landgebruik en bosbouw). Deze momentopname reflecteert de koolstofvoorraad zoals deze was gedurende de opname van de LSK, van ongeveer 1994 tot 2001, dus circa 1998. In 2018 gaf het Ministerie van LNV opdracht om de dataset te actualiseren met het oog op komende klimaatrapportages (2020-2030). Met dit doel is in 2018 een nieuwe meetcampagne uitgevoerd en de resultaten hiervan zijn gebruikt om de verandering in de koolstofvoorraad in de bodem van Nederland te berekenen over de periode 1998-2018. Voor de meetcampagne is een zorgvuldig bemonsterplan opgesteld, zijn de bemonsteraars getraind en is een herhaling uitgevoerd van de meting van gehalten aan organische stof in de Nederlandse bodems zoals die plaatsvond in 1998. In de 2018 -meetcampagne is $85 \%$ van alle punten bemonsterd die ook in 1998 zijn bemonsterd.

\subsection{Doel}

Het doel van dit project is om de actuele koolstofvoorraad in de bodem van Nederland te bepalen en te vergelijken met de koolstofvoorraad in de periode 1994-2001. Dit gebeurt op basis van bepalingen van het gehalten aan organische stof, koolstofgehalte van de bodem en bulkdichtheid voor circa 1300 locaties uit de Landelijke Steekproef Kaarteenheden (LSK).

\subsection{Opzet rapport}

Hoofdstuk 2 beschrijft de aanpak van de bemonstering, laboratoriumanalyse en de verwerking van de data om tot de koolstofvoorraad in de bodem van Nederland te komen. Hoofdstuk 3 geeft de resultaten, waarbij in paragraaf 3.1 een eerste analyse van de metingen is weergegeven. De actuele koolstofvoorraad wordt in paragraaf 3.2 behandeld. In paragraaf 3.3 en 3.4 worden de resultaten van de verandering in de koolstofvoorraad beschreven. Hierbij is onderscheid gemaakt naar grondsoort en landgebruikstype. Paragraaf 3.5 presenteert de resultaten die zijn verkregen door het meten van de indringingsweerstand met als doel verdichting vast te stellen. Hoofdstuk 4 sluit af met een discussie over variabelen die mogelijk de verandering in de koolstofvoorraad kunnen verklaren en met een aantal kennisvragen die beantwoording behoeven bij voortzetting van monitoring van de koolstofvoorraad in de Nederlandse bodem. 


\section{Aanpak}

\subsection{Bemonstering, laboratoriumanalyses}

De Landelijke Steekproef Kaarteenheden (LSK) startte in 1988, onder meer om de nauwkeurigheid van de bodemkaart van Nederland, schaal 1 : 50.000 te bepalen en om de inhoud van kaarteenheden kwantitatief te beschrijven. De LSK bevat 1392 locaties, die volgens een gestratificeerde, enkelvoudige aselecte steekproef zijn geselecteerd (Finke et al., 2001). Min of meer uniforme deelgebieden (strata) zijn onderscheiden op basis van bodemtype en grondwatertrap volgens de Bodemkaart van Nederland, schaal 1 : 50.000 (Figuur 15). In totaal zijn 96 deelgebieden onderscheiden en in elk hiervan zijn steekproeflocaties geloot. Op deze wijze is zowel een goede spreiding over verschillende bodemkundige en hydrologische situaties als een goede ruimtelijke spreiding verkregen.
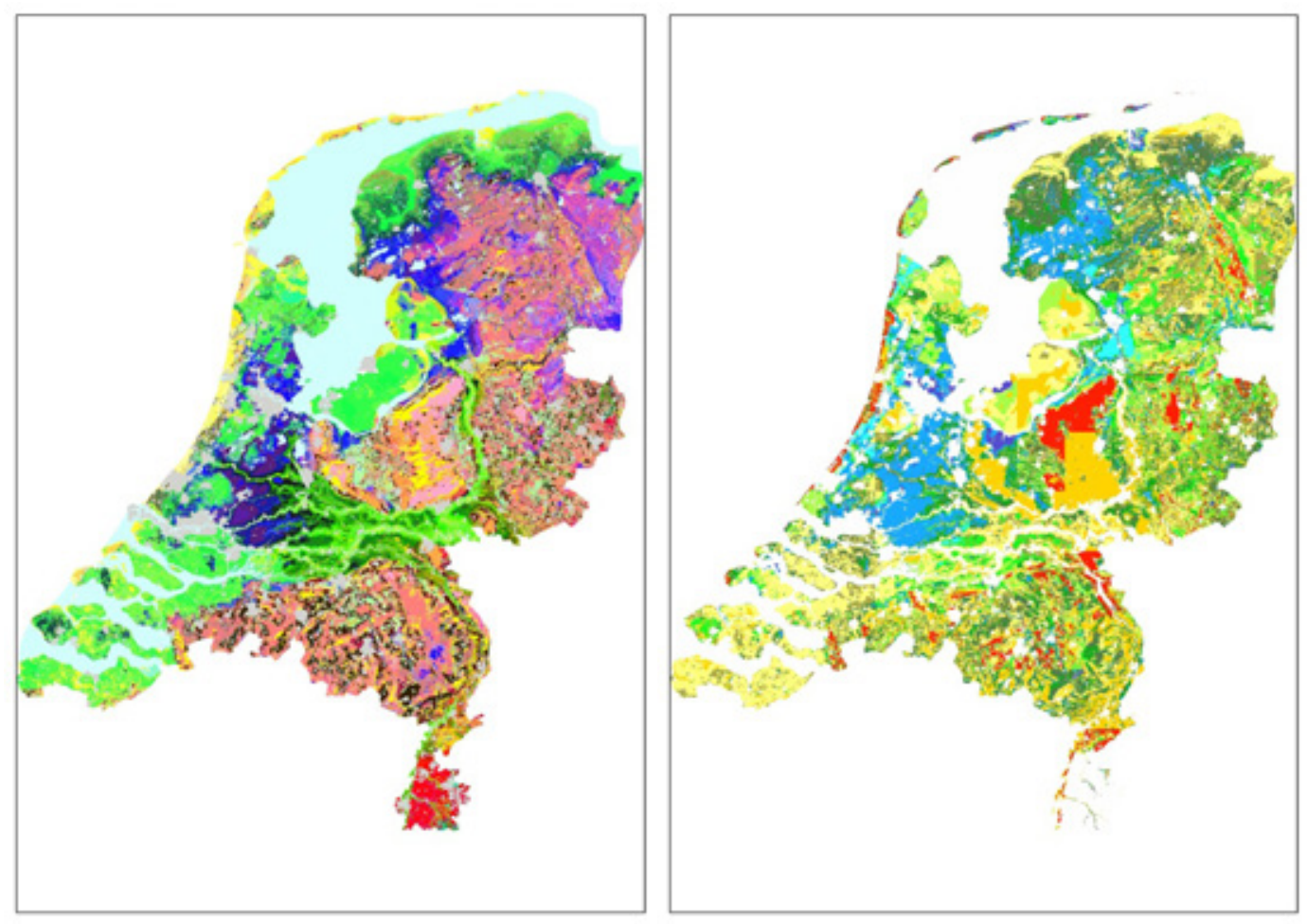

Figuur 15 Links de Bodemkaart en rechts de Grondwatertrappenkaart van Nederland, schaal 1 : 50.000, als basis voor de LSK.

De indeling op basis van grondwatertrap en bodemtype zorgt ervoor dat de deelgebieden niet aaneengesloten liggen, maar ruimtelijk zijn verspreid. Figuur 16 geeft als voorbeeld de ligging van deelgebied Hn21-VI in rood weer. 


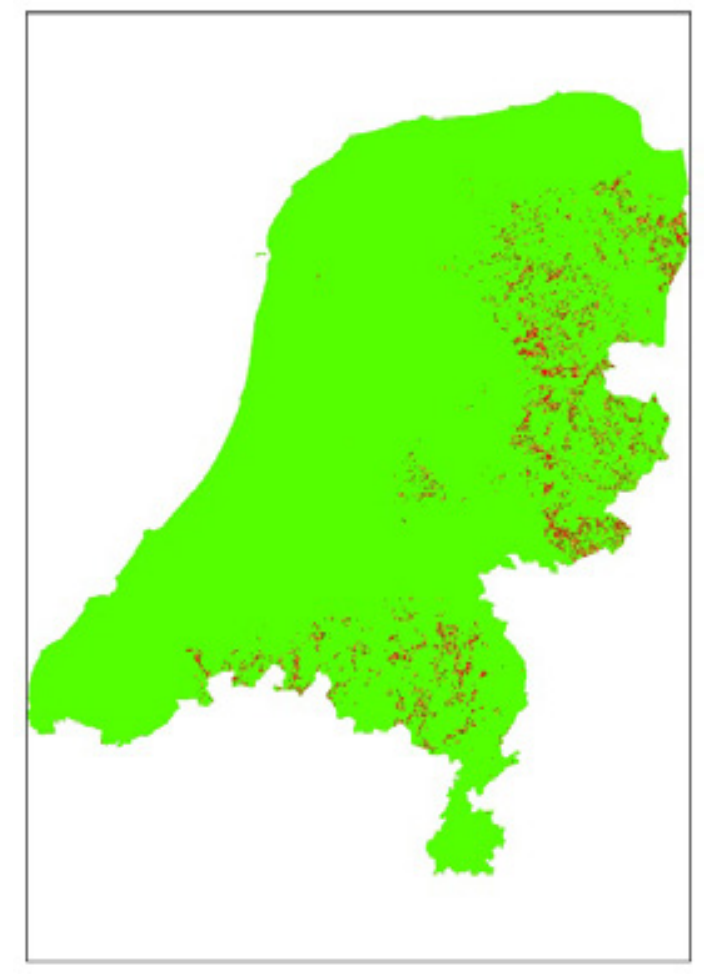

Figuur 16 Ligging deelgebied Hn21-VI (rood = deelgebied, groen = overige gebieden).

De opzet van de LSK maakt het mogelijk om de koolstofvoorraad in de Nederlandse bodem te berekenen, zoals deze wordt gerapporteerd aan de UNFCCC sinds circa 2000, om veranderingen in voorraden te berekenen en om kaarten te maken die een ruimtelijke variatie weergeven van voorraden en veranderingen daarin.

Om de actuele koolstofvoorraad te kunnen schatten, moesten de locaties van de LSK opnieuw worden bezocht en bemonsterd. Het was de verwachting dat 10 à $20 \%$ van de 1392 locaties niet opnieuw zouden kunnen worden bemonsterd als gevolg van recente bebouwing en/of ontoegankelijkheid.

$\mathrm{Na}$ het opstellen van een uitgebreid bemonsteringsprotocol (Bijlage 1) en drie dagen training van 30 bemonsteraars van Eurofins heeft het ministerie van LNV een 'go' gegeven om te starten met de bemonstering van de 1392 locaties. Deze bemonstering is in de periode oktober-december 2018 door Eurofins uitgevoerd. Na één week bemonsteren is besloten dat het efficiënter werkt om vooraf een brief naar de grondeigenaren te sturen. Deze brief is in overleg met het ministerie van LNV opgesteld. Twee eigenaren reageerden hierop door geen toestemming te verlenen, terwijl 69 eigenaren graag meer informatie over hun perceel wilden ontvangen. De bemonstering heeft enkele weken vertraging opgelopen doordat in het begin niet al het materieel (een speciale guts en hamer) beschikbaar was, de doorlooptijd voor vergunningen varieerde van enkele dagen tot weken en doordat een hoofdwater- en een gasleiding tijdens de bemonstering zijn geraakt, ondanks het raadplegen van de beschikbare voorinformatie.

Grondmonsters zijn verzameld door op elke locatie in het midden en daarna in een cirkel eromheen in totaal vijf steken grond te nemen en deze te mengen tot een monster. Dit komt overeen met de methode die gebruikt wordt in de LUCAS Land Use/Land Cover Area Frame Survey (Fernández-Ugalde et al., 2017, zie Bijlage 1 voor details). De vier steken om het middelpunt liggen op $2 \mathrm{~m}$ afstand en in de vier windrichtingen N, Z, O en W (Figuur 17). De bodem wordt over twee dieptes bemonsterd: 0-30 cm en 30-100 cm. Om de volledige diepte te bemonsteren, wordt gebruikgemaakt van een steekguts, zoals te zien is in Figuur 18. De guts heeft een lengte van $100 \mathrm{~cm}$ en een diameter van $3 \mathrm{~cm}$. De inhoud, tot de snijrand, is $4,44 \mathrm{~cm}^{3}$ per $\mathrm{cm}$. Door het bemonsterde volume vast te stellen, wordt na drogen van de grond ook de volumieke dichtheid berekend. 


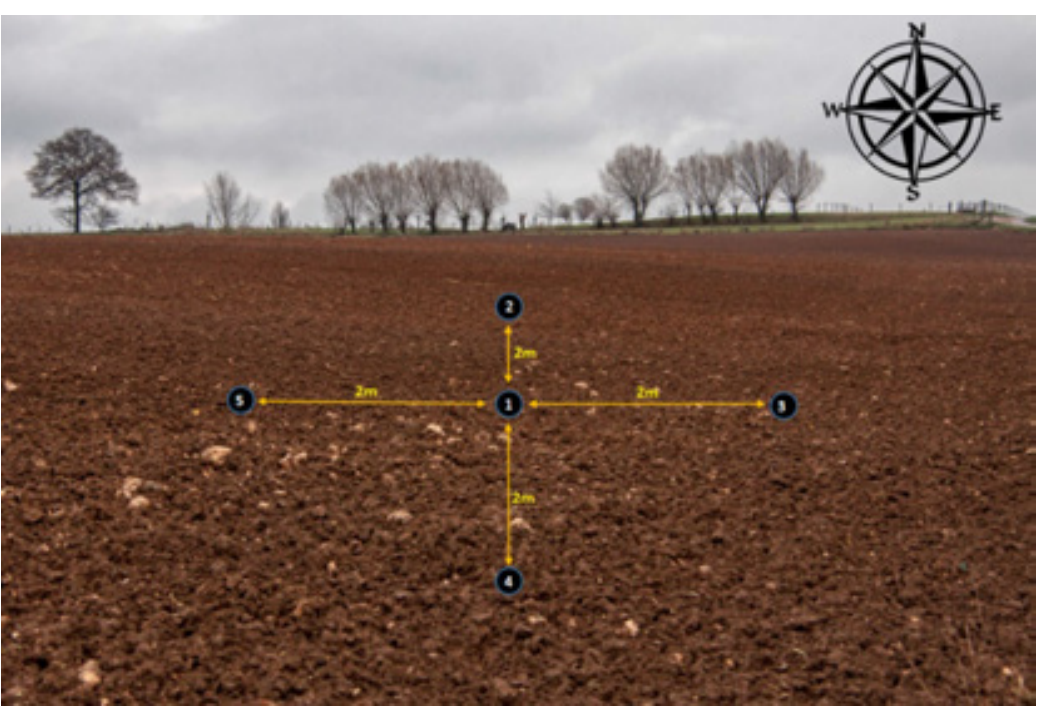

Figuur 17 Bemonsteringsmethode.

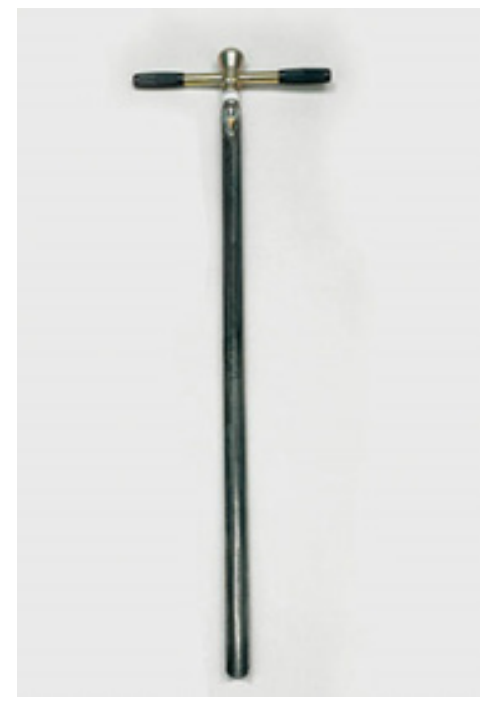

Figuur 18 Steekguts.

De monsters worden vervolgens in het laboratorium geanalyseerd op onder meer het gehalte aan organische stof, gehalte aan organische stof elementair, koolstofgehalte elementair en totaalgehalte stikstof elementair.

Uiteindelijk konden op 1152 van de 1392 locaties monsters worden genomen. Er vielen dus 240 locaties af, dit is circa $17 \%$. Punten zijn afgevallen doordat grondeigenaren geen toestemming gaven om te bemonsteren, de eigenaar onbekend was of omdat er bebouwing of verharding was aangetroffen. Figuur 19 geeft weer waar de locaties liggen die bemonsterd zijn (linkerfiguur) en welke locaties zijn afgevallen (rechterfiguur). Relatief veel locaties die zijn afgevallen, liggen rondom de grotere steden en in het bosgebied rond de Veluwe. 


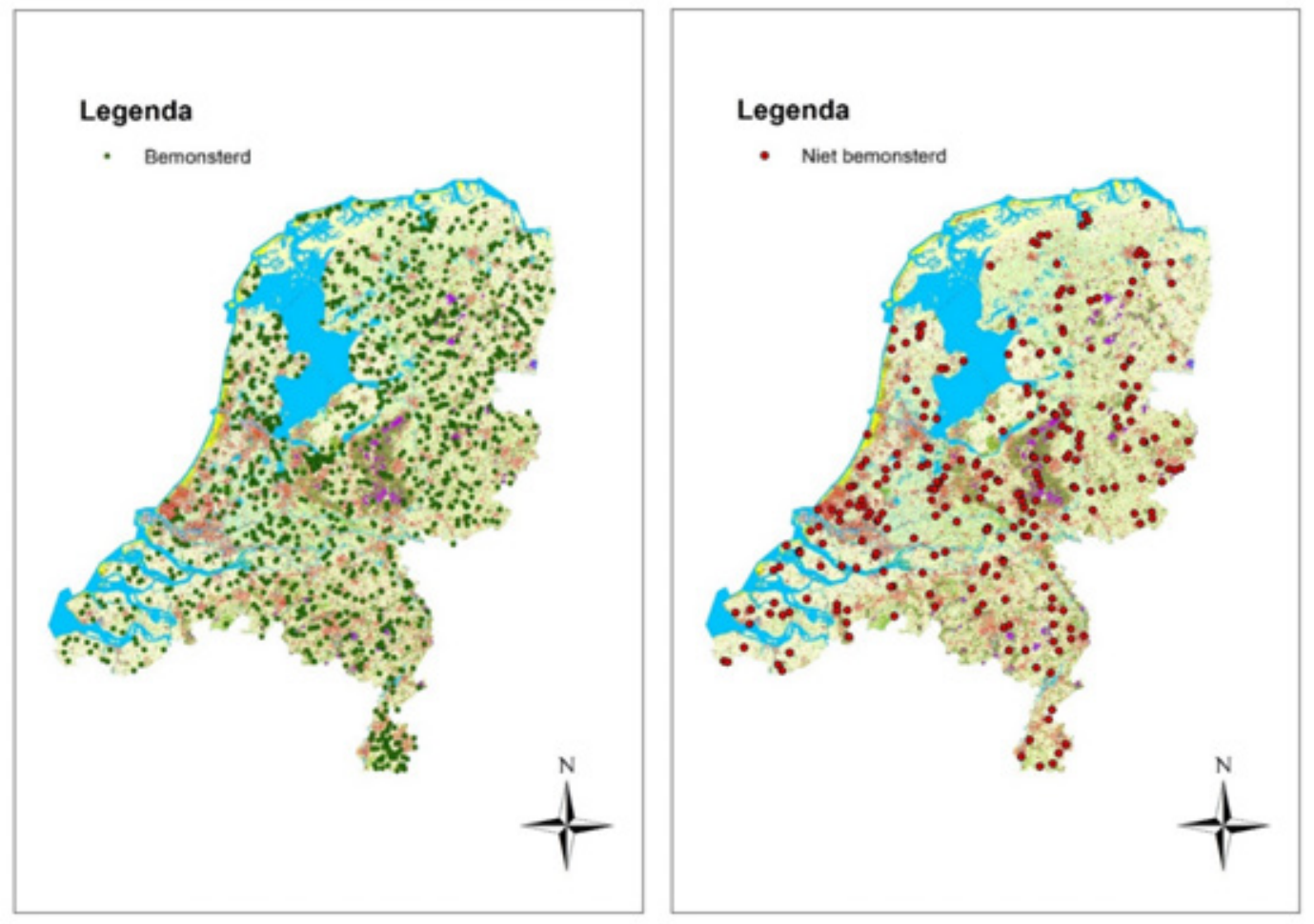

Figuur 19 LSK-locaties die wel (links) en die niet bemonsterd zijn (rechts).

Bij de bemonstering in het veld en bij de laboratoriumanalyses (Bijlage 4) is gewerkt met protocollen die beschrijven hoe de locatie wordt vastgesteld en gevonden, hoe de bemonstering plaatsvindt, hoe de monsters worden meegenomen en aangeboden aan het laboratorium van Eurofins en hoe de voorbewerking van monsters, de menging en de grondanalyses plaatsvinden (Bijlage 1).

\subsection{Dichtheidsmetingen}

Ten tijde van de LSK (1994-2001) zijn geen dichtheden gemeten. Om voorraden aan organische stof en koolstof te kunnen berekenen, zijn daarom dichtheden afgeleid uit pedotransferfuncties (Kuikman et al., 2003; Wösten et al., 2001). In 2018 zijn dichtheden gemeten aan volumemonsters die zijn gestoken met een guts, volgens de methode van Visschers en Marsman (1991).

\subsection{Dataverwerking}

\subsubsection{Analyse op landelijk niveau}

Het steekproefontwerp van de Landelijke Steekproef Kaarteenheden (LSK) maakt het mogelijk dat bij het schatten van de actuele koolstofvoorraad in de bodem van Nederland en de verandering in koolstofvoorraad ook de standaardfout kan worden berekend. De standaardfout is een maat voor de nauwkeurigheid van de geschatte voorraden en veranderingen daarin. Dit maakt het mogelijk om te concluderen over veranderingen in termen van significantie. Een deelgebied dient minstens één bemonsteringslocatie te bevatten om een koolstofvoorraad voor dit gebied te schatten en minstens twee bemonsteringslocaties om ook een standaardfout hiervan te kunnen bepalen. Daarom vielen bij de verwerking van de data nog eens negen locaties af die als enige in een deelgebied lagen, waardoor het aantal locaties waarop de schatting van de koolstofvoorraad is gebaseerd 1143 bedraagt.

Om de koolstofvoorraad in de bodem te bepalen en te vergelijken met de koolstofvoorraad in de periode 1994-2001, is de methodiek die in 2018 is gevolgd zo veel mogelijk afgestemd op die tussen 1994 en 2001. Toch waren verschillen onvermijdelijk, bijvoorbeeld doordat in 2018 vernieuwde 
apparatuur is gebruikt en de bemonsteraars, in tegenstelling tot 1994-2001, geen bodemkundige opleiding hebben en dus geen horizonten kunnen onderscheiden. Tabel 4 geeft de verschillen in methodiek weer voor de variabelen die van belang zijn bij de schatting van de koolstofvoorraad.

Tabel 4 Methodiekverschillen voorraadbepaling heden en verleden.

\begin{tabular}{|c|c|c|}
\hline Variabele & 1994-2001 & 2018-2019 \\
\hline Laagdikte & $\begin{array}{l}\text { 0- } 100 \mathrm{~cm} \text { (soms dieper) met } \\
\text { horizontsplitsing uitgevoerd met boor }\end{array}$ & $\begin{array}{l}0-30 \mathrm{~cm} \text { en } 30-100 \mathrm{~cm} \text { uitgevoerd met } \\
\text { guts }\end{array}$ \\
\hline Dichtheid & $\begin{array}{l}\text { Berekend per horizont met } \\
\text { vertaalfunctie (pedotransferfunctie) uit } \\
\text { gemeten en geschatte textuur }\end{array}$ & Bepaald via volume guts \\
\hline $\begin{array}{l}\text { Lutumgehalte voor correctie van het } \\
\text { gehalte aan organische stof bij grond } \\
\text { met hoog lutumgehalte }\end{array}$ & $\begin{array}{l}\text { Lutumgehalte bepaald met } \\
\text { pipetmethode }\end{array}$ & Lutumgehalte bepaald met NIR \\
\hline Koolstofgehalte & Niet bepaald & $\begin{array}{l}\text { Gehalte C-elementair in het } \\
\text { laboratorium bepaald }\end{array}$ \\
\hline Locatie ( $x$ - en $y$-coördinaat) & $\begin{array}{l}\text { Locatie in het veld bepaald met } \\
\text { Topografische Kaart 1: } 25.000\end{array}$ & $\begin{array}{l}\text { Locatie in het veld bepaald met gps met } \\
5 \text { meter nauwkeurigheid }\end{array}$ \\
\hline Aantal & 1392 locaties & 1152 locaties \\
\hline Doorlooptijd veldwerk & 6 jaar & 5 maanden \\
\hline Aantal veldmedewerkers & 2 & \pm 20 \\
\hline
\end{tabular}

\section{Voorraad organische stof en koolstof}

De voorraad aan organische stof in de bodem van Nederland wordt berekend door:

- van alle bemonsterde locaties het gehalte aan organische stof te vermenigvuldigen met de dichtheid en de laagdikte tot een hoeveelheid organische stof per hectare;

- per deelgebied de voorraad te berekenen door de organische stofvoorraad per hectare van alle punten in het deelgebied te middelen en dit gemiddelde te vermenigvuldigen met de oppervlakte van het deelgebied;

- de voorraden van de deelgebieden bij elkaar op te tellen tot een totaal voor het doelgebied van de LSK: 2.870 .671 ha;

- voor de berekening van de voorraad koolstof wordt een ratio koolstof: organische stof gehanteerd van 0,5 .

De berekening van de voorraad is beschreven door Kuikman et al. (2003). Het gezamenlijke oppervlak van de deelgebieden van de LSK, 2.870.671 ha, komt overeen met de oppervlakte van de bodemkaart van Nederland schaal 1: 50 000, exclusief alle bijzondere onderscheidingen zoals water, wegen en bebouwd terrein.

Binnen een deelgebied worden de meetwaarden van gelote en bemonsterde punten rekenkundig gemiddeld. Voor het vaststellen van het landelijke gemiddelde beeld zijn deze deelgebiedgemiddelden gewogen naar het oppervlakte van het deelgebied. Dit is conform de verwerkingsprocedure voor LSKdata die is beschreven door Finke et al. (2001).

Zoals genoemd, is de LSK een gestratificeerde steekproef die dus eigenlijk uit meerdere enkelvoudige steekproeven bestaat voor een aantal deelgebieden (strata) van de Bodem- en Gt-kaart van Nederland, schaal $1: 50.000$. Voor elk deelgebied is een gemiddelde voorraad berekend en vervolgens zijn deze gemiddelden per deelgebied weergegeven op een kaart, zodat een landelijk beeld van de ruimtelijke spreiding van voorraden ontstaat. 


\subsubsection{Analyse voor interessegebieden}

Om inzicht te krijgen in gehalten aan organische stof, koolstofvoorraden en veranderingen daarin in gebieden met een specifieke grondsoort of een specifieke vorm van landgebruik, zijn naast landelijke analyses ook analyses voor interessegebieden uitgevoerd. Interessegebieden zijn op twee verschillende manieren onderscheiden:

1. Op basis van de indeling in deelgebieden (stratificatie) die bij de LSK is gehanteerd. Deze indeling is gemaakt aan de hand van de Bodemkaart van Nederland, schaal $1: 50.000$. Hiermee kunnen uitspraken worden gedaan voor een bekende oppervlakte, namelijk een deel van de Bodemkaart van Nederland, schaal $1: 50.000$. De bodemkundige opbouw van deze oppervlakte is echter niet exact bekend, omdat de bodemkaart een model is die bij benadering de bodemgesteldheid weergeeft. Een deel van de oppervlakte 'minerale gronden' kan daardoor bijvoorbeeld uit moerige gronden en veengronden bestaan. Dit deel wordt 'onzuiverheid' genoemd. De interessegebieden vallen samen met (clusters van) strata. Schattingen van gemiddelden en totalen zijn gebaseerd op de stratificatie die bij de LSK is gehanteerd, volgens de procedure in Finke et al. (2001, blz. 22-23).

2. Op basis van de bodemkundige profielbeschrijvingen en het waargenomen landgebruik op de locaties van de LSK ten tijde van de opnames tussen 1994 en 2001 . Hiermee is het mogelijk om uitspraken te doen voor bijvoorbeeld een bepaald bodemtype en een bepaalde vorm van landgebruik. De exacte ligging en de oppervlakte hiervan kunnen echter niet worden aangegeven, omdat er immers alleen informatie uit een steekproef over is. De oppervlakte kan echter wel worden geschat. Wij spreken in dit geval van domeinschattingen, dat wil zeggen schattingen voor een bepaald interessedomein. Deze interessedomeinen hoeven niet samen te vallen met (clusters van) strata van de LSK. Domeinschattingen zijn uitgevoerd met de procedure die Finke et al. (2001, blz. 24) geven.

\subsubsection{Indeling in interessegebieden volgens stratificatie van de LSK}

Bijlage 2 geeft aan welke deelgebieden (strata) van de LSK gerekend zijn tot minerale gronden, moerige gronden en veengronden. Bij moerige gronden en veengronden is onderscheid gemaakt naar de diepte waarbinnen moerig materiaal voorkomt: binnen $30 \mathrm{~cm}$ of binnen 30 tot $100 \mathrm{~cm}$. Verder is onderscheid gemaakt tussen deelgebieden die volgens de Bodemkaart van Nederland, schaal 1 : 50.000, uitsluitend uit minerale gronden bestaan en deelgebieden die volgens die kaart naast minerale gronden ook moerige gronden en veengronden kunnen bevatten.

\subsubsection{Indeling in interessegebieden volgens waarnemingen op LSK-locaties}

Figuur 20 toont de verdeling van de meetpunten per landgebruikscategorie volgens de LULUCF-indeling (Lesschen et al., 2012). 


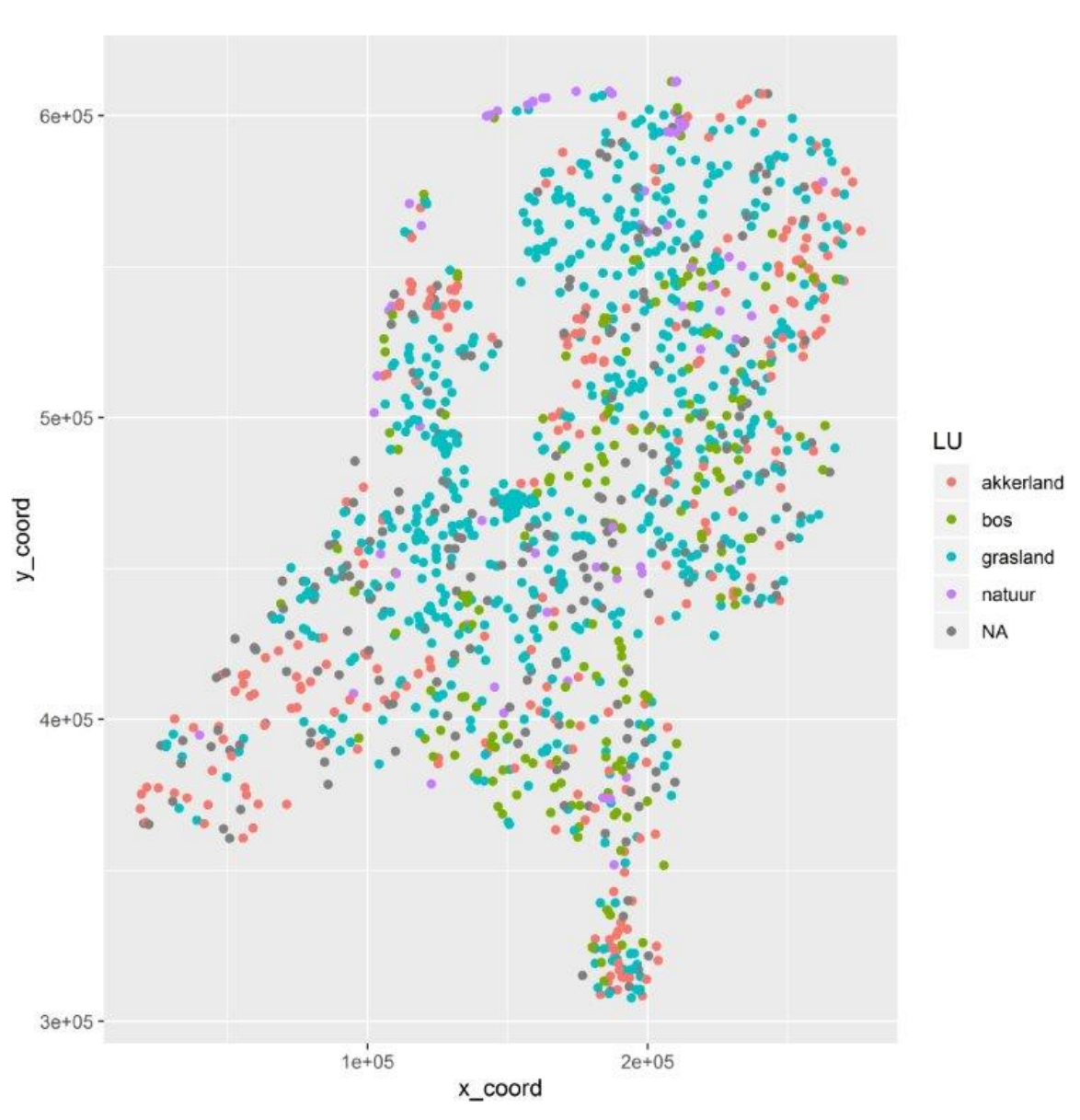

Figuur 20 Meetpunten van de LSK, ingedeeld naar landgebruikscategorie volgens LULUCF (Lesschen et al., 2012). De locaties die in 2018 niet zijn bezocht, zijn aangegeven met NA.

De vier landgebruikscategorieën zijn gecombineerd met twee indelingen naar bodemtype:

1. een fijne indeling in elf bodemtypen (Lesschen et al., 2012). Deze indeling is ontleend aan de legenda van de Bodemkaart van Nederland, schaal 1 : 50.000 en, evenals het systeem van bodemclassificatie dat bij de bodemkartering wordt gehanteerd, pedogenetisch van aard, dus gebaseerd op bodemvorming.

2. een grove indeling in zes bodemtypen, die in samenspraak met het ministerie van LNV is ontworpen voor deze rapportage van koolstofvoorraden en veranderingen daarin. Deze indeling is tot stand gekomen op basis van de volgende vier criteria:

a. gebaseerd op grondsoorten (zand, klei, veen, leem);

b. relevant voor de koolstofvoorraad in de bovenste $30 \mathrm{~cm}$;

c. reductie van het aantal interessegebieden waardoor per interessegebied nauwkeuriger schattingen mogelijk zijn;

d. in combinatie met de landgebruikscategorieën gebieden onderscheidt waaraan een handelingsperspectief kan worden toegekend.

$\mathrm{Bij}$ zand is onderscheid gemaakt tussen gronden met en zonder een eerdlaag van $30 \mathrm{~cm}$ of dikker. Bij klei bleek dit onderscheid niet zinvol, omdat de oppervlakte kleigronden met een eerdlaag van $30 \mathrm{~cm}$ of dikker gering is. Bij veen is onderscheid gemaakt tussen veengronden, met meer dan $40 \mathrm{~cm}$ moerig materiaal binnen $80 \mathrm{~cm}$, en moerige gronden; dit zijn gronden met een moerige laag die dunner is dan $40 \mathrm{~cm}$, maar binnen $40 \mathrm{~cm}$ begint. Samengevat zijn de volgende zes bodemtypen onderscheiden:

1. Zandgronden met een eerdlaag, dikker dan $30 \mathrm{~cm}$

2. Overige zandgronden

3. Kleigronden (inclusief kleibrikgronden en oude kleigronden)

4. Leemgronden (inclusief leembrikgronden)

5. Moerige gronden (inclusief moerige podzolgronden)

6. Veengronden 
Bij deze indeling zijn de oppervlakten (ha) in 1998 van de deelgebieden naar bodem en landgebruik zoals vermeld in Tabel 5.

Tabel 5 Oppervlakten (ha) in 1998 van de deelgebieden naar bodem en landgebruik, geschat op basis van de Landelijke Steekproef Kaarteenheden.

\begin{tabular}{|c|c|c|}
\hline Deelgebied & & Oppervlakte (ha) \\
\hline Bodem & Landgebruik & \\
\hline \multirow[t]{3}{*}{ Zandgronden met een eerdlaag, dikker dan $30 \mathrm{~cm}$} & Akkerland & 97.796 \\
\hline & Bos & 23.466 \\
\hline & Natuur & 2.496 \\
\hline \multirow{3}{*}{ Overige zandgronden } & Grasland & 500.967 \\
\hline & Bos & 318.606 \\
\hline & Natuur & 81.626 \\
\hline Kleigronden & Akkerland & 399.855 \\
\hline \multirow[t]{4}{*}{ Leemgronden } & Akkerland & 17.731 \\
\hline & Grasland & 18.992 \\
\hline & Bos & 11.828 \\
\hline & Natuur & 0 \\
\hline \multirow[t]{4}{*}{ Moerige gronden } & Akkerland & 19.166 \\
\hline & Grasland & 68.648 \\
\hline & Bos & 10.574 \\
\hline & Overige natuur & 7.652 \\
\hline Veengronden & Akkerland & 16.750 \\
\hline
\end{tabular}




\section{Resultaten}

\subsection{Eerste analyse van de metingen}

Figuur 21 geeft een beeld van de veranderingen in gehalten aan organische stof tussen circa 1998 en 2018 op de locaties van de LSK. Afnames komen in het hele land voor, maar lijken het grootst te zijn in gebieden veen- en moerige gronden.
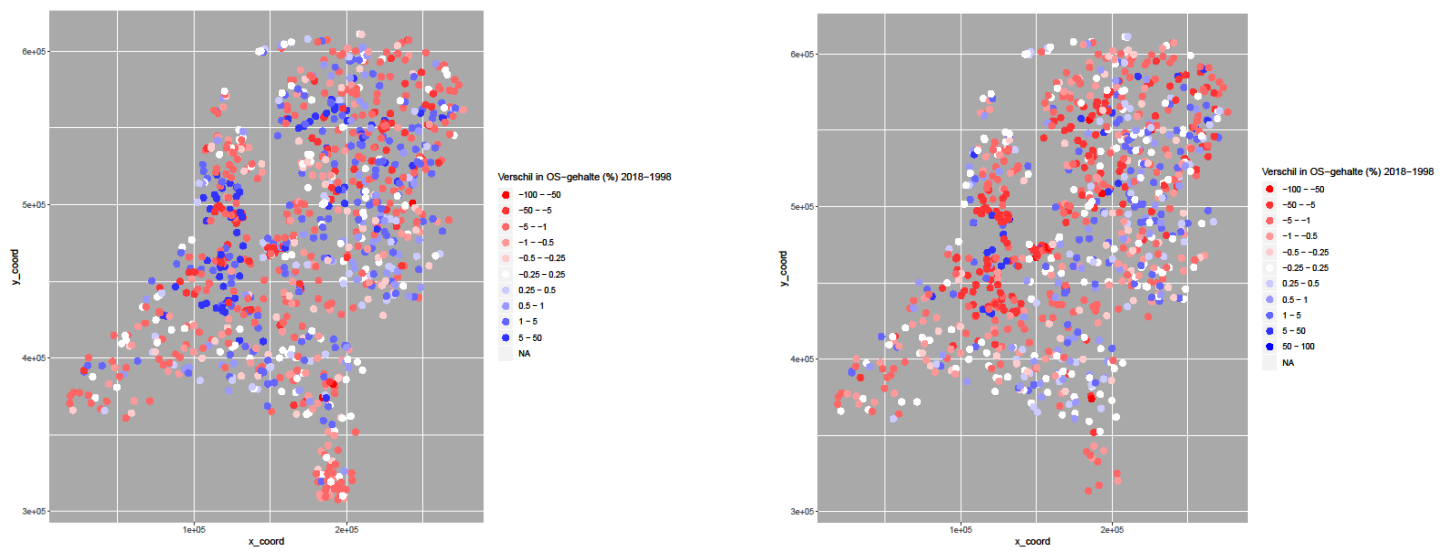

Figuur 21 Ruimtelijk beeld van de verschillen (2018-1998) in gemeten gehalten aan organische stof (\%) voor de laag 0-30 cm (links) en voor de laag 30-100 cm (rechts).

Figuur 22 geeft een beeld van de veranderingen in de voorraad organische stof tussen circa 1998 en 2018. Het verschil met Figuur 21 is dat hier, naast het gehalte aan organische stof, ook de gemeten dichtheid van de grond is verwerkt. Afnames van voorraden organische stof komen verspreid door het land voor. De afnames zijn in de laag van 30 tot $100 \mathrm{~cm}$ groter dan in de laag van 0 tot $30 \mathrm{~cm}$.
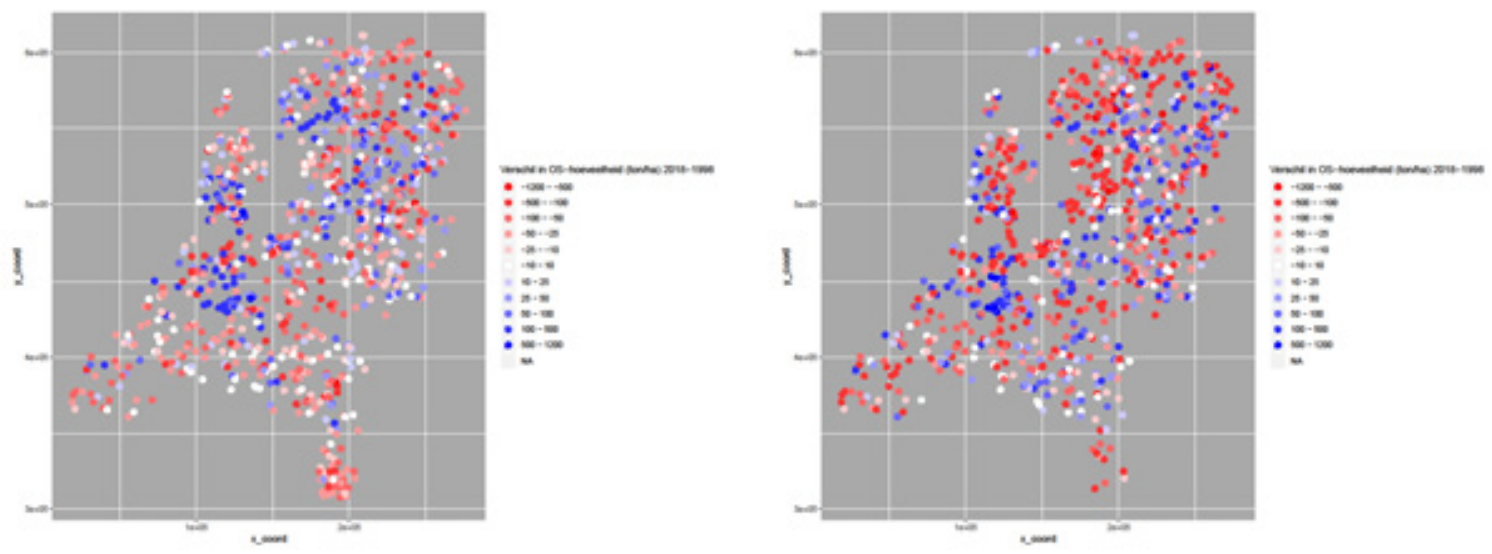

Figuur 22 Ruimtelijk beeld van de verschillen in gemeten voorraden organische stof (ton/ha) voor de laag 0-30 cm (links) en voor de laag 30-100 cm (rechts). 


\subsection{Actuele koolstofvoorraad}

\subsubsection{Actuele koolstofvoorraad}

Op basis van de beschikbare data is een gemiddeld gehalte aan organische stof voor Nederland geschat (Tabel 6) en is met behulp van de gemeten dichtheden de actuele koolstofvoorraad in de bodem van Nederland berekend.

De deelgebieden 1914, 1915, 2006, 2013, 2102 en 2108 zijn buiten beschouwing gelaten, omdat in deze deelgebieden slechts één of helemaal geen waarneming is verricht. Hierdoor konden voor deze deelgebieden geen gemiddelden met standaardfout worden geschat. De gezamenlijke oppervlakte van deze deelgebieden bedraagt 37.512 hectare.

Tabel 6 Geschatte actuele koolstofvoorraad in de bodem (2.870.671 ha) van Nederland 2018-2019 voor alle gronden die zijn bemonsterd (standaardfout tussen haakjes).

\begin{tabular}{lll} 
Variabele & Laag 0-30 cm & Lag 30-1,00 cm \\
Gemiddeld gehalte aan organische stof in Nederland (\%) & $6,43(0,14)$ & $5,11(0,16)$ \\
\hline Voorraad C Nederland (Mton)* & $266,71(3,50)$ & $345,83(6,31)$
\end{tabular}

*Aanname dat $50 \%$ van de organische stof uit koolstof bestaat en op basis van gemeten dichtheden.

Figuur 23 toont de verspreiding van deze koolstofvoorraad over Nederland.

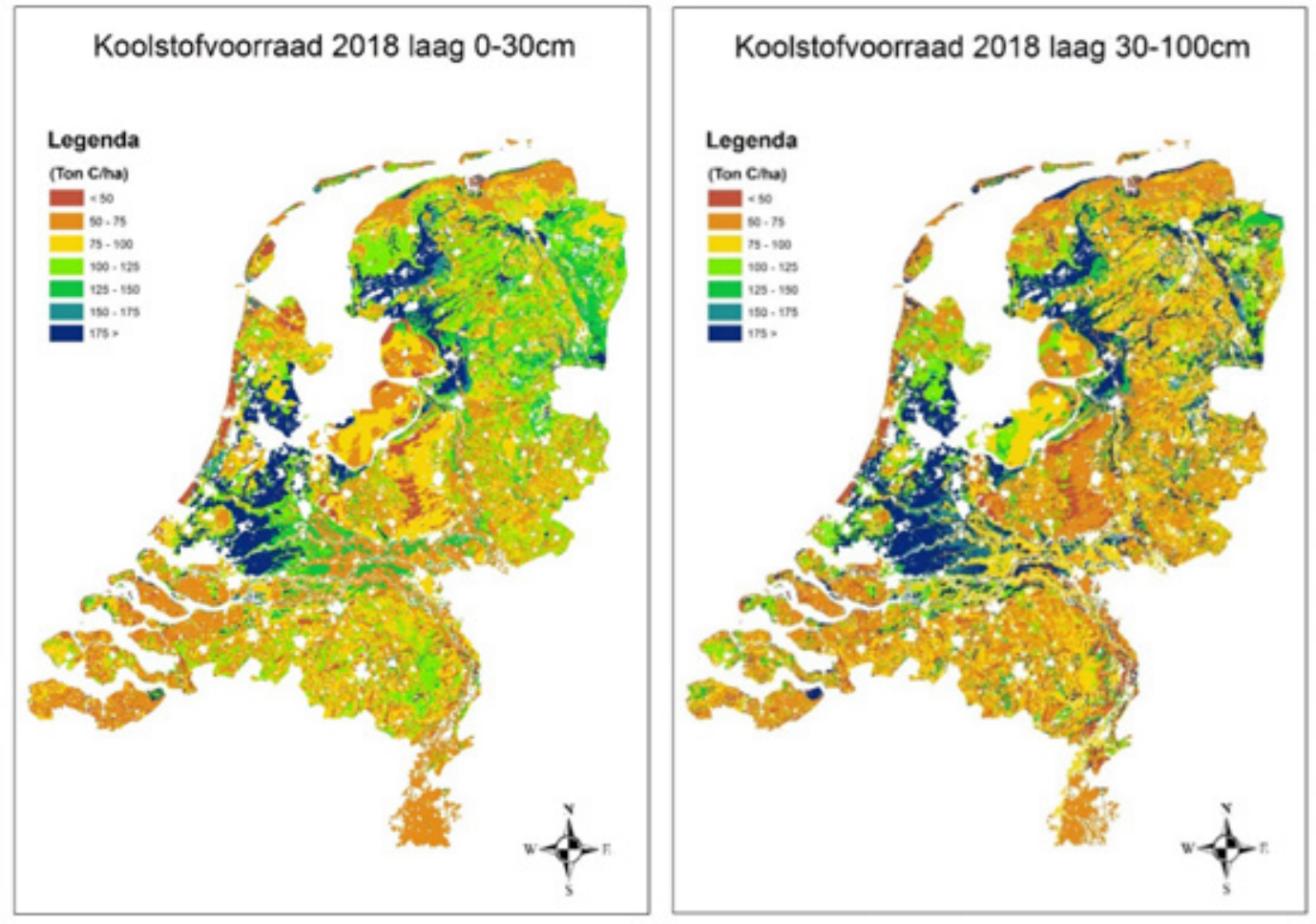

Figuur 23 Koolstofvoorraden in de Nederlandse bodem in 2018 voor de lagen 0-30 cm (links) en voor de laag 30-100 cm (rechts), berekend op basis van de Landelijke Steekproef Kaarteenheden. 


\subsection{Veranderingen in de koolstofvoorraad}

In deze paragraaf wordt een schatting gegeven van verandering in voorraad organische stof, gehalte aan organische stof en dichtheid voor de laag van 0 tot $30 \mathrm{~cm}$ en de laag van 30 tot $100 \mathrm{~cm}$. Zoals in Tabel 4 is beschreven, wijkt de methodiek die in 2018 is gehanteerd af van de methodiek zoals deze in tijden van de LSK is uitgevoerd. Voor 2018 is de schatting gebaseerd op de metingen aan dichtheid die in dat jaar zijn uitgevoerd. Voor 1998 is gebruikgemaakt van dichtheden die destijds zijn afgeleid met behulp van pedotransferfuncties.

\subsubsection{Alle gronden in Nederland}

Figuur 24 geeft alle deelgebieden weer die in 2018 zijn bemonsterd. Ook is weergegeven voor welke deelgebieden onvoldoende meetgegevens beschikbaar waren om de verandering in de voorraad organische stof, gehalte aan organische stof en dichtheid te bepalen inclusief een standaardfout, gebieden dus met geen of slechts één bemonsterde locatie.

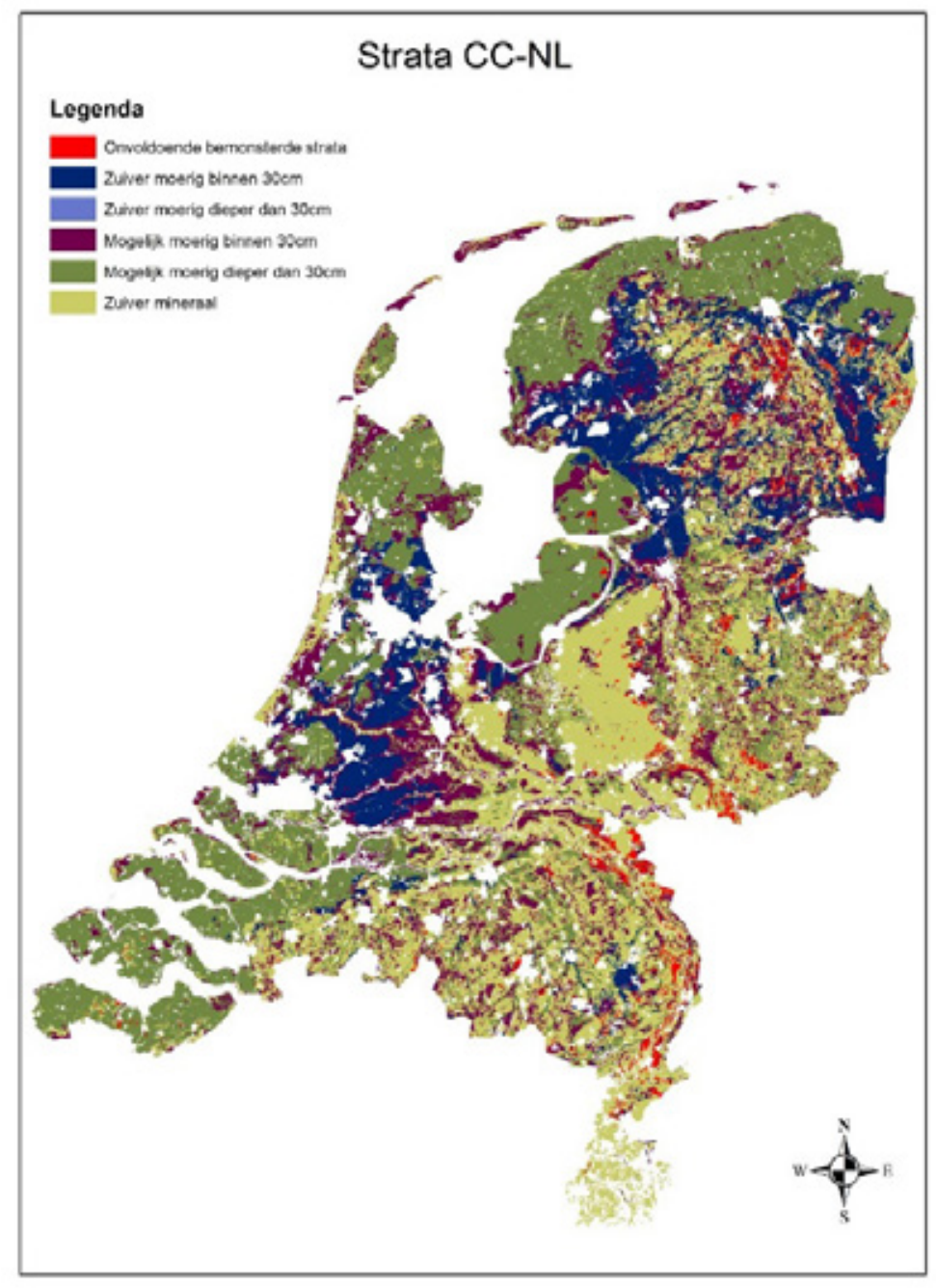

Figuur 24 Alle deelgebieden die wel of niet bemonsterd zijn in 2018.

Op basis van de beschikbare data is een gemiddeld gehalte aan organische stof voor Nederland (2.870.671 ha) geschat en zijn met behulp van de gemeten dichtheden de actuele koolstofvoorraad in de bodem van Nederland berekend (Tabel 7 en Tabel 8). 
Tabel $7 \quad$ Schatting voor heel Nederland van (verandering in) voorraad organische stof, gehalte aan organische stof en dichtheid van de laag 0-30 cm in de periode 1998-2018. Bij deze voorlopige schatting is 37.512 ha buiten beschouwing gelaten, omdat voor dit gebied te weinig data waren in de steekproef van 2018. Standaardfouten tussen haakjes, vetgedrukte waarden zijn significant bij een significantieniveau van 0,05.

\begin{tabular}{|c|c|c|c|c|}
\hline grootheid & 1998 & 2018 & $\begin{array}{l}\text { verandering } \\
2018-1998\end{array}$ & $\begin{array}{l}95 \%- \\
\text { betrouwbaar- } \\
\text { heidsinterval } \\
\text { verandering }\end{array}$ \\
\hline $\begin{array}{l}\text { voorraad organische } \\
\text { stof (ton/ha) }\end{array}$ & $198,47(2,55)$ & $185,82(2,44)$ & $-12,7(2,7)$ & {$[-18,0 ;-7,3]$} \\
\hline $\begin{array}{l}\text { voorraad organische } \\
\text { stof (Mton) }\end{array}$ & $569,75(7,31)$ & $533,41(7,00)$ & $-36,33(7,85)$ & {$[-51,72 ;-20,94]$} \\
\hline $\begin{array}{l}\text { gemiddeld gehalte aan } \\
\text { organische stof }(\%)\end{array}$ & $6,85(0,18)$ & $6,43(0,14)$ & $-0,42(0,15)$ & {$[-0,71 ;-0,13]$} \\
\hline $\begin{array}{l}\text { gemiddelde dichtheid } \\
\left(\mathrm{g} / \mathrm{cm}^{3}\right)\end{array}$ & $1,28(0,01)$ & $1,19(0,01)$ & $-0,08(0,01)$ & {$[-0,10 ;-0,06]$} \\
\hline
\end{tabular}

Tabel 8 Schatting voor heel Nederland van (verandering in) voorraad organische stof, gehalte aan organische stof en dichtheid van de laag $30-100 \mathrm{~cm}$ in de periode 1998-2018. Bij deze voorlopige schatting is 37.512 ha buiten beschouwing gelaten, omdat voor dit gebied te weinig data waren in de steekproef van 2018. Standaardfouten tussen haakjes, vetgedrukte waarden zijn significant bij een significantieniveau van 0,05.

\begin{tabular}{|c|c|c|c|c|}
\hline grootheid & 1998 & 2018 & $\begin{array}{l}\text { verandering } \\
2018-1998\end{array}$ & $\begin{array}{l}95 \%- \\
\text { betrouwbaar- } \\
\text { heidsinterval } \\
\text { verandering }\end{array}$ \\
\hline $\begin{array}{l}\text { voorraad organische } \\
\text { stof (ton/ha) }\end{array}$ & $294,18(5,04)$ & $240,94(4,40)$ & $-53,24(5,02)$ & {$[-63,09 ;-43,39]$} \\
\hline $\begin{array}{l}\text { voorraad organische } \\
\text { stof (Mton) }\end{array}$ & $844,49(14,46)$ & $691,66(12,62)$ & $-152,83(14,42)$ & {$[-181,10 ;-124,56]$} \\
\hline $\begin{array}{l}\text { gemiddeld gehalte aan } \\
\text { organische stof }(\%)\end{array}$ & $7,82(0,26)$ & $5,11(0,16)$ & $-2,71(0,23)$ & {$[-3,15 ;-2,27]$} \\
\hline $\begin{array}{l}\text { gemiddelde dichtheid } \\
\left(\mathrm{g} / \mathrm{cm}^{3}\right)\end{array}$ & $1,33(0,01)$ & $1,24(0,01)$ & $-0,09(0,01)$ & {$[-0,11 ;-0,07]$} \\
\hline
\end{tabular}

Uit de resultaten in Tabel 7 en Tabel 8 kan worden opgemaakt:

- Voor het totale gebied van 2.870.671 hectare is het gemiddelde gehalte aan organische stof in de laag van 0 tot $30 \mathrm{~cm}$ tussen 2000 en 2018 significant afgenomen van 6,85 naar 6,43\% (bij een significantieniveau van 0,05$)$.

- Voor het totale gebied van 2.870.671 hectare is het gemiddelde organische stofgehalte in de laag van 30 tot $100 \mathrm{~cm}$ tussen 2000 en 2018 significant afgenomen van 7,82 naar 5,11\% (bij een significantieniveau van 0,05).

\subsubsection{Minerale gronden}

Er is onderscheid gemaakt naar deelgebieden die volgens de Bodemkaart van Nederland, schaal 1 : 50.000 zoals gebruikt bij de LSK (Figuur 15), uitsluitend uit minerale gronden bestaan en uit gronden met veen en moerig materiaal. Bij deze laatste groep is verder onderscheid gemaakt naar de diepte waarbinnen veen en moerig materiaal voorkomt, en naar deelgebieden met uitsluitend veen- en moerige gronden of deelgebieden met plaatselijk veen- en moerige gronden (Bijlage 2). Figuur 25 geeft de deelgebieden weer die volgens de Bodemkaart van Nederland, schaal $1: 50.000$, uitsluitend uit minerale gronden bestaan. 


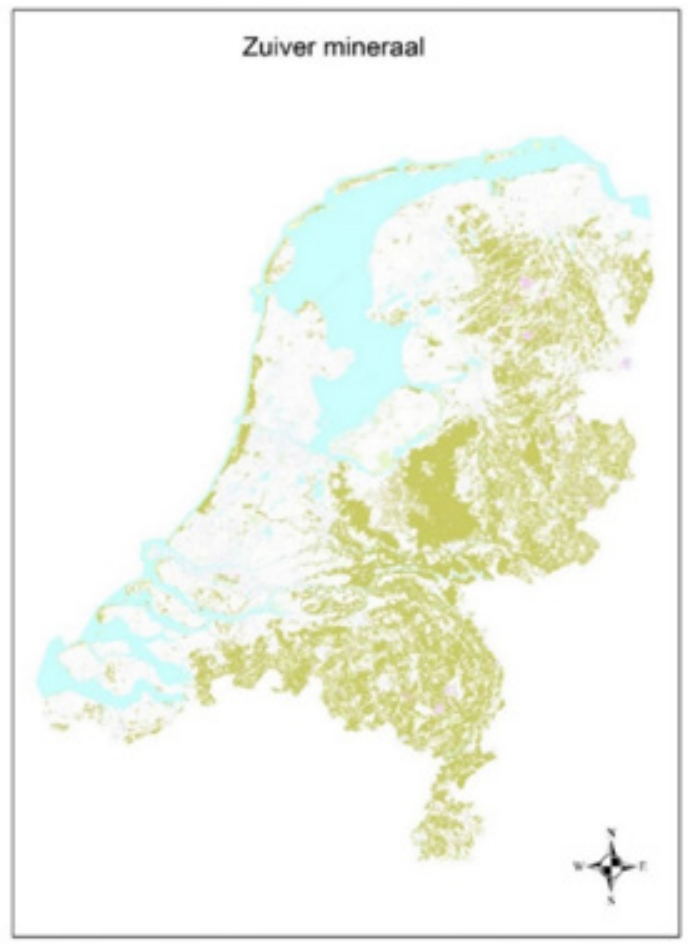

Figuur 25 Deelgebieden (strata) van de LSK die volgens de Bodemkaart van Nederland, schaal 1 : 50.000, uitsluitend uit minerale gronden bestaan.

De schattingen zoals weergegeven in Tabel 9 en Tabel 10 hebben betrekking op de deelgebieden van de LSK die volgens de Bodemkaart van Nederland, schaal $1: 50.000$, alleen uit minerale gronden (zand, zavel en klei) bestaan (1.039.521 ha).

Tabel 9 Schatting van (verandering in) voorraad organische stof, gehalte aan organische stof en dichtheid van de laag $0-30 \mathrm{~cm}$ in de periode 1998-2018, in deelgebieden met volgens de bodemkaart uitsluitend minerale gronden (Bijlage 2). Standaardfouten tussen haakjes, vetgedrukte waarden zijn significant bij een significantieniveau van 0,05.

\begin{tabular}{|c|c|c|c|c|}
\hline grootheid & 1998 & 2018 & $\begin{array}{l}\text { verandering } \\
\text { 2018-1998 }\end{array}$ & $\begin{array}{l}95 \%- \\
\text { betrouwbaar- } \\
\text { heidsinterval } \\
\text { verandering }\end{array}$ \\
\hline $\begin{array}{l}\text { voorraad organische } \\
\text { stof (ton/ha) }\end{array}$ & $161,10(3,82)$ & $148,57(3,53)$ & $-12,53(4,02)$ & {$[-20,40 ;-4,65]$} \\
\hline $\begin{array}{l}\text { Voorraad organische } \\
\text { stof (Mton) }\end{array}$ & $167,46(3,97)$ & $154,44(3,76)$ & $-13,02(4,18)$ & {$[-21,21 ;-4,84]$} \\
\hline $\begin{array}{l}\text { gemiddeld gehalte aan } \\
\text { organische stof (\%) }\end{array}$ & $4,01(0,11)$ & $4,11(0,13)$ & $0,10(0,13)$ & {$[-0,14 ; 0,35]$} \\
\hline $\begin{array}{l}\text { gemiddelde dichtheid } \\
\left(\mathrm{g} / \mathrm{cm}^{3}\right)\end{array}$ & $1,39(0,01)$ & $1,27(0,02)$ & $-0,13(0,02)$ & {$[-0,16 ;-0,09]$} \\
\hline
\end{tabular}


Tabel 10 Schatting van (verandering in) voorraad organische stof, gehalte aan organische stof en dichtheid van de laag 30-100 cm in de periode 1998-2018, in deelgebieden met volgens de bodemkaart uitsluitend minerale gronden (Bijlage 2). Standaardfouten tussen haakjes, vetgedrukte waarden zijn significant bij een significantieniveau van 0,05.

\begin{tabular}{|c|c|c|c|c|}
\hline grootheid & 1998 & 2018 & $\begin{array}{l}\text { verandering } \\
2018-1998\end{array}$ & $\begin{array}{l}95 \%- \\
\text { betrouwbaar- } \\
\text { heidsinterval } \\
\text { verandering }\end{array}$ \\
\hline $\begin{array}{l}\text { voorraad organische } \\
\text { stof (ton/ha) }\end{array}$ & $181,63(6,65)$ & $162,45(5,94)$ & $-19,19(7,06)$ & {$[-33,02 ;-5,35]$} \\
\hline $\begin{array}{l}\text { voorraad organische } \\
\text { stof (Mton) }\end{array}$ & $188,81(6,92)$ & $168,87(6,17)$ & $-19,95(7,34)$ & {$[-34,32 ;-5,57]$} \\
\hline $\begin{array}{l}\text { gemiddeld gehalte aan } \\
\text { organische stof (\%) }\end{array}$ & $1,90(0,09)$ & $1,78(0,08)$ & $-0,11(0,09)$ & {$[-0,29 ; 0,07]$} \\
\hline $\begin{array}{l}\text { gemiddelde dichtheid } \\
\left(\mathrm{g} / \mathrm{cm}^{3}\right)\end{array}$ & $1,50(0,01)$ & $1,42(0,02)$ & $-0,08(0,02)$ & {$[-0,12 ;-0,03]$} \\
\hline
\end{tabular}

Uit Tabel 9 en Tabel 10 kan worden opgemaakt dat voor het deel van het gebied met uitsluitend minerale gronden (1.039.521 ha) er geen verandering van het gehalte aan organische stof aangetoond kan worden. Dit geldt zowel voor de laag van 0 tot $30 \mathrm{~cm}$ als voor de laag van 30 tot $100 \mathrm{~cm}$. De veranderingen in dichtheden en voorraden zijn wel significant, bij een significantieniveau van 0,05.

\subsubsection{Veen- en moerige gronden}

Figuur 26 geeft de ligging van de deelgebieden (strata) van de LSK weer die volgens de Bodemkaart van Nederland, schaal $1: 50.000$, uitsluitend uit gronden bestaan met veen in de laag van 0 tot $30 \mathrm{~cm}$.

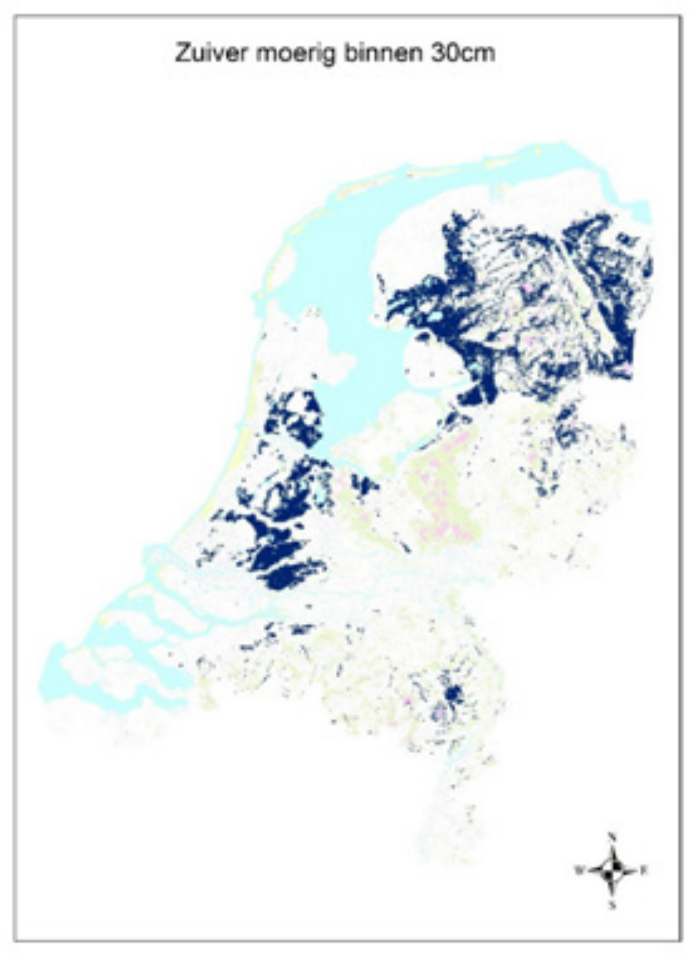

Figuur 26 Deelgebieden (strata) van de LSK die volgens de Bodemkaart van Nederland, schaal $1: 50.000$, uitsluitend uit gronden bestaan met veen in de laag van 0 tot $30 \mathrm{~cm}$.

De schattingen zoals weergegeven in Tabel 11 en Tabel 12 hebben betrekking op deelgebieden van de LSK die volgens de Bodemkaart van Nederland, schaal $1: 50.000$, alleen uit gronden bestaan waarin veen voorkomt tussen 0 en $30 \mathrm{~cm}$ (393.685 ha). 
Tabel 11 Schatting van (verandering in) voorraad organische stof, gehalte aan organische stof en dichtheid van de laag 0-30 cm in de periode 1998-2018, in deelgebieden die volgens de bodemkaart uit veen- en moerige gronden bestaan met moerig materiaal tussen 0 en $30 \mathrm{~cm}$ (Bijlage 2).

Standaardfouten tussen haakjes, vetgedrukte waarden zijn significant (bij een significantieniveau van 0,05).

\begin{tabular}{|c|c|c|c|c|}
\hline grootheid & 1998 & 2018 & $\begin{array}{l}\text { verandering } \\
2018-1998\end{array}$ & $\begin{array}{l}95 \%- \\
\text { betrouwbaar- } \\
\text { heidsinterval } \\
\text { verandering }\end{array}$ \\
\hline $\begin{array}{l}\text { voorraad organische } \\
\text { stof (ton/ha) }\end{array}$ & $315,88(11.44)$ & $325,68(8,56)$ & $9,80(11,58)$ & {$[-12,90 ; 32,50]$} \\
\hline $\begin{array}{l}\text { gemiddeld gehalte aan } \\
\text { organische stof (\%) }\end{array}$ & $17,65(1,13)$ & $16,09(0,79)$ & $-1,56(0,93)$ & {$[-3,38 ; 0,26]$} \\
\hline $\begin{array}{l}\text { gemiddelde dichtheid } \\
\left(\mathrm{g} / \mathrm{cm}^{3}\right)\end{array}$ & $0,95(0,03)$ & $0,88(0,02)$ & $-0,07(0,02)$ & {$[-0,12 ;-0,02]$} \\
\hline
\end{tabular}

Tabel 12 Schatting van (verandering in) voorraad organische stof, gehalte aan organische stof en dichtheid van de laag 30-100 cm in de periode 1998-2018, in deelgebieden die volgens de bodemkaart uit veen- en moerige gronden bestaan met moerig materiaal tussen 0 en $30 \mathrm{~cm}$ (Bijlage 2).

Standaardfouten tussen haakjes, vetgedrukte waarden zijn significant (bij een significantieniveau van 0,05).

\begin{tabular}{|c|c|c|c|c|}
\hline grootheid & 1998 & 2018 & $\begin{array}{l}\text { verandering } \\
2018-1998\end{array}$ & $\begin{array}{l}95 \%- \\
\text { betrouwbaar- } \\
\text { heidsinterval } \\
\text { verandering }\end{array}$ \\
\hline $\begin{array}{l}\text { voorraad organische } \\
\text { stof (ton/ha) }\end{array}$ & $612,24(20,09)$ & $529,75(15.43)$ & $-82,48(21,35)$ & {$[-124,33 ;-40,64]$} \\
\hline $\begin{array}{l}\text { gemiddeld gehalte aan } \\
\text { organische stof }(\%)\end{array}$ & $31,14(1,42)$ & $19,50(0,97)$ & $-11,64(1,34)$ & {$[-14,27 ;-9,00]$} \\
\hline $\begin{array}{l}\text { gemiddelde dichtheid } \\
\left(\mathrm{g} / \mathrm{cm}^{3}\right)\end{array}$ & $0,85(0.03)$ & $0,83(0.03)$ & $-0,01(0,03)$ & {$[-0,07 ; 0,04]$} \\
\hline
\end{tabular}

Uit Tabel 11 en Tabel 12 kan worden opgemaakt dat voor het deel van het gebied met uitsluitend gronden waarin veen en moerig materiaal binnen $30 \mathrm{~cm}$ voorkomt (393.685 ha), er geen verandering van het gehalte aan organische stof in de laag van 0 tot $30 \mathrm{~cm}$ aangetoond kan worden, bij een significantieniveau van 0,05 . Voor het deel van het gebied met uitsluitend gronden waarin veen en moerig materiaal binnen $30 \mathrm{~cm}$ voorkomt (393.685 ha) is het gehalte aan organische stof in de laag van 30 tot $100 \mathrm{~cm}$ tussen 1998 en 2018 significant afgenomen van 31,14 naar 19,50\% (bij een significantieniveau van 0,05$)$.

Tabel 13 en Tabel 14 hebben betrekking op deelgebieden van de LSK die volgens de Bodemkaart van Nederland, schaal $1: 50.000$, alleen uit gronden bestaan waarin veen voorkomt tussen 30 en $100 \mathrm{~cm}$ (1247 ha). 
Tabel 13 Schatting van (verandering in) voorraad organische stof, gehalte aan organische stof en dichtheid van de laag 0-30 cm in de periode 1998-2018, in deelgebieden waarin volgens de bodemkaart veen- en moerige gronden voorkomen met moerig materiaal tussen 30 en $100 \mathrm{~cm}$ (Bijlage 2). Dit betreft uitsluitend deelgebied 2007 (1247 hectare). Standaardfouten tussen haakjes.

\begin{tabular}{|c|c|c|c|c|}
\hline grootheid & 1998 & 2018 & $\begin{array}{l}\text { verandering } \\
2018-1998\end{array}$ & $\begin{array}{l}95 \%- \\
\text { betrouwbaar- } \\
\text { heidsinterval } \\
\text { verandering }\end{array}$ \\
\hline $\begin{array}{l}\text { voorraad organische } \\
\text { stof (ton/ha) }\end{array}$ & $253,41(24,29)$ & $259,41(40,62)$ & $6,00(16,33)$ & {$[-26,01 ; 38,00]$} \\
\hline $\begin{array}{l}\text { gemiddeld gehalte aan } \\
\text { organische stof }(\%)\end{array}$ & $7,5(1)$ & $10,19(3,54)$ & $2,69(2,53)$ & {$[-2,28 ; 7,67]$} \\
\hline $\begin{array}{l}\text { gemiddelde dichtheid } \\
\left(\mathrm{g} / \mathrm{cm}^{3}\right)\end{array}$ & $1,13(0,04)$ & $0,91(0,18)$ & $-0,22(0,14)$ & {$[-0,50 ; 0,06]$} \\
\hline
\end{tabular}

Tabel 14 Schatting van (verandering in) voorraad organische stof, gehalte aan organische stof en dichtheid van de laag 30-100 cm in de periode 1998-2018, in deelgebieden waarin volgens de bodemkaart veen- en moerige gronden voorkomen met moerig materiaal tussen 30 en $100 \mathrm{~cm}$. Dit betreft uitsluitend deelgebied 2007 (1247 hectare). Standaardfouten tussen haakjes, vetgedrukte waarden zijn significant bij een significantieniveau van 0,05.

\begin{tabular}{|c|c|c|c|c|}
\hline grootheid & 1998 & 2018 & $\begin{array}{l}\text { verandering } \\
\text { 2018-1998 }\end{array}$ & $\begin{array}{l}95 \%- \\
\text { betrouwbaar- } \\
\text { heidsinterval } \\
\text { verandering }\end{array}$ \\
\hline $\begin{array}{l}\text { voorraad organische } \\
\text { stof (ton/ha) }\end{array}$ & $1000,3(97,7)$ & $492,03(363,69)$ & $-508,30(266,02)$ & {$[-1029,70 ; 13,09]$} \\
\hline $\begin{array}{l}\text { gemiddeld gehalte aan } \\
\text { organische stof }(\%)\end{array}$ & $48(15,7)$ & $14,76(13,01)$ & $-33,24(2,68)$ & {$[-38,50 ;-27,98]$} \\
\hline $\begin{array}{l}\text { gemiddelde dichtheid } \\
\left(\mathrm{g} / \mathrm{cm}^{3}\right)\end{array}$ & $0,45(0,14)$ & $0,75(0.31)$ & $0,29(0,16)$ & {$[-0,02 ; 0,61]$} \\
\hline
\end{tabular}

Uit Tabel 13 en Tabel 14 kan worden opgemaakt dat voor het deel van het gebied met uitsluitend gronden waarin veen en moerig materiaal tussen 30 en $100 \mathrm{~cm}$ voorkomt (1247 ha), er geen verandering van het organische stofgehalte in de laag van 0 tot $30 \mathrm{~cm}$ aangetoond kan worden. Voor het deel van het gebied met uitsluitend gronden waarin veen en moerig materiaal tussen $30-100 \mathrm{~cm}$ voorkomt (1247 ha), is het organische stofgehalte in de laag van 30 tot $100 \mathrm{~cm}$ tussen 1998 en 2018 significant afgenomen van 48 naar $14,76 \%$ (bij een significantieniveau van 0,05).

Figuur 27 geeft de ligging weer van de deelgebieden van de LSK waarin volgens de Bodemkaart van Nederland, schaal $1: 50.000$, mogelijk moerig materiaal voorkomt in de laag van 0 tot $30 \mathrm{~cm}$ (393.685 ha). 


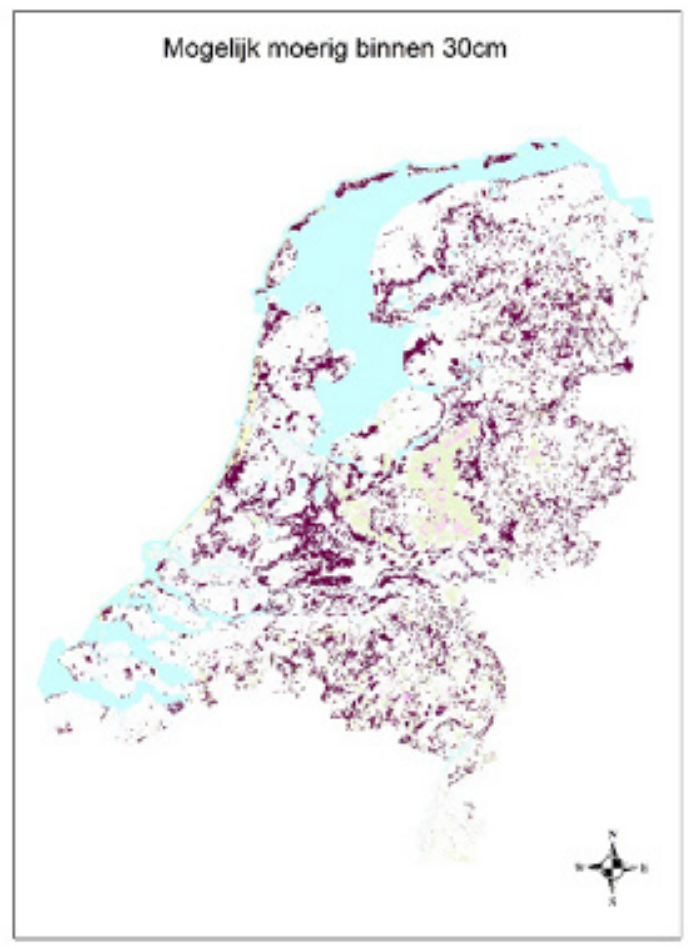

Figuur 27 Deelgebieden van de LSK waarin volgens de Bodemkaart van Nederland, schaal 1 : 50.000, mogelijk moerig materiaal voorkomt in de laag van $0-30 \mathrm{~cm}$.

Tabel 15 en Tabel 16 hebben betrekking op deelgebieden van de LSK die volgens de Bodemkaart van Nederland, schaal $1: 50.000$, onder andere uit gronden bestaan waarin veen voorkomt tussen 0 en $30 \mathrm{~cm}$ (393.685 ha).

Tabel 15 Schatting van (verandering in) voorraad organische stof, gehalte aan organische stof en dichtheid van de laag 0-30 cm in de periode 1998-2018, in deelgebieden waarin volgens de bodemkaart onder andere veen- en moerige gronden voorkomen met moerig materiaal tussen 0 en $30 \mathrm{~cm}$. Standaardfouten tussen haakjes, vetgedrukte waarden zijn significant bij een significantieniveau van 0,05 .

\begin{tabular}{|c|c|c|c|c|}
\hline grootheid & 1998 & 2018 & $\begin{array}{l}\text { verandering } \\
2018-1998\end{array}$ & $\begin{array}{l}95 \%- \\
\text { betrouwbaar- } \\
\text { heidsinterval } \\
\text { verandering }\end{array}$ \\
\hline $\begin{array}{l}\text { voorraad organische } \\
\text { stof (ton/ha) }\end{array}$ & $216,26(6.08)$ & $216,53(7,90)$ & $0,27(7,55)$ & {$[-14,52 ; 15,06]$} \\
\hline $\begin{array}{l}\text { gemiddeld gehalte aan } \\
\text { organische stof (\%) }\end{array}$ & $7,78(0,40)$ & $7,91(0,39)$ & $0,13(0,30)$ & {$[-0.45 ; 0,72]$} \\
\hline $\begin{array}{l}\text { gemiddelde dichtheid } \\
\left(\mathrm{g} / \mathrm{cm}^{3}\right)\end{array}$ & $1,24(0,01)$ & $1,10(0,02)$ & $-0,14(0,02)$ & {$[-0,18 ;-0,10]$} \\
\hline
\end{tabular}


Tabel 16 Schatting van (verandering in) voorraad organische stof, gehalte aan organische stof en dichtheid van de laag 30-100 cm in de periode 1998-2018, in deelgebieden waarin volgens de bodemkaart onder andere veen- en moerige gronden voorkomen met moerig materiaal tussen 0 en $30 \mathrm{~cm}$. Standaardfouten tussen haakjes, vetgedrukte waarden zijn significant bij een significantieniveau van 0,05 .

\begin{tabular}{|c|c|c|c|c|}
\hline grootheid & 1998 & 2018 & $\begin{array}{l}\text { verandering } \\
2018-1998\end{array}$ & $\begin{array}{l}95 \%- \\
\text { betrouwbaar- } \\
\text { heidsinterval } \\
\text { verandering }\end{array}$ \\
\hline $\begin{array}{l}\text { voorraad organische } \\
\text { stof (ton/ha) }\end{array}$ & $301,30(12,76)$ & $286,92(14,50)$ & $-14,38(12,15)$ & {$[-38,20 ; 9,43]$} \\
\hline $\begin{array}{l}\text { gemiddeld gehalte aan } \\
\text { organische stof (\%) }\end{array}$ & $8,53(0,72)$ & $5,77(0,48)$ & $-2,76(0,51)$ & {$[-3,76 ;-1,75]$} \\
\hline $\begin{array}{l}\text { gemiddelde dichtheid } \\
\left(\mathrm{g} / \mathrm{cm}^{3}\right)\end{array}$ & $1,29(0,02)$ & $1,14(0,02)$ & $-0,15(0,02)$ & {$[-0,19 ;-0,11]$} \\
\hline
\end{tabular}

Uit Tabel 15 en Tabel 16 blijkt dat voor het deel van het gebied met plaatselijk veen en moerig materiaal binnen $30 \mathrm{~cm}$ (393.685 ha) er geen verandering van het gehalte aan organische stof in de laag van 0 tot $30 \mathrm{~cm}$ aangetoond kan worden bij een significantieniveau van 0,05 . Het gehalte aan organische stof in de laag van 30 tot $100 \mathrm{~cm}$ is tussen 1998 en 2018 significant afgenomen van 8,53 naar $5,77 \%$ (bij een significantieniveau van 0,05 ).

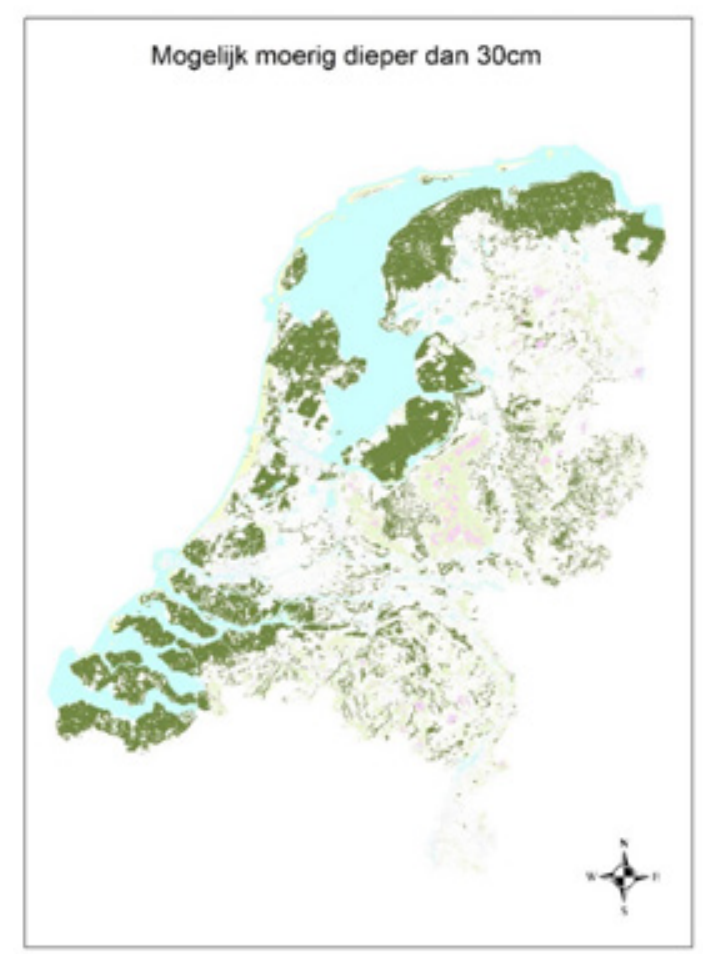

Figuur 28 Deelgebieden met mogelijk moerig materiaal in de laag $30-100 \mathrm{~cm}$.

Tabel 17 en Tabel 18 hebben betrekking op deelgebieden van de LSK die volgens de Bodemkaart van Nederland, schaal $1: 50.000$, onder andere uit gronden bestaan waarin veen voorkomt tussen 30 en $100 \mathrm{~cm}$ (941.203 ha, zie Figuur 28). 
Tabel 17 Schatting van (verandering in) voorraad organische stof, gehalte aan organische stof en dichtheid van de laag 0-30 cm in de periode 1998-2018, in deelgebieden waarin volgens de bodemkaart onder andere veen- en moerige gronden voorkomen met moerig materiaal tussen 30 en $100 \mathrm{~cm}$. Standaardfouten tussen haakjes, vetgedrukte waarden zijn significant bij een significantieniveau van 0,05 .

\begin{tabular}{|c|c|c|c|c|}
\hline grootheid & 1998 & 2018 & $\begin{array}{l}\text { verandering } \\
2018-1998\end{array}$ & $\begin{array}{l}95 \%- \\
\text { betrouwbaar- } \\
\text { heidsinterval } \\
\text { verandering }\end{array}$ \\
\hline $\begin{array}{l}\text { voorraad organische } \\
\text { stof (ton/ha) }\end{array}$ & $181,21(3,07)$ & $152,20(3,17)$ & $-29,01(3,26)$ & {$[-35,41 ;-22,61]$} \\
\hline $\begin{array}{l}\text { gemiddeld gehalte aan } \\
\text { organische stof (\%) }\end{array}$ & $4,99(0,11)$ & $4,17(0,10)$ & $-0,82(0,10)$ & {$[-1,02 ;-0,62]$} \\
\hline $\begin{array}{l}\text { gemiddelde dichtheid } \\
\left(\mathrm{g} / \mathrm{cm}^{3}\right)\end{array}$ & $1.30(0,01)$ & $1,30(0,01)$ & $-0,00(0,01)$ & {$[-0,04 ; 0,02]$} \\
\hline
\end{tabular}

Tabel 18 Schatting van (verandering in) voorraad organische stof, gehalte aan organische stof en dichtheid van de laag 30-100 cm in de periode 1998-2018, in deelgebieden waarin volgens de bodemkaart onder andere veen- en moerige gronden voorkomen met moerig materiaal tussen 30 en $100 \mathrm{~cm}$. Standaardfouten tussen haakjes, vetgedrukte waarden zijn significant bij een significantieniveau van 0,05.

\begin{tabular}{|c|c|c|c|c|}
\hline grootheid & 1998 & 2018 & $\begin{array}{l}\text { verandering } \\
2018-1998\end{array}$ & $\begin{array}{l}95 \%- \\
\text { betrouwbaar- } \\
\text { heidsinterval } \\
\text { verandering }\end{array}$ \\
\hline $\begin{array}{l}\text { voorraad organische } \\
\text { stof (ton/ha) }\end{array}$ & $280,76(8,15)$ & $182,31(6,07)$ & $-98,44(7,31)$ & {$[-112,77 ;-84,12]$} \\
\hline $\begin{array}{l}\text { gemiddeld gehalte aan } \\
\text { organische stof }(\%)\end{array}$ & $4,19(0,33)$ & $2,40(0,14)$ & $-1,78(0,27)$ & {$[-2,31 ;-1,25]$} \\
\hline $\begin{array}{l}\text { gemiddelde dichtheid } \\
\left(\mathrm{g} / \mathrm{cm}^{3}\right)\end{array}$ & $1,37(0,01)$ & $1,26(0,02)$ & $-0,11(0,01)$ & {$[-0,14 ;-0,08]$} \\
\hline
\end{tabular}

Voor het deel van het gebied met plaatselijk veen en moerig materiaal tussen $30-100 \mathrm{~cm}$ ( $941.203 \mathrm{ha}$ ) is een verandering van het gehalte aan organische stof in de laag van 0-30 cm aangetoond bij een significantieniveau van 0,05, namelijk een afname van 4,99 naar 4,17\%.

Voor het deel van het gebied met plaatselijk veen en moerig materiaal tussen $30-100 \mathrm{~cm}$ (941.203 ha) is het organische stofgehalte in de laag van 30-100 cm tussen 1998 en 2018 significant afgenomen van 4,19 naar 2,40\% (bij een significantieniveau van 0,05). 


\subsection{Domeinschattingen voor combinaties van landgebruik en bodemtype}

\subsubsection{Indeling in vier landgebruikscategorieën en zes bodemtypen}

Figuur 29 toont de koolstofvoorraden in de Nederlandse bodem in 1998 in de laag 0-30 cm, Figuur 30 de voorraden in 2018, en Figuur 31 de verandering in voorraden (2018-1998).

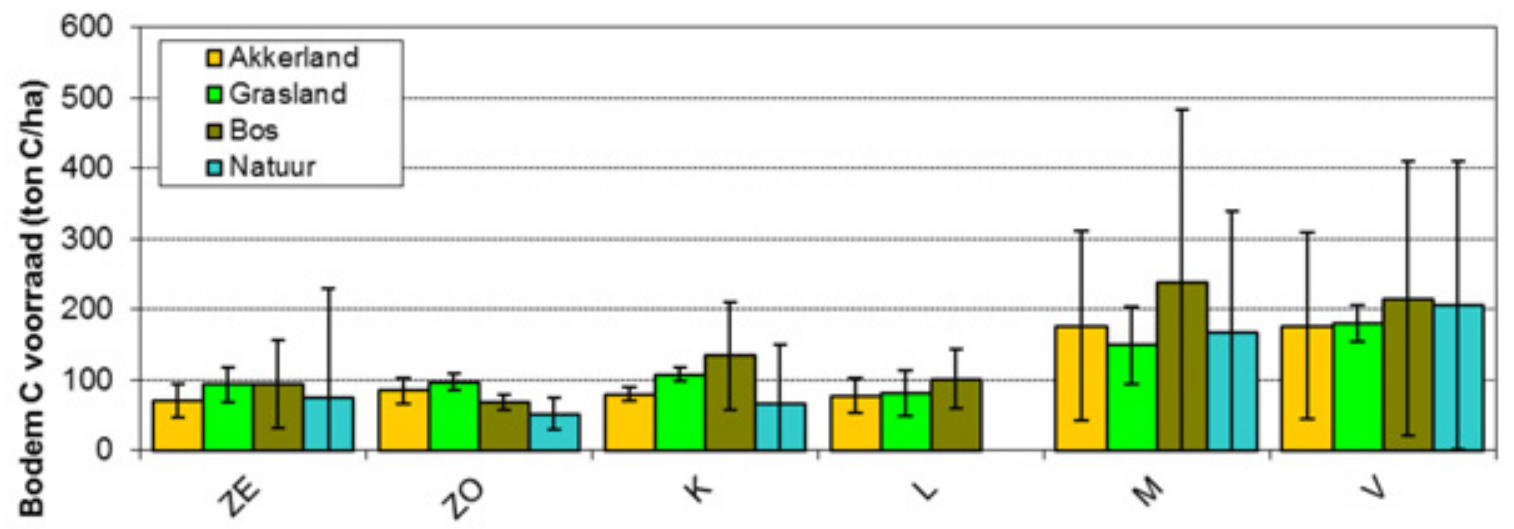

Figuur 29 Koolstofvoorraden in de Nederlandse bodem in 1998 in de laag 0-30 cm, op basis van de Landelijke Steekproef Kaarteenheden. Indeling naar landgebruik in 1998. De error bars geven 95\%betrouwbaarheidsintervallen aan. ZE: zandgronden met een eerdlaag die dikker is dan $30 \mathrm{~cm}$; ZO: overige zandgronden; K: kleigronden; L: leemgronden; M: moerige gronden; V: veengronden.

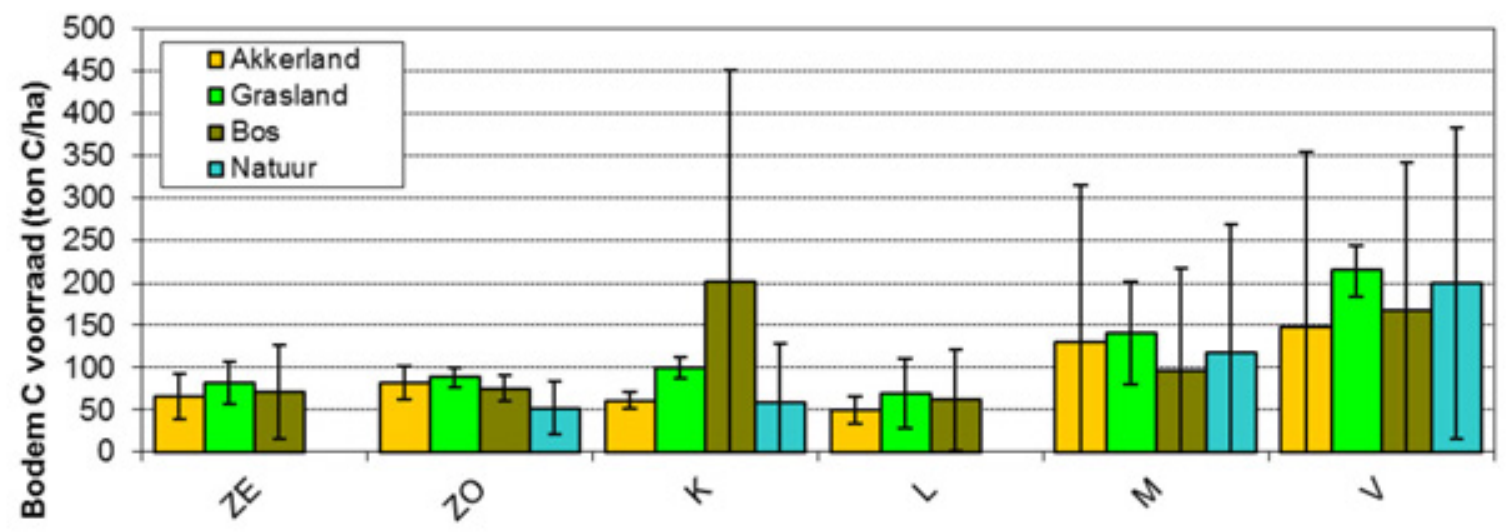

Figuur 30 Koolstofvoorraden in de Nederlandse bodem in 2018 in de laag 0-30 cm, op basis van de Landelijke Steekproef Kaarteenheden. Indeling naar landgebruik in 1998. De error bars geven 95\%betrouwbaarheidsintervallen aan. ZE: zandgronden met een eerdlaag die dikker is dan $30 \mathrm{~cm}$; ZO: overige zandgronden; K: kleigronden; L: leemgronden; M: moerige gronden; V: veengronden. 


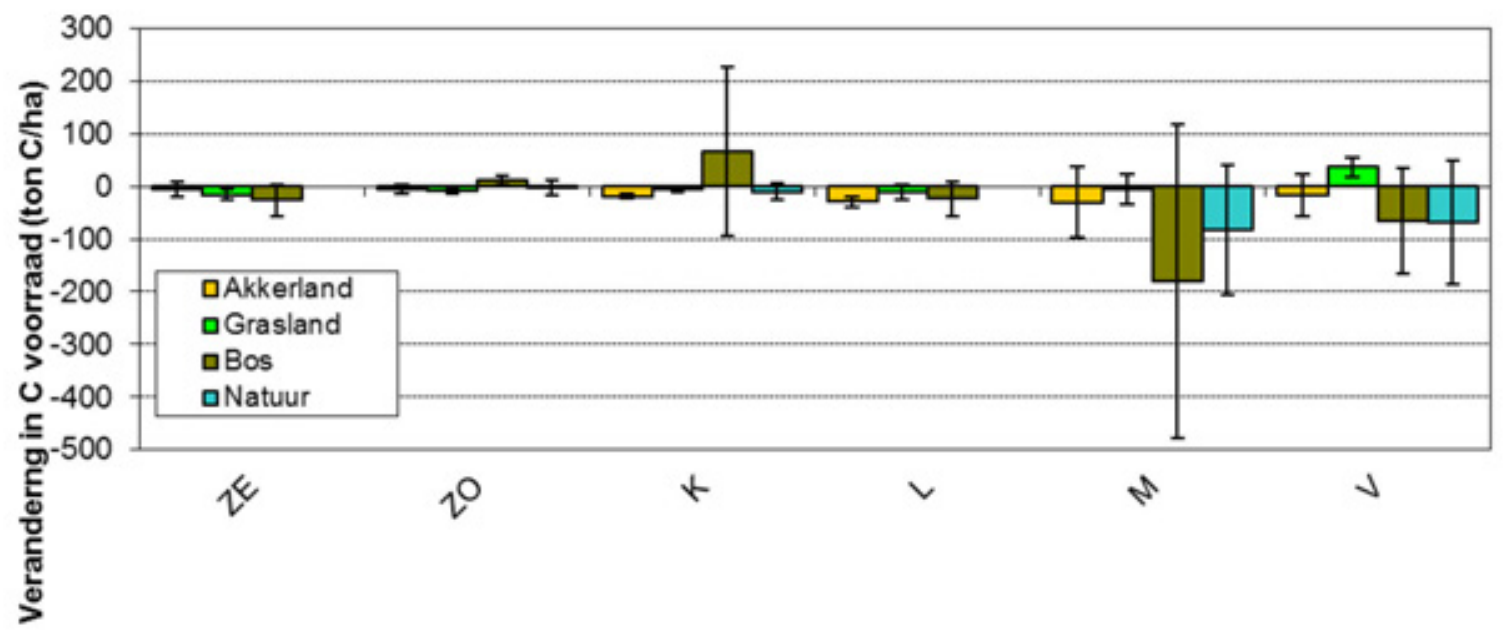

Figuur 31 Verandering in koolstofvoorraad (2018-1998) in de Nederlandse bodem in de laag $0-30 \mathrm{~cm}$, op basis van de Landelijke Steekproef Kaarteenheden. Indeling naar landgebruik in 1998. De error bars geven 95\%-betrouwbaarheidsintervallen aan. ZE: zandgronden met een eerdlaag die dikker is dan $30 \mathrm{~cm}$; ZO: overige zandgronden; K: kleigronden; L: leemgronden; M: moerige gronden; $\checkmark$ : veengronden.

Indien in Figuur 31 de error bars door de nullijn gaan dan zijn verschillen niet aantoonbaar (bij een significantieniveau van 0.05). Als de error bar niet door de nullijn gaat dan is een verschil aangetoond (bij een significantieniveau van 0.05). Uit Figuur 31 komt een wisselend beeld naar voren, waarbij een afname van de koolstofvoorraad onder akkerland gedurende de laatste 20 jaar is aangetoond bij kleien leemgronden. Bij grasland is een geringe afname van de koolstofvoorraad aangetoond bij zandgronden met een eerdlaag dikker dan $30 \mathrm{~cm}$. Bij veengronden is een toename van de koolstofvoorraad aangetoond. Onder bos en overige natuur is een verandering in koolstofvoorraad niet aangetoond.

Figuur 32 toont de koolstofvoorraden in de Nederlandse bodem in 1998 in de laag $30-100 \mathrm{~cm}$, Figuur 33 de voorraden in 2018, en Figuur 34 de verandering in voorraden 2018-1998.

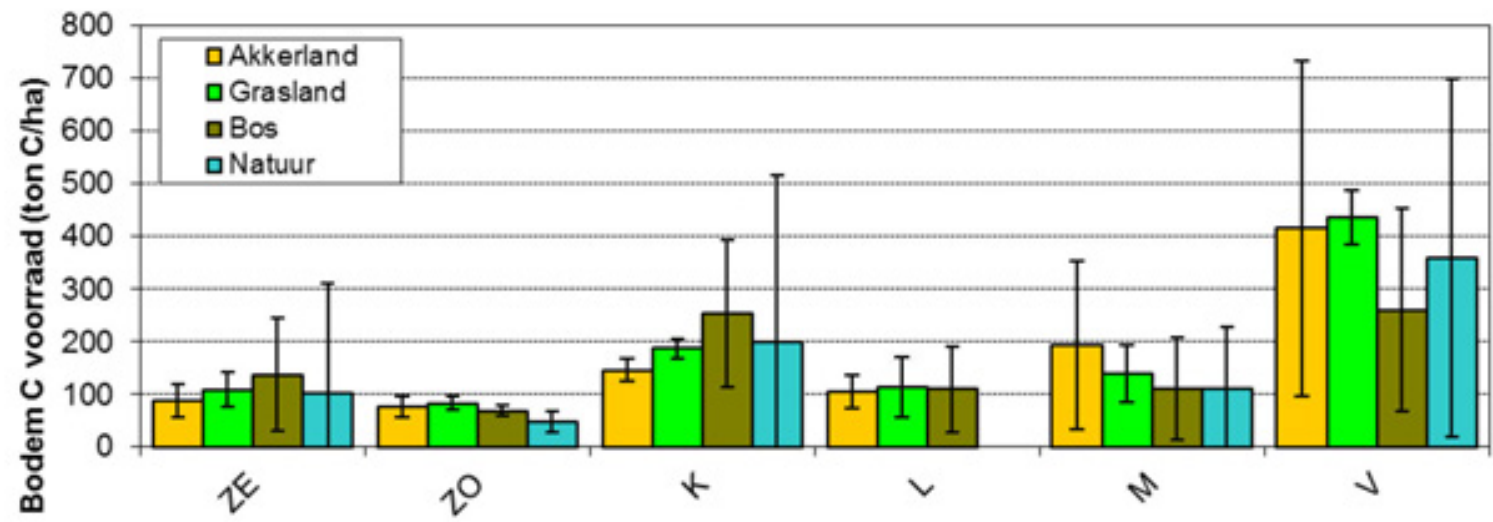

Figuur 32 Koolstofvoorraden in de Nederlandse bodem in 1998 in de laag 30-100 cm, op basis van de Landelijke Steekproef Kaarteenheden. Indeling naar landgebruik in 1998. De error bars geven 95\%betrouwbaarheidsintervallen aan. ZE: zandgronden met een eerdlaag die dikker is dan $30 \mathrm{~cm}$; zO: overige zandgronden; K: kleigronden; L: leemgronden; M: moerige gronden; V: veengronden. 


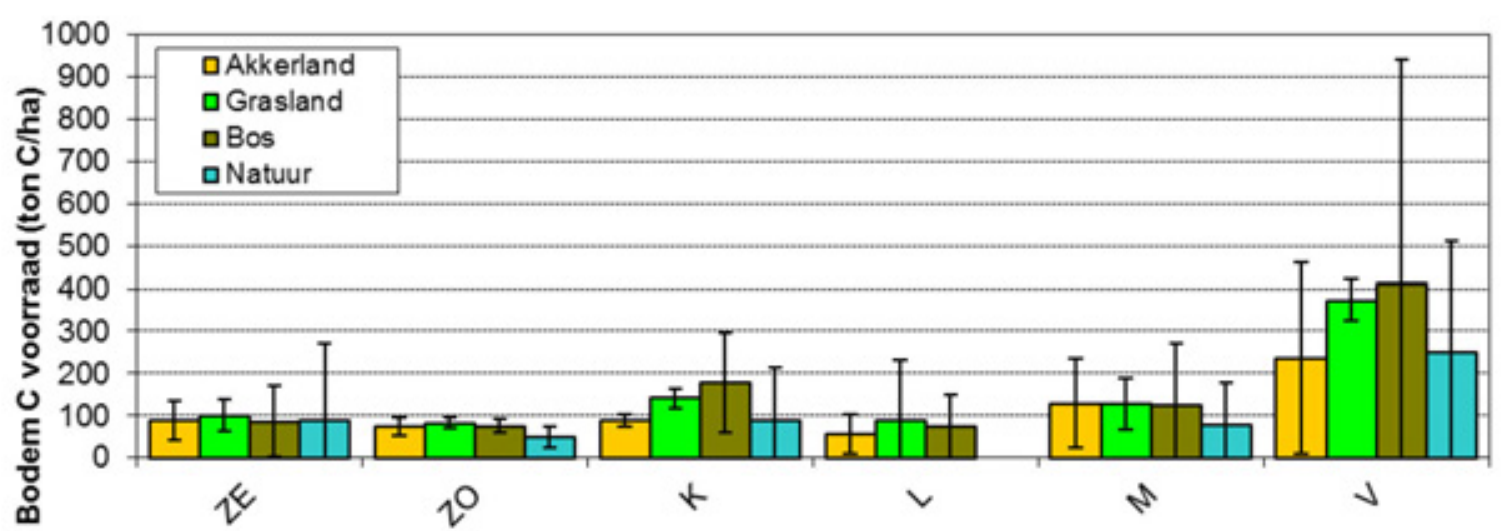

Figuur 33 Koolstofvoorraden in de Nederlandse bodem in 2018 in de laag 30-100 cm, op basis van de Landelijke Steekproef Kaarteenheden. Indeling naar landgebruik in 1998. De error bars geven 95\%betrouwbaarheidsintervallen aan. ZE: zandgronden met een eerdlaag die dikker is dan $30 \mathrm{~cm}$; ZO: overige zandgronden; K: kleigronden; L: leemgronden; M: moerige gronden; V: veengronden.

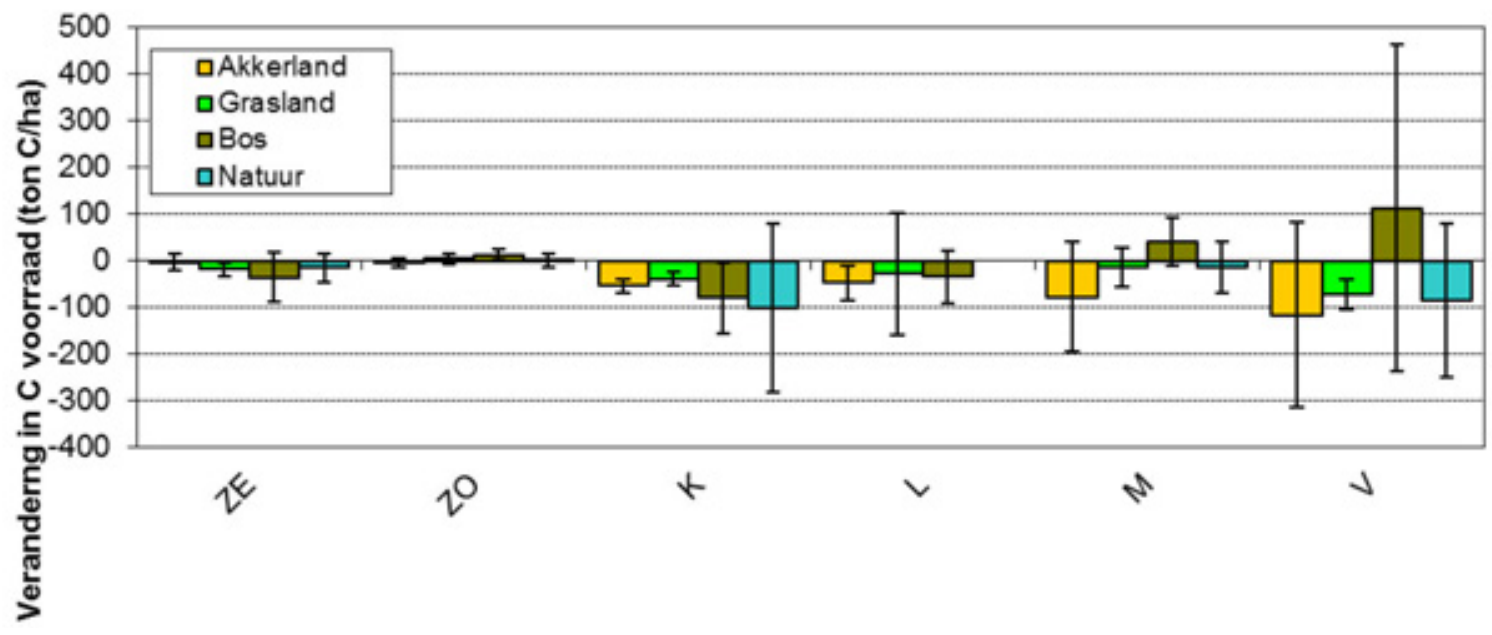

Figuur 34 Verandering in koolstofvoorraad (2018-1998) in de Nederlandse bodem in de laag 30-100 cm, op basis van de Landelijke Steekproef Kaarteenheden. Indeling naar landgebruik in 1998. De error bars geven 95\%-betrouwbaarheidsintervallen aan. ZE: zandgronden met een eerdlaag die dikker is dan $30 \mathrm{~cm}$; ZO: overige zandgronden; K: kleigronden; L: leemgronden; M: moerige gronden; $\mathrm{V}$ : veengronden.

Indien in Figuur 34 de error bars door de nullijn gaan dan zijn verschillen niet aantoonbaar (bij een significantieniveau van 0.05). Als de error bars niet door de nullijn gaan dan zijn veranderingen in de koolstofvoorraad aangetoond (bij een significantieniveau van 0.05). Uit Figuur 34 blijkt dat een afname van de koolstofvoorraad gedurende de laatste 20 jaar kan worden aangetoond bij akkerland op klei en leem en bij grasland op klei en veen. Bij bos op zandgrond zonder eerdlaag is een lichte toename van de koolstofvoorraad aangetoond.

\subsubsection{Indeling in vier landgebruikscategorieën en elf bodemtypen}

Om een vergelijking mogelijk te maken met de indeling voor LULUCF door Lesschen et al. (2012) worden in deze paragraaf de koolstofvoorraden en veranderingen daarin gepresenteerd voor vier landgebruikscategorieën en elf bodemtypen.

Figuur 35 geeft de koolstofvoorraden in 1998 in de laag van 0 tot $30 \mathrm{~cm}$ in de interessegebieden voor LULUCF uit Lesschen et al. (2012), Figuur 36 geeft voorraden in 2018 en Figuur 37 de verschillen (2018-1998). 


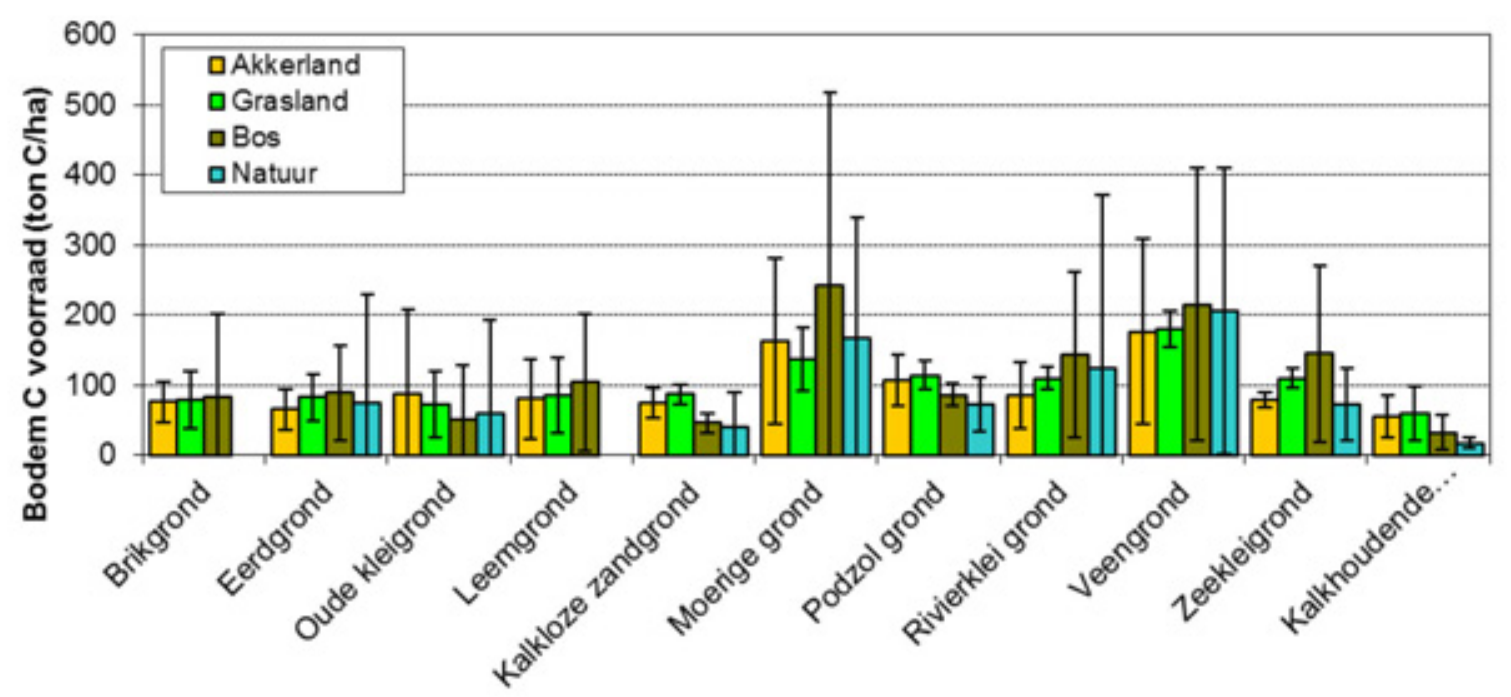

Figuur 35 Koolstofvoorraden in de Nederlandse bodem in 1998 in de laag 0-30 cm, op basis van de Landelijke Steekproef Kaarteenheden. Indeling naar landgebruik in 1998 en LULUCF-rapportage (Lesschen et al., 2012). De error bars geven 95\%-betrouwbaarheidsintervallen aan. (Kalkhoudende ... = kalkhoudende zandgronden.)

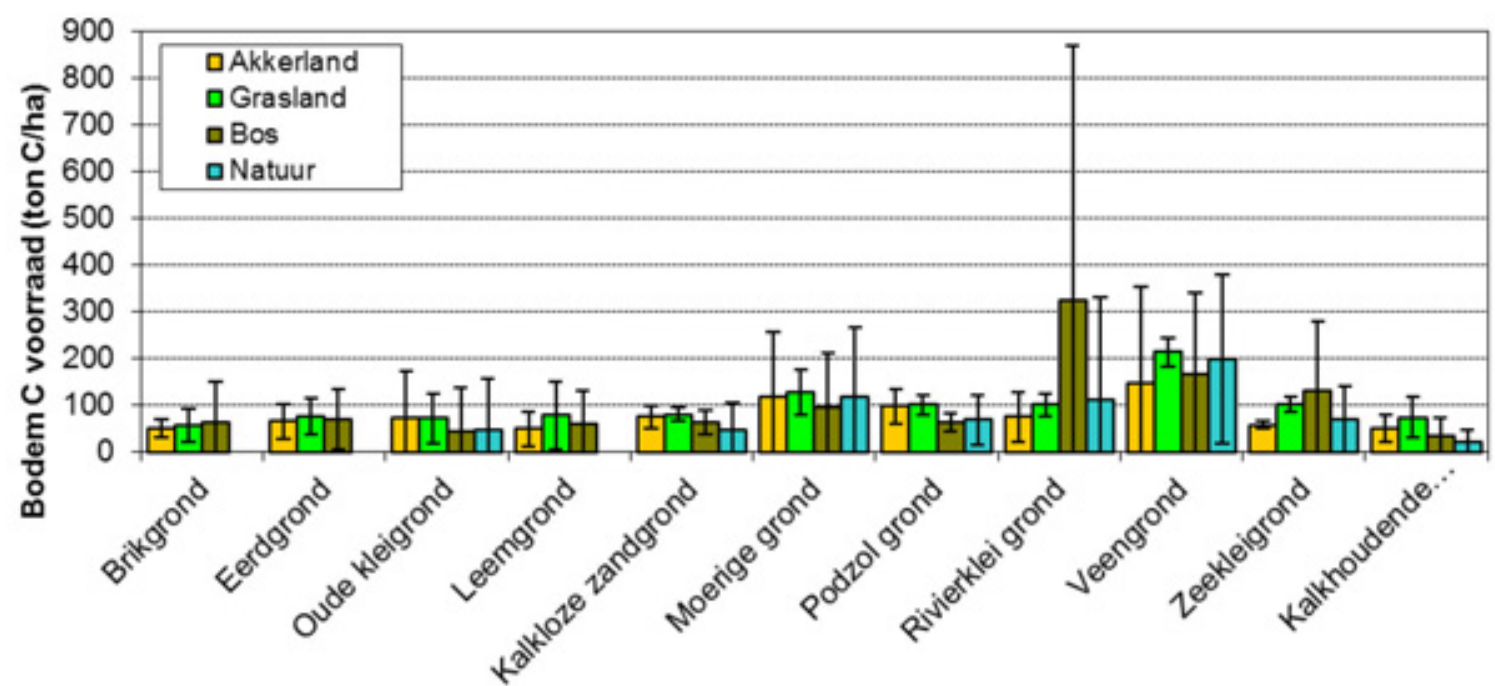

Figuur 36 Koolstofvoorraden in de Nederlandse bodem in 2018 in de laag 0-30 cm, op basis van de Landelijke Steekproef Kaarteenheden. Indeling naar landgebruik in 1998 en LULUCF-rapportage (Lesschen et al., 2012). De error bars geven 95\%-betrouwbaarheidsintervallen aan. (Kalkhoudende ... = kalkhoudende zandgronden.) 


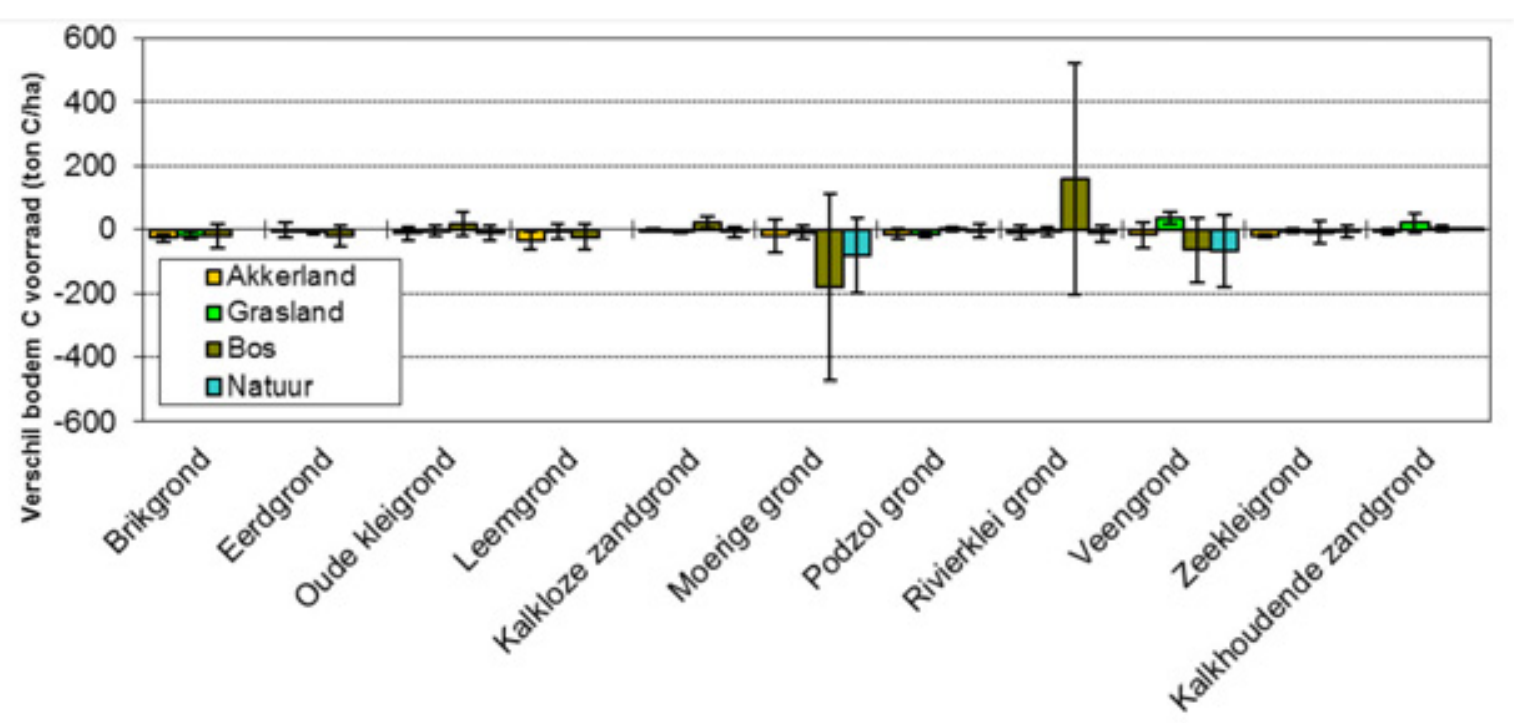

Figuur 37 Verandering in koolstofvoorraad (2018-1998) in de Nederlandse bodem in de laag 0-30 cm, op basis van de Landelijke Steekproef Kaarteenheden. Indeling naar landgebruik in 1998 en LULUCF-rapportage (Lesschen et al., 2012). De error bars geven 95\%-betrouwbaarheidsintervallen aan.

Indien in Figuur 37 de error bars door de nullijn gaan dan zijn de verschillen niet aangetoond bij een significantieniveau van 0.05 . Als de error bars niet door de nullijn gaan dan zijn de verschillen aangetoond bij een significantieniveau van 0.05. Uit Figuur 37 blijkt bij akkerland op brikgrond, leemgrond en zeekleigrond een afname van de koolstofvoorraad gedurende de laatste 20 jaar is aangetoond. In vergelijking met Figuur 34 zijn in Figuur 37 de verschillen minder vaak aantoonbaar. De oorzaak hiervan is dat voor kleinere interessegebieden, met minder steekproefpunten, de nauwkeurigheid van geschatte veranderingen afneemt. 


\subsection{Indringingsweerstand}

Zowel in het onderzoek en het beleid als in de praktijk bestaat de behoefte om meer te weten over de actuele status van bodemverdichting van Nederlandse landbouwgronden. Gezien de landsdekkende meetopzet van de huidige studie, is besloten op deze punten ook de indringingsweerstand te meten. Bodemverdichting wordt gedefinieerd als verdichting en vervorming van de bodemstructuur, gewoonlijk als gevolg van mechanische spanningen. Verdichting veroorzaakt een afname van de totale en luchtgevulde porositeit en van de indringingsweerstand van de bodem. Verdichting verlaagt tevens de productiviteit en biologische activiteit van de bodem. Verder bestaat er vanwege de afgenomen infiltratiecapaciteit en doorlatendheid voor water een verhoogd risico voor bodemerosie en verlies van grondstoffen als gevolg van afstroming en denitrificatie (Van den Akker en De Groot, 2008). Bovendien heeft verdichting invloed op de voorraad organische stof en de koolstofvoorraad: bij gelijkblijvende gehalten aan organische stof en koolstof zal de voorraad toenemen naarmate de dichtheid groter wordt.

Zoals blijkt uit de definitie en uitleg van Van den Akker en De Groot (2008), zijn de dichtheid en de indringingsweerstand van de bodem belangrijke variabelen om te bepalen of de bodem verdicht is. Een veelgebruikte methode voor het bepalen van de indringingsweerstand van de bodem is een penetrologger. Deze bestaat uit een pin die met constante snelheid en druk in de bodem wordt gedrukt waarbij de weerstand die ondervonden wordt in de diepte wordt gemeten met een druksensor (Figuur 38). De operationele werkwijze staat beschreven in Bijlage 1, per monsterlocatie zijn vijf steken genomen.

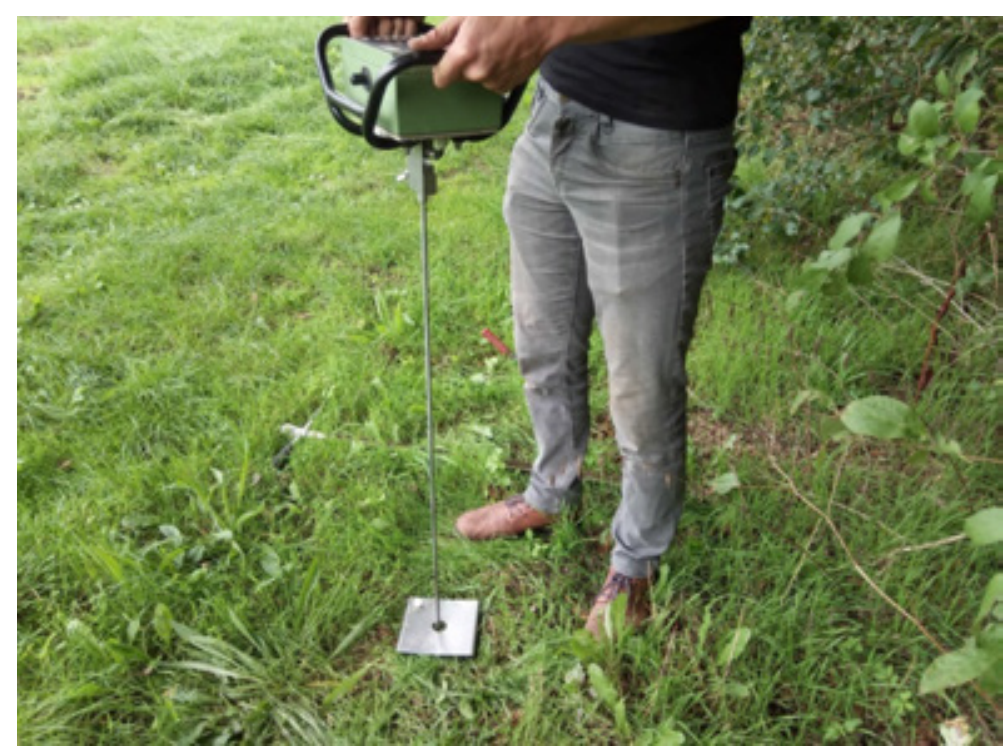

Figuur 38 Penetrologger pin wordt met constante druk en snelheid in de bodem gedrukt.

De indringingsweerstand, zoals gemeten met de penetrologger, is een maat voor de weerstand die wortels ondervinden tijdens de groei. Vastlegging van $\mathrm{CO}_{2}$ in de bodem gaat via planten(wortels). De stelregel is dat wortels bij een indringingsweerstand van meer dan $2 \mathrm{MPa}$ (megapascal) hinder ondervinden, maar nog wel in de bodem kunnen komen. Bij een indringingsweerstand van meer dan $3 \mathrm{MPa}$ is het voor het merendeel van de gewassen niet meer mogelijk om in deze bodem te wortelen (Figuur 39). 


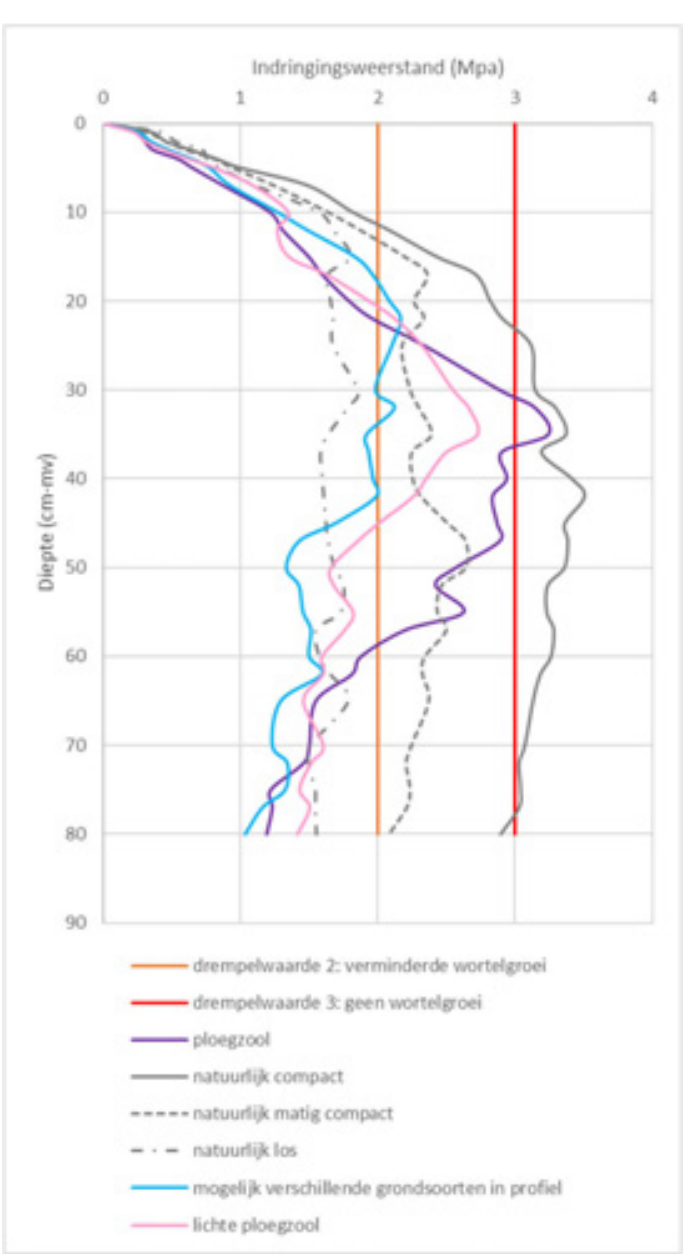

Figuur 39 Voorbeeld van de indringingsweerstanden in de diepte voor verschillende bodemtypen en de drempelwarden voor verminderde en geen wortelgroei.

De indringingsweerstand is afhankelijk van het vochtgehalte, de opbouw van de bodem (alleen zand of klei of zand op veen), maar ook de persoon die de metingen uitvoert. Tijdens de training voor de bemonstering hebben de bemonsteraars van Eurofins deelgenomen aan een studentenonderzoek om de invloed van een persoon op de metingen beter in beeld te krijgen. Figuur 40 geeft een voorbeeld van een profiel zoals gemeten door meerdere personen op één locatie.

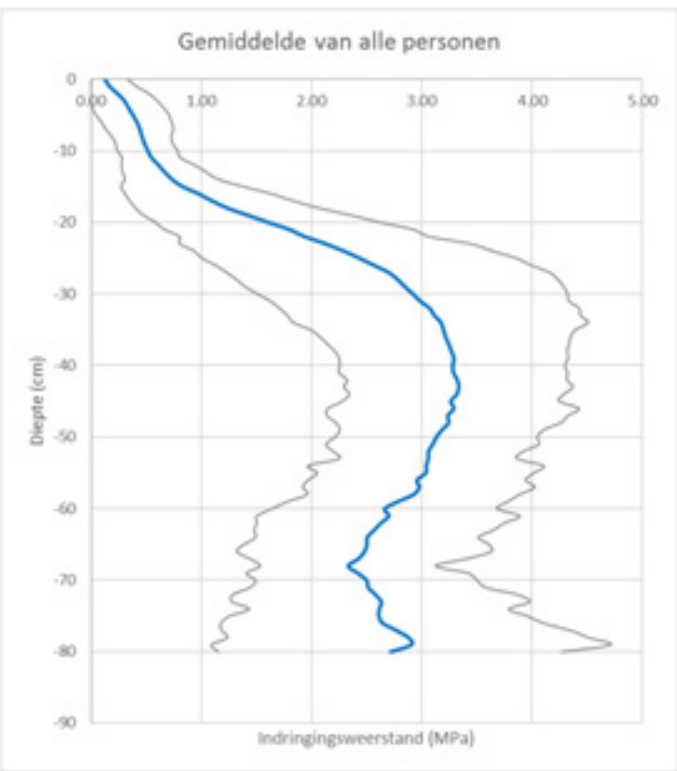

Figuur 40 Gemiddelde, - en + 2xstandaardafwijking penetrologgermetingen van meerdere personen (studentenonderzoek onder bemonsteraars van Eurofins d.d. 4 april 2019). 
De analyse geeft een eerste beeld van bodemverdichting in het landelijke gebied in Nederland. In totaal zijn in 2018 op 998 meetlocaties metingen uitgevoerd die voldoen aan de kwaliteitseisen. Die eisen zijn dat de locatie goed vastgesteld is en dat er onder niet te droge omstandigheden gemeten is. Tijdens de meetcampagne is daarom tegelijk met de penetrologgermetingen het vochtgehalte van de bodem bepaald. Locaties met vochtgehalten in de bodem lager dan $10 \%$ zijn te droog en zijn uit de dataset verwijderd.

Figuur 41 toont het verschil in maximale indringingsweerstanden in de laag $0-60 \mathrm{~cm}$ en de laag 60-80 cm bij een indeling in de zes bodemtypen. Uit de figuur blijkt dat bij akkerland en grasland op minerale gronden (zand, klei, leem) positieve verschillen zijn aangetoond bij een significantieniveau van 0,05 . Ook bij grasland op veen is dit het geval. Deze positieve verschillen kunnen duiden op verdichting. Verschillen zijn niet aantoonbaar bij moerige en veengronden en bij bos en natuur. Figuur 42 toont het ruimtelijke beeld voor Nederland.

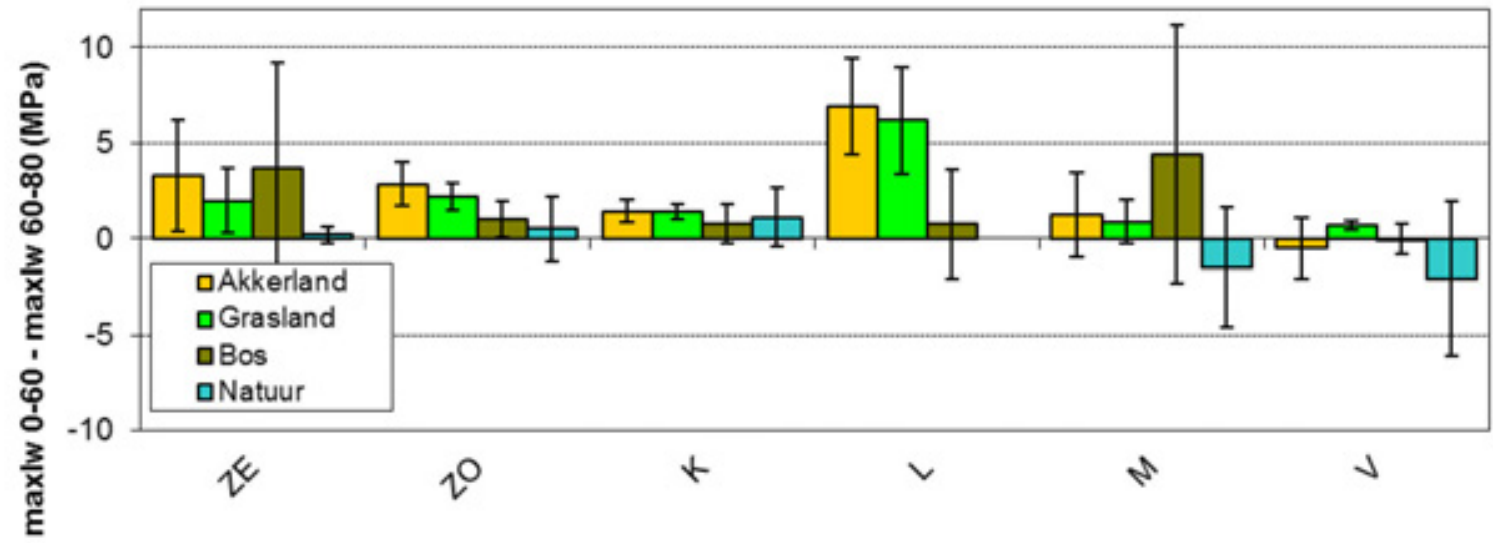

Figuur 41 Gemiddeld verschil tussen de maximale indringingsweerstand tussen 0 en $60 \mathrm{~cm}$ en de maximale indringingsweerstand tussen 60 en $80 \mathrm{~cm}$ (MPa). Een positief verschil kan duiden op verdichting. De error bars geven het 95\%-betrouwbaarheidsinterval aan. Indeling naar landgebruik in 1998.

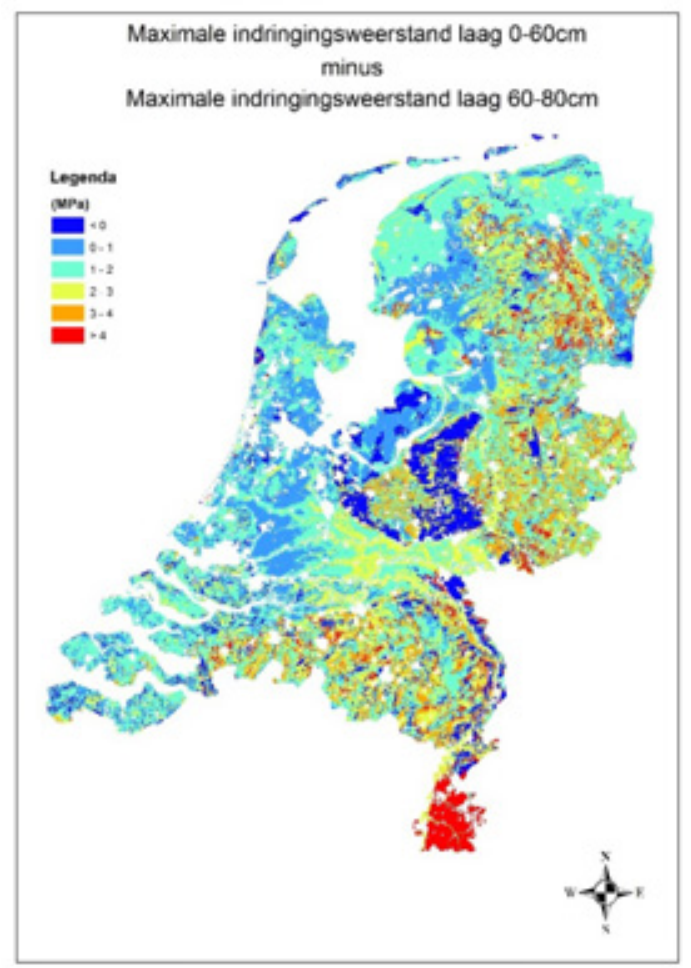

Figuur 42 Gemiddeld verschil tussen de maximale indringingsweerstand tussen 0 en $60 \mathrm{~cm}$ en de maximale indringingsweerstand tussen 60 en $80 \mathrm{~cm}$ (MPa). (Het meetbereik van de meetstang is $80 \mathrm{~cm}$.) 
Figuur 43 toont de mediane diepte waarop een indringingsweerstand van 3 MPa wordt bereikt. Een indringingsweerstand hoger dan $3 \mathrm{MPa}$ wordt als storend voor plantengroei gezien. De mediane diepte waarop deze indringingsweerstand van $3 \mathrm{MPa}$ wordt bereikt, is ongeveer $40 \mathrm{~cm}$ voor alle gronden samen.

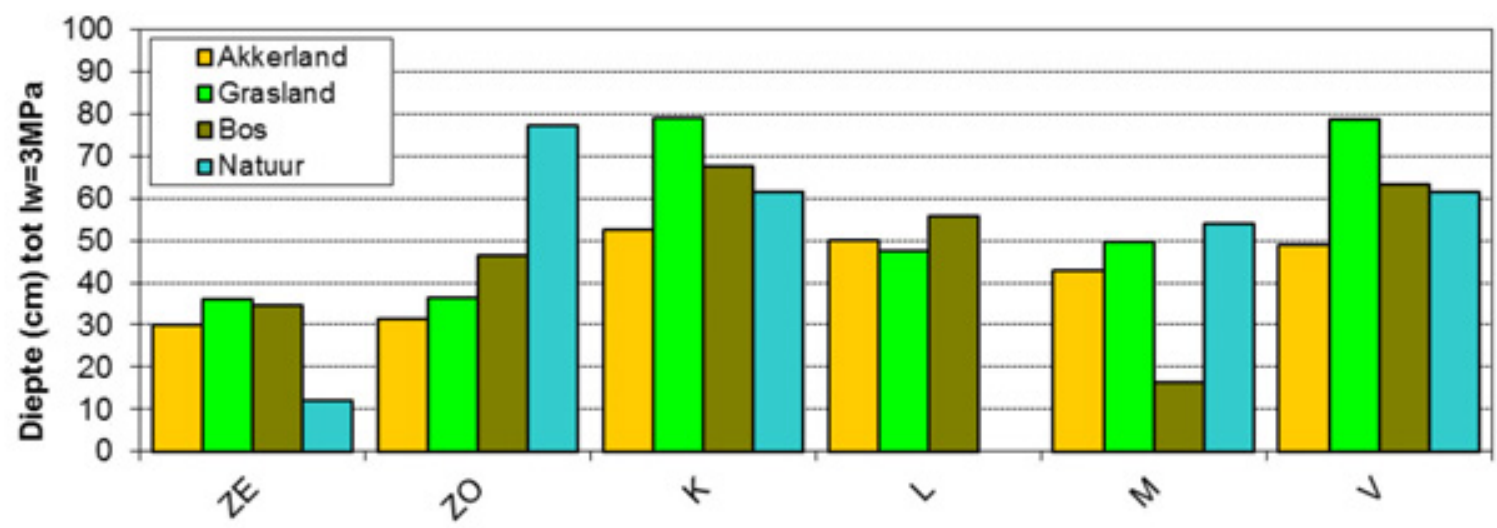

Figuur 43 Mediane diepte tot een indringingsweerstand van $3 \mathrm{MPa}(\mathrm{cm})$. Indeling naar landgebruik in 1998.

Figuur 44 toont de mediane diepte waarop de maximale indringingsweerstand wordt bereikt.

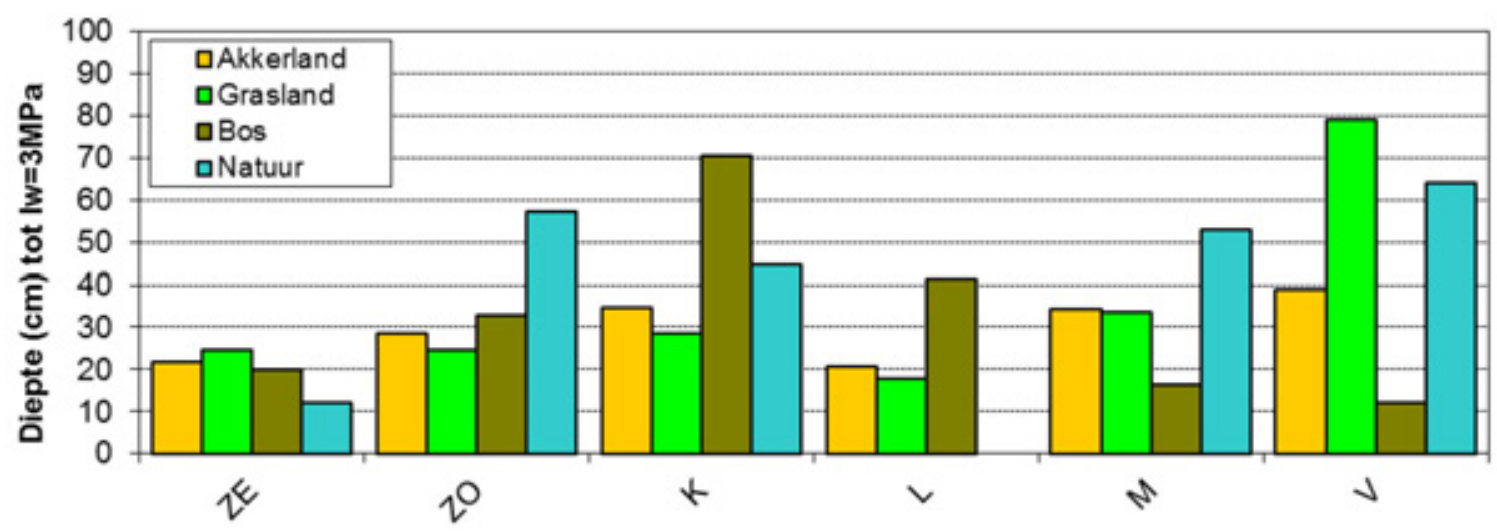

Figuur 44 Mediane diepte tot de maximale indringingsweerstand (cm). Indeling naar landgebruik in 1998.

Figuur 45 geeft de mediane diepte weer waarop de indringingsweerstand groter is dan 3 Mpa en toont de mediane diepte waarop de maximale indringingsweerstand wordt bereikt. Bij de veengronden wordt de indringingsweerstand van $3 \mathrm{Mpa}$ niet in alle gevallen bereikt binnen $80 \mathrm{~cm}$. In Limburg wordt de maximale indringingsweerstand al op $25-35 \mathrm{~cm}$ bereikt. 


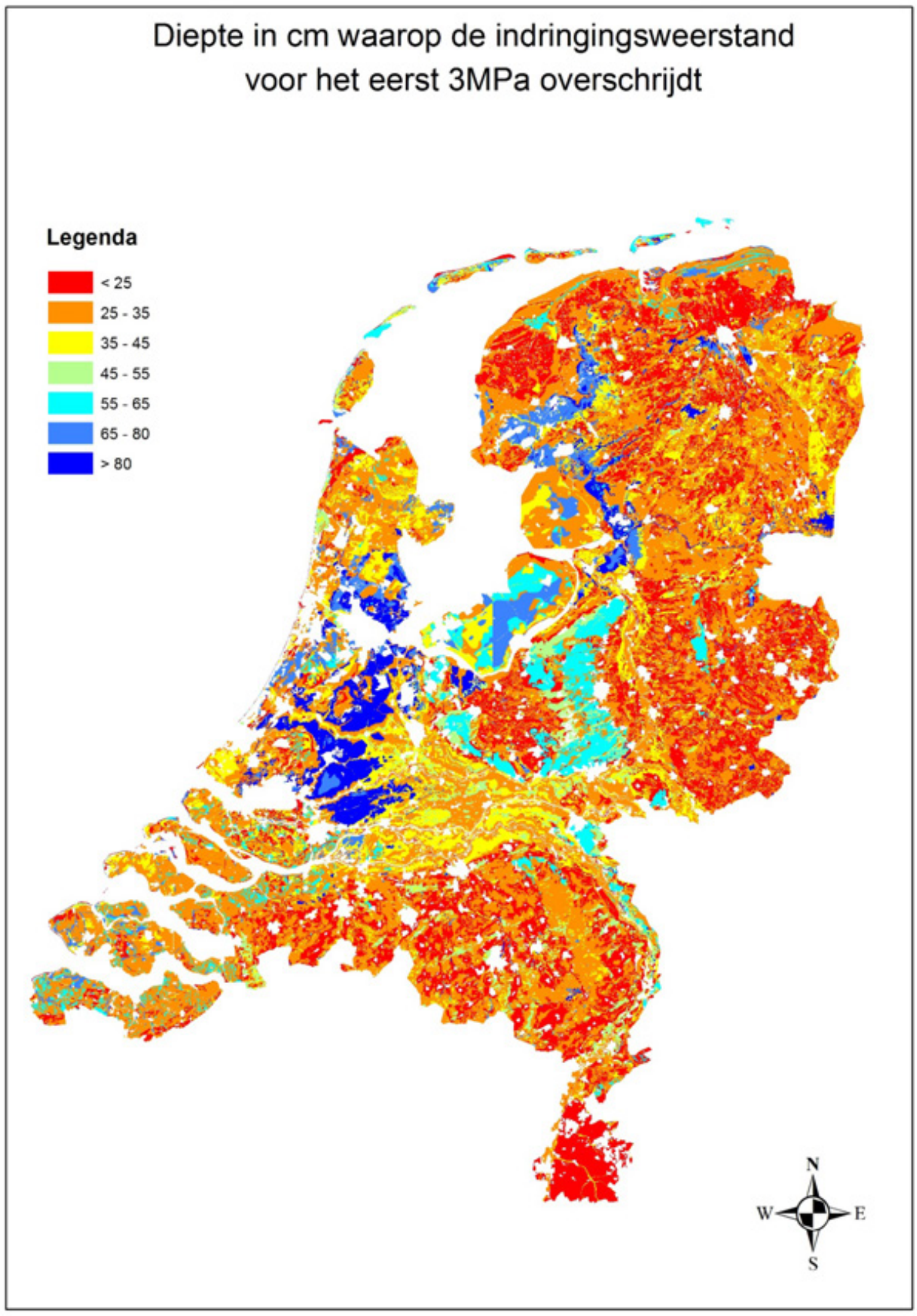

Figuur 45 Diepte waarop een indringingsweerstand van 3 MPa wordt bereikt. 


\section{Discussie}

De resultaten die in het vorige hoofdstuk zijn gepresenteerd, tonen aan dat het gehalte aan organische stof en de koolstofvoorraad in de Nederlandse bodem de laatste twintig jaar zijn afgenomen, zowel in de laag van 0-30 cm als in de laag van $30-100 \mathrm{~cm}$.

Om een verklaring voor deze afname te vinden, moet worden ingezoomd op interessegebieden: gebieden met een bepaalde combinatie van landgebruik en bodemtype. Een beeld van de veranderingen per interessegebied geeft handelingsperspectief. In dit onderzoek zijn gehalten, voorraden en veranderingen daarin geschat voor interessegebieden. De nauwkeurigheid van deze schattingen, uitgedrukt in standaardfouten, geeft aan in welke gebieden de bemonstering moet worden uitgebreid om veranderingen in de koolstofvoorraad nauwkeurig te kunnen monitoren.

\subsection{Gehalte aan organische stof}

Zoals beschreven in hoofdstuk 2 wordt de koolstofvoorraad bepaald aan de hand van de voorraad organische stof. Deze voorraad organische stof wordt berekend op basis van de laagdikte van de bodem, het organische stofgehalte en de dichtheid. Figuur 46 geeft het gehalte aan organische stof voor de bodemlagen 0-30 en 30-100 cm weer.
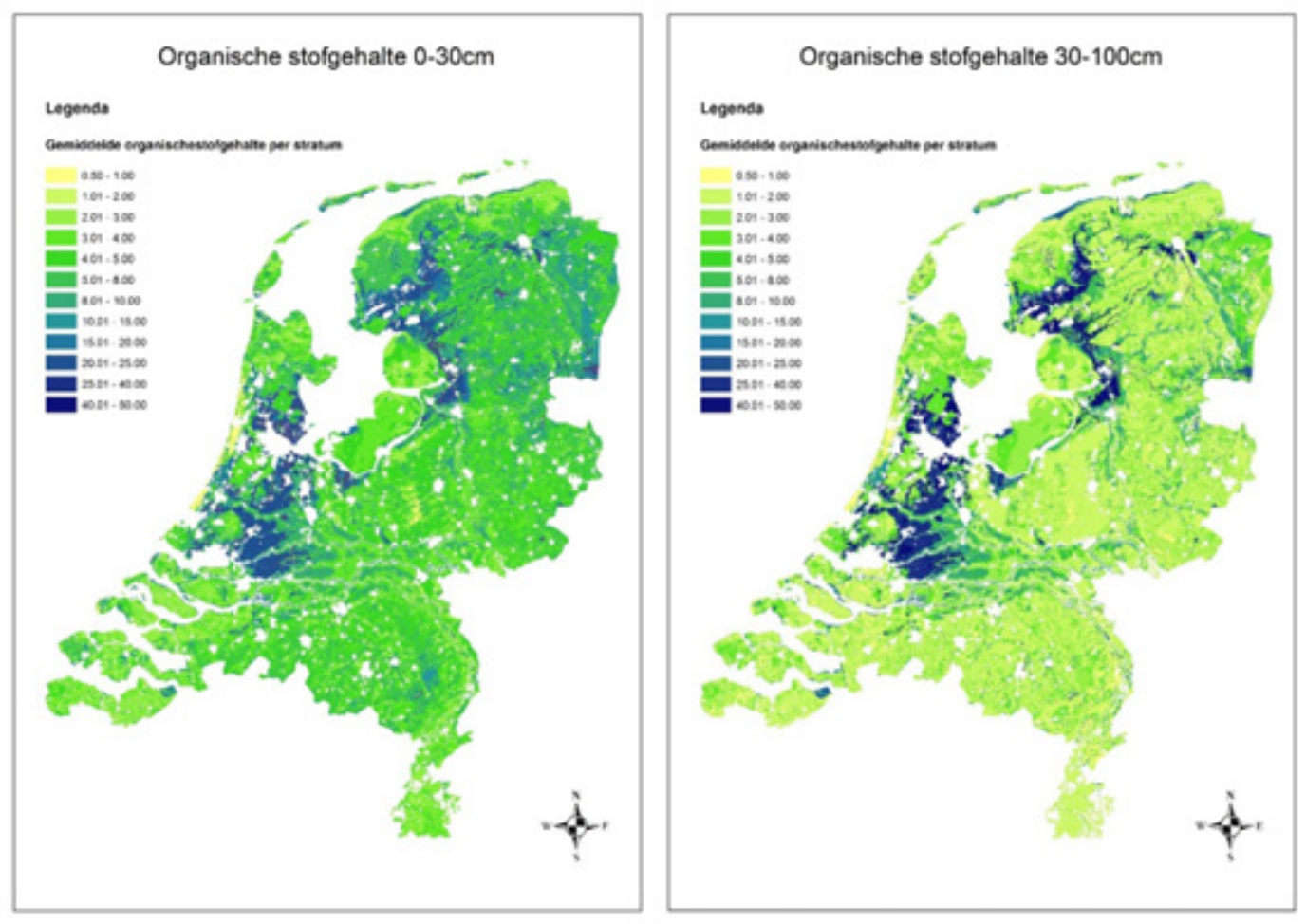

Figuur 46 Gehalte aan organische stof in de laag 0-30 cm (links) en de laag $30-100 \mathrm{~cm}$ (rechts).

In 1998 heeft bemonstering in bodemhorizonten plaatsgevonden. Omdat de bemonstering in 2018 niet door bodemkundigen die horizonten kunnen onderscheiden werd uitgevoerd, is bemonsterd in twee lagen van vaste diepte: $0-30 \mathrm{~cm}$ en $30-100 \mathrm{~cm}$. De gehalten aan organische stof voor deze lagen in 1998 zijn door gewogen middeling berekend uit de gehalten per horizont. Per stratum is een boxplot gemaakt van de verschillen in gehalte aan organische stof (2018-1998). Figuur 47 en Figuur 48 laten zien dat de verandering in voorraad respectievelijk gehalte aan organische stof varieert van deelgebied tot 
deelgebied. Uit Figuur 47 en Figuur 48 kan daarom niet worden afgeleid dat het verschil in voorraad en gehalte aan organische stof systematisch is als gevolg van de berekeningswijze of bepalingsmethode.

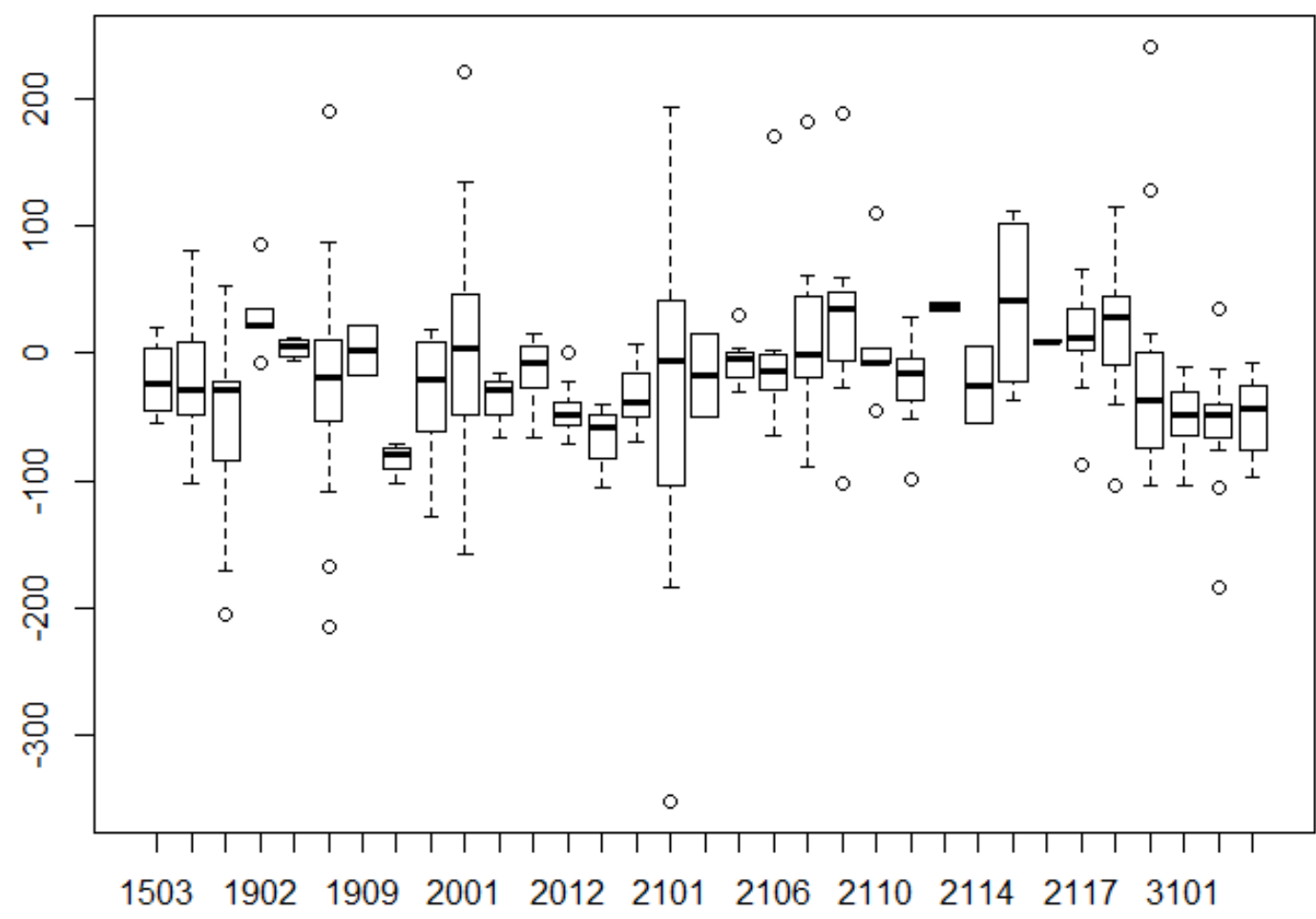

Figuur 47 Boxplot van verschillen in voorraad organische stof in ton/ha in de laag 0-30 cm (20181998), per deelgebied met minerale gronden van de Landelijke Steekproef Kaarteenheden.

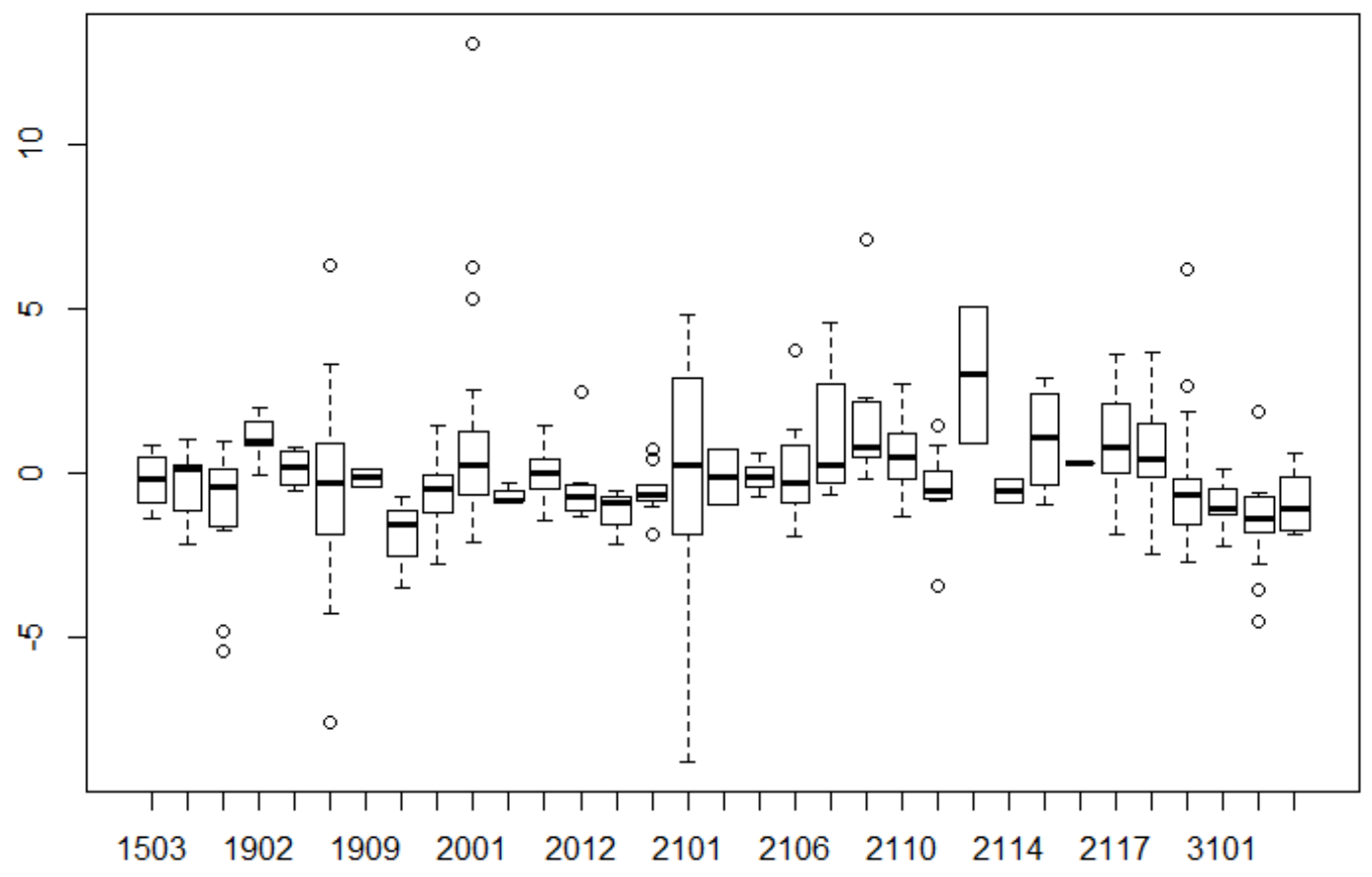

Figuur 48 Boxplot van verschillen in gehalte aan organische stof (\%) in de laag 0-30 cm (20181998), per deelgebied met minerale gronden van de Landelijke Steekproef Kaarteenheden. 
Bij de opzet van de LSK is de indeling in deelgebieden (strata) gebaseerd op de Bodemkaart van Nederland, schaal $1: 50.000$, uit 1998. Inmiddels is deze bodemkaart geactualiseerd en de geactualiseerde kaart laat vooral een afname van het areaal moerige en veengronden zien. Deze afname van moerig materiaal treedt vooral op in de laag van 30 tot $100 \mathrm{~cm}$-maaiveld. Opgemerkt moet worden dat het maaiveld als referentieniveau is gehanteerd, waardoor een afname van de koolstofvoorraad niet is vast te stellen in gronden waarin veen- en moerige lagen zowel twintig jaar geleden als nu tot dieper dan $1 \mathrm{~m}$ beneden maaiveld doorlopen. Om voor deze gronden afnames van de koolstofvoorraad vast te stellen, is waterpassing van het maaiveld ten opzichte van NAP nodig.

\subsection{Invloed veranderend landgebruik}

Een mogelijke verklaring voor de waargenomen verandering van de koolstofvoorraad in de Nederlandse bodem is veranderend landgebruik. In de huidige analyse is uitgegaan van het landgebruik zoals dat ten tijde (1990-2001) van de LSK in het veld is waargenomen.

Er kan worden aangenomen dat niet alleen het landgebruik, maar ook het landmanagement is veranderd gedurende de afgelopen twintig jaar. Om de verandering in de waargenomen koolstofvoorraad te verklaren, is het nodig om de landgebruiksgeschiedenis en het landmanagement in de afgelopen 20 jaar te analyseren. In de landgebruiksanalyse over de afgelopen twintig jaar lijkt een onderscheid zinnig tussen structurele (definitieve) veranderingen in landgebruik (bijvoorbeeld landbouw $\rightarrow$ natuur) en rotaties bij (melkveehouderij)bedrijven tussen gras, maïs en overige akkerbouwgewassen. Daarnaast is aandacht voor temperatuur, neerslag maar ook voor vergraven van gronden belangrijk. Intensieve grondbewerking zorgt namelijk voor zuurstofrijke omstandigheden waarbij organische stof oxideert. Hiermee heeft vergraven, zowel ophogen en afgraven als diepe grondbewerking, invloed op de koolstofvoorraad.

\subsection{Bodemdichtheid en indringingsweerstanden}

Om een schatting te maken van de verandering van de koolstofvoorraad in Nederland is gebruikgemaakt van de gemeten dichtheid van de betreffende bodem. Om het gemeten organische stofgehalte om te zetten naar een koolstofvoorraad wordt namelijk vermenigvuldigd met de bodemdichtheid. In 2018 is deze dichtheid via het volume van de guts bepaald (paragraaf 2.2). De gemeten dichtheden zijn op sommige meetpunten heel hoog of juist heel laag (Figuur 49 en Figuur 50). Op minerale gronden wordt op de laag 0-30 cm voor een aantal locaties een erg lage dichtheid gemeten, wat mogelijk een gevolg is van de droogte die in 2018 in Nederland optrad. Door de droogte raakte de guts mogelijk niet altijd goed gevuld met grond. 

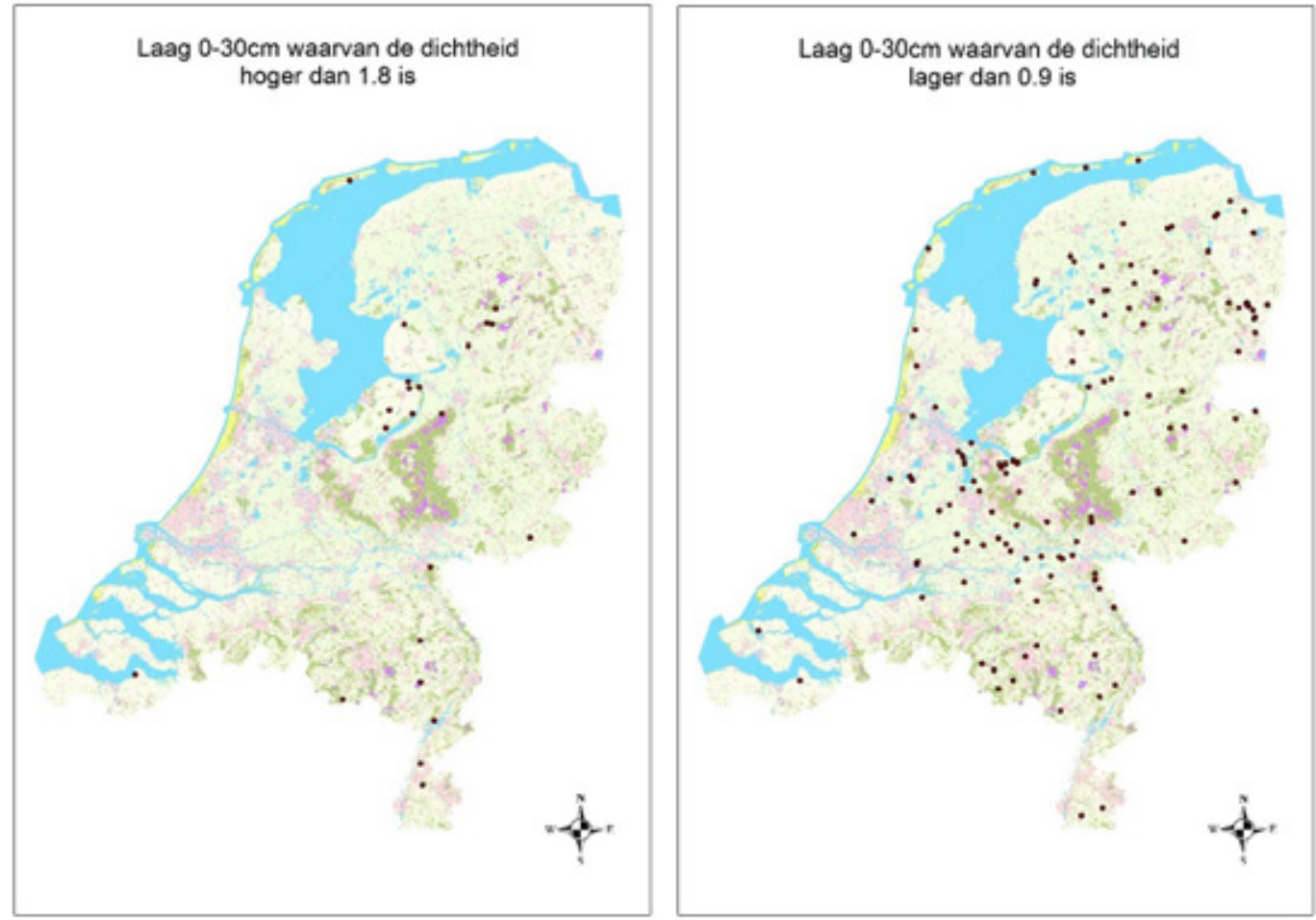

Figuur 49 Meetpunten met een heel hoge (links) of heel lage dichtheid (rechts) in de laag 0-30 cm.
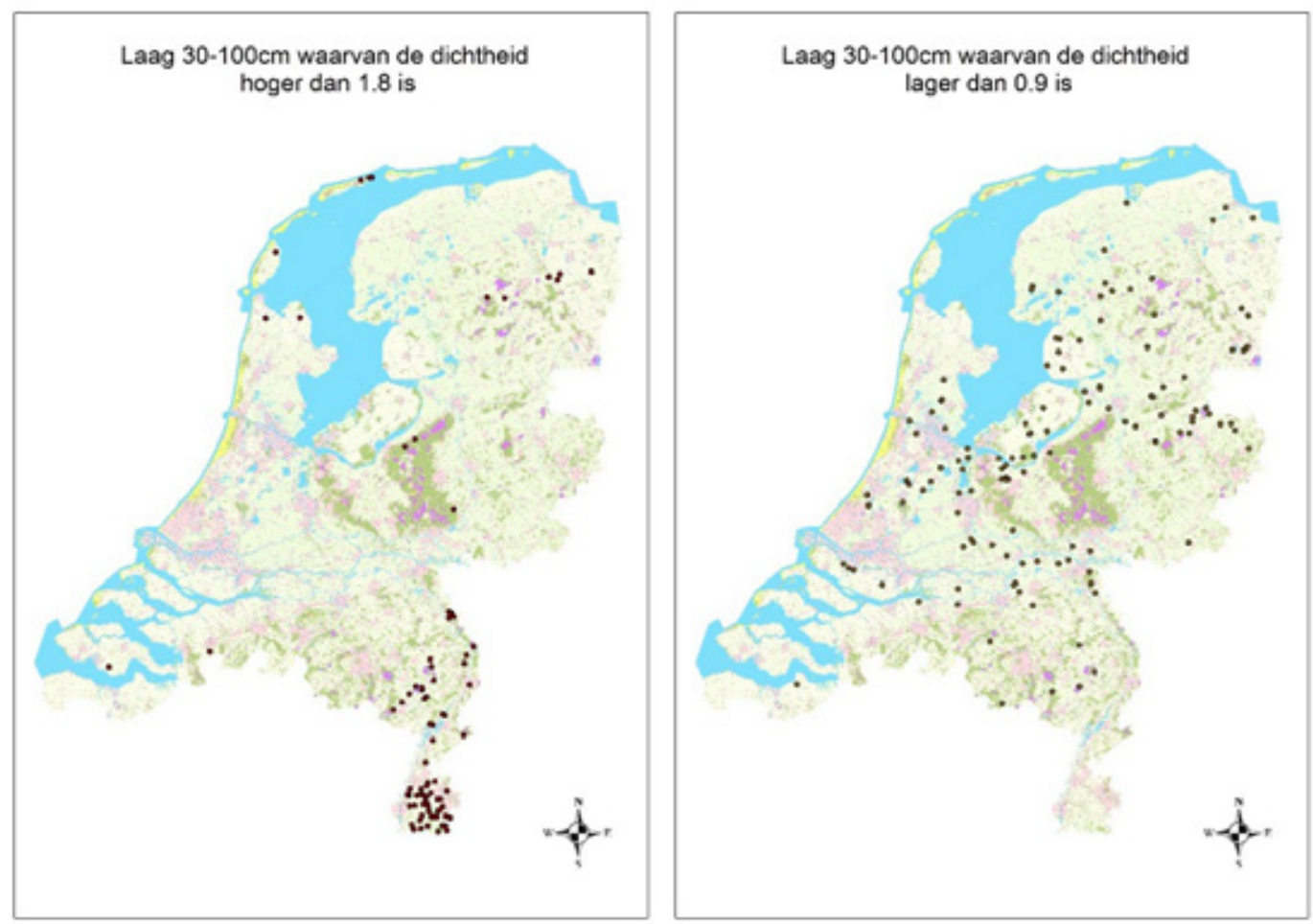

Figuur 50 Meetpunten met een heel hoge (links) of heel lage dichtheid (rechts) in de laag $30-100 \mathrm{~cm}$.

\section{Invloed bepalingsmethode}

Uit de analyses blijkt dat de dichtheid van de bodem gemiddeld zou zijn afgenomen tussen circa 1998 en 2018. Tijdens de LSK zijn geen dichtheden gemeten, maar afgeleid uit pedotransferfuncties, terwijl in 2018 dichtheden zijn gemeten aan monsters die met een guts zijn gestoken (Visschers en Marsman, 1991). Als de afname in dichtheid systematisch zou zijn als gevolg van dit verschil in bepalingsmethode, dan zou de afname ongeveer even groot moeten zijn in alle deelgebieden (strata) 
van de LSK. Met een boxplot (Figuur 51) is gecontroleerd of er sprake is van een systematisch verschil. In Figuur 51 kan geen systematisch verschil worden waargenomen, wat het minder aannemelijk maakt dat verschil in bepalingsmethode een verklaring is voor de gevonden afname in gemiddelde dichtheid.

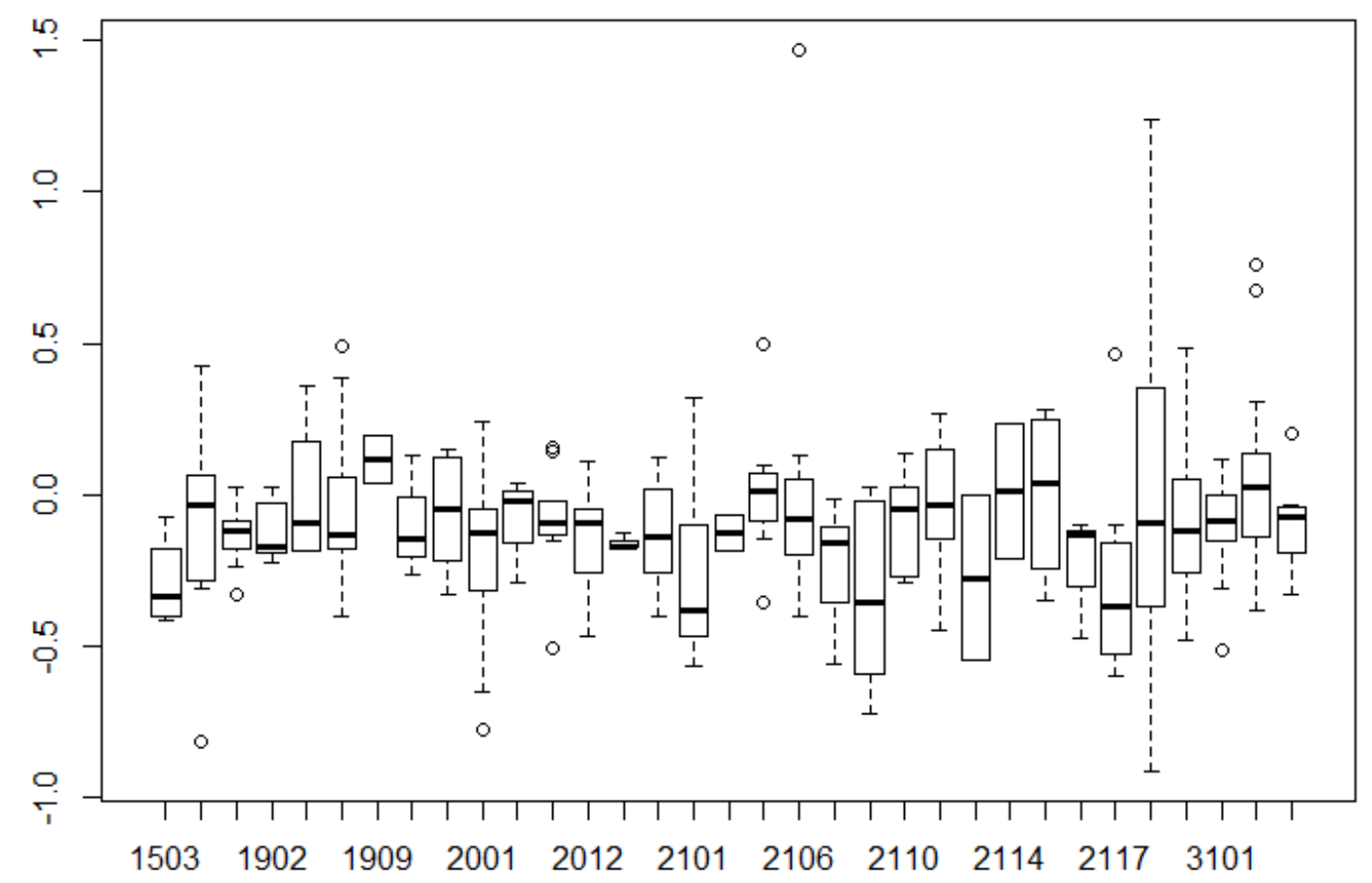

Figuur 51 Boxplot van verschillen in dichtheid $\left(\mathrm{g} / \mathrm{cm}^{3}\right)$ in de laag 0-30 cm (2018-1998), per deelgebied met minerale gronden van de Landelijke Steekproef kaarteenheden.

\section{Verwijderen uitbijters}

Om de koolstofvoorraad in de bodem zo nauwkeurig mogelijke te schatten, zijn gemeten dichtheden die buiten het bereik van dichtheden uit Wösten et al. (2001) vallen als 'uitbijter' beschouwd en bij de verdere analyse buiten beschouwing te laten.

Figuur 52 geeft de gemiddelde dichtheden per deelgebied van de LSK weer, waarbij uitbijters buiten beschouwing zijn gelaten. Opmerkelijk zijn de hoge dichtheden in de laag van 30 tot $100 \mathrm{~cm}$ in ZuidLimburg. Een van de monsternemers rapporteerde het volgende:

Over het algemeen was het rond de $45 \mathrm{~cm}$ zo hard als beton, meestal tot een centimeter of 60 a 75 . Wellicht dat het daarin zit? 


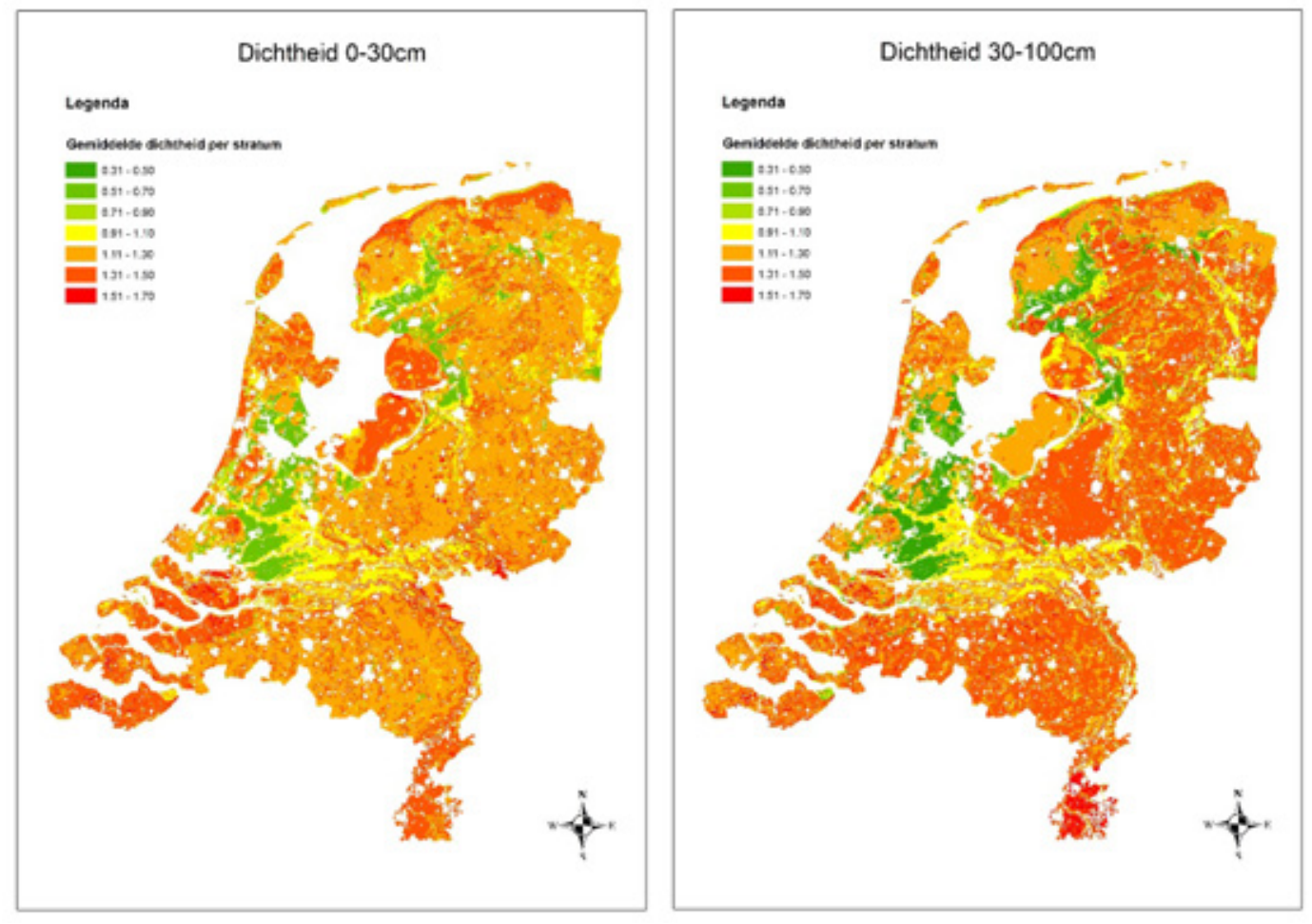

Figuur 52 Gemiddelde dichtheden per deelgebied voor de laag 0-30 cm (links) en laag $30-100 \mathrm{~cm}$ (rechts), berekend uit gemeten dichtheden, na verwijdering van uitbijters.

De resultaten laten een grote variatie in gemeten dichtheid zien en gemiddeld genomen een afname ten opzichte van circa 1998. Mogelijk heeft de droogte van 2018 de gemeten dichtheid beïnvloed. Het is daarom aan te bevelen om terug te keren naar een selectie van veldlocaties om daar opnieuw de dichtheid vast te stellen. Tevens is het aan te bevelen om dan de gutsmethode te vergelijken met de gravimetrische methode met $100 \mathrm{cc}$-ringen en de nieuwe dichtheidssensor (paragraaf 4.5). Ook dienen de aldus verkregen dichtheidsgegevens gebruikt te worden bij de verklaring van de waargenomen indringingsweerstanden, rekening houdend met het huidige landgebruik.

\subsection{Koolstofratio}

In de LULUCF-rapportage (Lesschen et al., 2012) wordt tot nu toe een defaultwaarde van 0,5 (koolstofratio) gehanteerd om het gehalte aan organische stof om te rekenen naar het koolstofgehalte. Bij de laboratoriumanalyses van de monsters die in 2018 op de locaties van de LSK zijn verzameld, is naast het gehalte aan organische stof, via de gloeiverliesmethode, ook het gehalte koolstof-elementair bepaald. Daardoor is het mogelijk om voor elk bemonsteringspunt de koolstofratio te bepalen en deze te vergelijken met de factor die gebruikt wordt.

Uit een eerste berekening volgt dat de koolstofratio voor de laag 0-30 cm gemiddeld 0,54 bedraagt, met een standaardfout van 0,0030. Dit is dus significant hoger dan 0,5. Er is spreiding en er zijn uitschieters, zie Figuur 53. Er dient nog kritisch naar de waarden, waaronder de uitschieters, te worden gekeken. De vraag is of we op basis van de huidige laboratoriummetingen wel of niet kunnen afwijken van de huidige defaultwaarde van 0,5 die momenteel voor de LULUCF-rapportage wordt gehanteerd, of dat deze factor nog naar bodemtype gespecificeerd kan worden. Voor de uiteindelijke LULUCFrapportage zal de koolstofratio echter slechts een beperkt effect hebben, aangezien het om veranderingen in koolstofvoorraad gaat waarbij dezelfde koolstofratio gehanteerd wordt voor de verschillende perioden.

De verhouding tussen koolstof en stikstof is een belangrijke indicator voor het gemak waarmee organische stof kan worden afgebroken. Deze metingen zijn ook beschikbaar en kunnen ook worden geanalyseerd. 


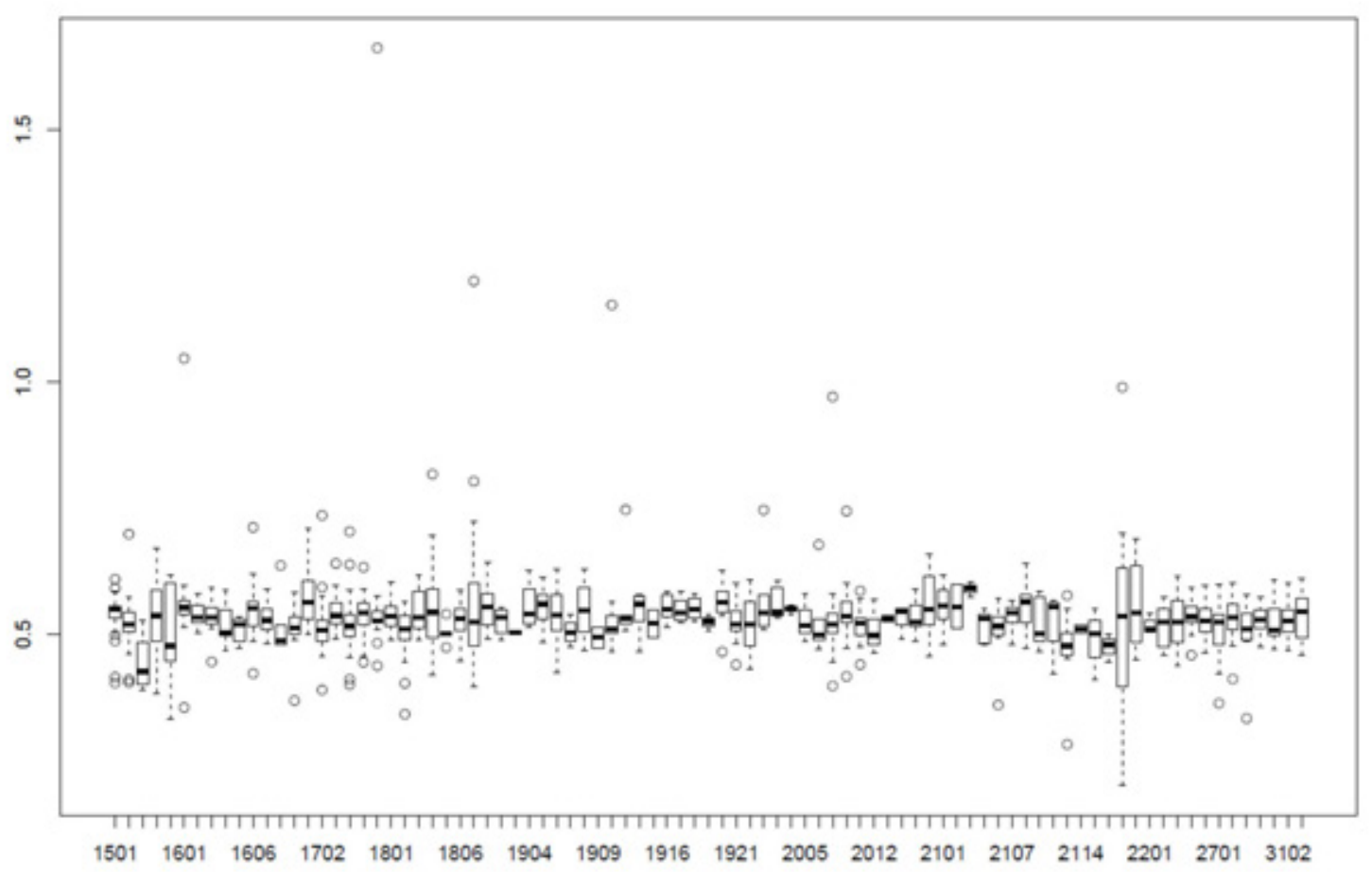

Figuur 53 Boxplot van gemeten koolstofratio (2018), per deelgebied van de Landelijke Steekproef kaarteenheden.

\subsection{Monitoring}

De gerapporteerde resultaten geven de huidige koolstofvoorraad in de Nederlandse bodem weer en ook de verandering ten opzichte van twintig jaar geleden. Zoals door het ministerie van LNV gewenst, beschrijven de resultaten hiermee de uitgangssituatie voor de LULUCF-rapportage voor 2020 aan de UNFCCC. Als vervolg hierop voorziet LNV de noodzaak tot toekomstige monitoring van de bodemkoolstofvoorraad in cycli van drie tot vijf jaar.

\section{Uitbreiding LSK}

Om een landsdekkend beeld van de koolstofvoorraden in de bodem te kunnen bepalen, is uitbreiding van de steekproef 2018 nodig. Door bijvoorbeeld bebouwing, ontoegankelijkheid of andere veranderingen in landgebruik zijn er meetpunten vervallen (Figuur 54), waardoor deelgebieden (strata) met geen of slechts één punt zijn afgevallen. Daarnaast kan het noodzakelijk zijn om de steekproef aan te passen indien het ministerie van LNV meer informatie van specifieke deelgebieden wenst te hebben, bijvoorbeeld voor bepaalde land- en bodemtypen. Door de serie meetpunten up-to-date te maken, kan een nauwkeurige, nieuwe bepaling van de koolstofvoorraad in de periode 2020-2030 plaatsvinden die kan worden vergeleken met de opnames in 1998 en 2018. 


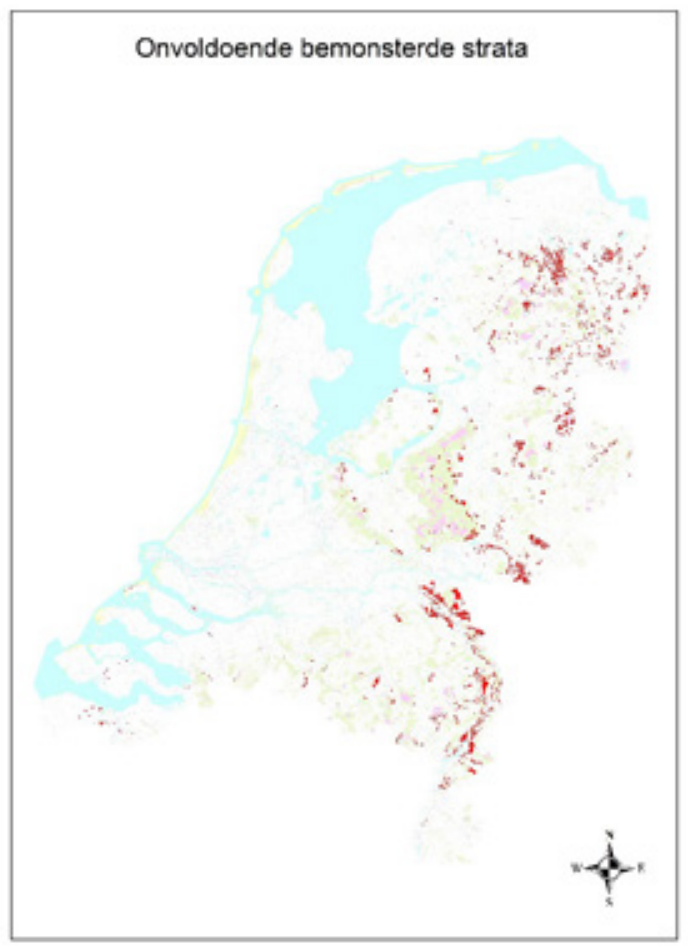

Figur 54 Deelgebieden die niet zijn meegenomen in de berekeningen.

\section{Nieuwe analysemethoden}

Om de koolstofvoorraad in de bodem te bepalen en te vergelijken met de koolstofvoorraad in de periode 1990-2001, zijn de methodieken zo veel mogelijk op elkaar afgestemd. Daarom is ervoor gekozen om de monsters met klassieke laboratoriummethoden te analyseren.

Nabij-infraroodreflectie (NIR) is een techniek om het gehalte aan organische stof in de bodem te meten (voor een overzicht, zie Knotters et al., 2017). Ten opzichte van de klassieke methode heeft NIR een kortere doorlooptijd en lagere kosten. De monsters die in 2018 op de LSK-locaties zijn verzameld, zijn zowel met klassieke laboratoriummethoden als met NIR geanalyseerd voor de bepaling van de totale hoeveelheid koolstof en de gehalten aan organische stof en organische koolstof in de bodem. Deze dataset leent zich voor een vergelijking tussen klassieke laboratoriummethoden en NIR. Naast NIR wordt ook mid-infrarode reflectie (MIR) ontwikkeld en toegepast. Ook de toepasbaarheid van deze methode dient nader te worden onderzocht en Bijlage 3 geeft een overzicht van beschikbare, nieuwe meettechnieken.

Als alternatief voor de gravimetrische methode om de dichtheid van de bodem te bepalen, is een methode ontwikkeld die gebaseerd is op een actieve gammastraling veldmeting (RhoC) in combinatie met een bodemvochtmeting (Jacobs et al., 2009; Jacobs, 2011). In 2018 zijn, in opdracht van het ministerie van LNV, een RhoC en vochtsensor aangeschaft voor veldmetingen. Het is aan te bevelen om de toepasbaarheid van deze nieuwe dichtheidssensor bij de bepaling van dichtheden te onderzoeken.

\subsection{Kennisvragen}

De resultaten geven de huidige gehalten aan organische stof, dichtheden en koolstofvoorraden in de Nederlandse bodem weer en de veranderingen hierin ten opzichte van 20 jaar geleden. De resultaten van deze meetcampagne bieden een goede uitgangssituatie voor toekomstige monitoring voor de post2020-LULUCF-rapportage. De resultaten die tot nu toe zijn verkregen roepen echter ook vijf concrete kennisvragen op. Beantwoording van deze vijf vragen is van belang om van het verleden te leren en om toekomstige meetcampagnes in de periode 2020-2030 nog doelmatiger en efficiënter uit te voeren. Hiermee wordt het ministerie van LNV in staat gesteld om de impact van klimaatslim landgebruik en de bijdrage aan de $\mathrm{CO}_{2}$-reductiedoelstelling vanaf 2018 te monitoren. 
Het betreft de volgende kennisvragen:

- Wat is de invloed van veranderend landgebruik? Op landelijke schaal kon geen verandering van gehalten aan organische stof in de Nederlandse bodem worden aangetoond, maar wel een verandering van de koolstofvoorraad (Tabel 2). Voor de 24 combinaties van landgebruik en bodemtype waren veranderingen in koolstofvoorraad vaak niet aantoonbaar. In de huidige analyse is echter uitgegaan van het landgebruik zoals dat ten tijde (1994-2001) van de LSK in het veld is waargenomen. Om verandering te verklaren, is het nodig om naast de dichtheden ook de landgebruiksgeschiedenis en het landmanagement in de afgelopen twintig jaar te analyseren. Op basis van veldwaarnemingen is er ook informatie over het landgebruik in 2018. Hieruit zou al een eerste indicatie van de invloed van landgebruik op de koolstofvoorraad in de bodem kunnen worden afgeleid. In de landgebruiksanalyse lijkt een onderscheid zinnig tussen structurele (definitieve) veranderingen in landgebruik (bijvoorbeeld landbouw $\rightarrow$ natuur) en rotaties bij (melkveehouderij)bedrijven tussen gras, maïs en overige akkerbouwgewassen. Deze gegevens zouden kunnen worden afgeleid uit bijvoorbeeld Basisregistratie Percelen of via Eurofins (MijnPercelen).

- Wat is de invloed van diepe grondbewerking op de koolstofvoorraad? Tot nu toe is een indeling in bodemtypen gebruikt, ongeacht of een bodem diep bewerkt is. Profielen kunnen echter zijn gediepploegd, gemengwoeld, omgekeerd, afgegraven of opgehoogd. Vergraven, zowel ophogen en afgraven als diepe grondbewerking, heeft invloed op de koolstofvoorraad. Intensieve grondbewerking zorgt onder andere voor zuurstofrijke omstandigheden waarbij organische stof oxideert. Kennis over de historie van diepe grondbewerking is dus belangrijk om veranderingen in gehalten aan organische stof en in koolstofvoorraden te kunnen verklaren.

- Wat is de invloed van veranderingen in bodemdichtheid, zoals verdichting? Om het gemeten gehalte aan organische stof om te zetten naar een koolstofvoorraad, wordt vermenigvuldigd met de bodemdichtheid. De resultaten laten een grote variatie aan bodemdichtheden zien en een grote invloed van de dichtheid op de berekende koolstofvoorraad. De dichtheden die in 2018 aan monsters zijn bepaald die met een guts waren gestoken, weken af van de dichtheden die voor de periode 19942001 waren berekend met pedotransferfuncties. Het is van belang dat de dichtheid en veranderingen daarin nauwkeurig worden vastgesteld. Mogelijk heeft de droogte van vorig jaar tijdens de bemonstering geleid tot een vertekend beeld in de dichtheid en daarmee in de koolstofvoorraad. Ook kan een rol spelen dat bij de gutsmethode de bodem vanaf maaiveld is bemonsterd, terwijl bij metingen met ringen doorgaans niet vanaf maaiveld, maar dieper wordt bemonsterd. Het is daarom aan te bevelen om terug te keren naar een selectie van veldlocaties om daar opnieuw de dichtheid vast te stellen. Daarnaast dienen de dichtheden die met de gehanteerde gutsmethode zijn bepaald, te worden vergeleken met dichtheden die zijn bepaald volgend de gravimetrische methode met $100 \mathrm{cc}-$ ringen en nieuwe meettechnieken, zoals een dichtheidssensor (Bijlage 3).

- Welke koolstofratio moet worden gehanteerd? Momenteel wordt, in de LULUCF-rapportage, een defaultwaarde van 0,5 (koolstofratio) gehanteerd om het gehalte aan organische stof (SOM) om te rekenen naar het koolstofgehalte (SOC). Er wordt ook wel een factor van 0,58 gehanteerd (de zogeheten Van-Bemmelenfactor). De hoogte van de factor heeft uiteraard grote invloed op de berekende koolstofvoorraad. De laboratoriummetingen die uitgevoerd zijn in 2018, laten gemiddeld een hogere ratio dan 0,5 voor Nederland zien. Voor de laag $0-30 \mathrm{~cm}$ is de ratio gemiddeld 0,54 en voor de laag $30-100 \mathrm{~cm}$ is de ratio 0,51 . Hierdoor is er direct invloed op het berekende koolstofgehalte. Uit nadere analyses blijkt dat, door de grote variatie, de huidige koolstofratio eigenlijk niet algemeen toepasbaar is voor Nederlandse bodems en dat verder onderzoek nodig is. De vraag is of we op basis van de huidige laboratoriummetingen wel of niet kunnen afwijken van de huidige defaultwaarde van 0,5 die momenteel voor de LULUCF-rapportage wordt gehanteerd.

- Met welke meetinspanning moet de monitoring worden voortgezet? Om een landsdekkend beeld van de koolstofvoorraden in de bodem te kunnen bepalen, is uitbreiding van de steekproef 2018 nodig. Door bijvoorbeeld bebouwing zijn er meetpunten vervallen. Daarnaast kan het noodzakelijk zijn om bij bepaalde combinaties van landgebruik en bodemtype de steekproef uit te breiden voor een nauwkeuriger schatting van gehalten aan organische stof, koolstofvoorraden en veranderingen daarin. Door de serie meetpunten up-to-date te maken, kan een nauwkeurige, nieuwe bepaling van de koolstofvoorraad in de periode 2020-2030 plaatsvinden die kan worden vergeleken 
met de opnames in 1998 en 2018.

Nabij-infrarood-reflectie (NIR) is een steeds gangbaardere techniek om koolstof in de bodem te meten. In 2018 zijn naast de klassieke data van alle monsterpunten (gebruikt voor de vergelijking 1998) ook NIR-data beschikbaar. Deze datasets lenen zich voor een vergelijking tussen klassiek en NIR, zodat in de toekomst NIR-data gebruikt kunnen worden voor monitoring van de koolstofvoorraden in de bodem. Naast NIR wordt ook mid-infrarode reflectie (MIR) verder ontwikkeld en toegepast. Vorig jaar is een MIR-apparaat aangeschaft. Het is aan te bevelen om zowel NIR als MIR te vergelijken met de klassieke methode qua nauwkeurigheid, toepasbaarheid en betaalbaarheid (Bijlage 3). 


\section{Literatuur}

Akker, van den J.J.H. en W.J.M. de Groot, 2008. Een inventariserend onderzoek naar de ondergrondverdichting van zandgronden en lichte zavels. Wageningen, Alterra, rapport 1450.

Fernández-Ugalde, O., A. Orgiazzi, A. Jones, E. Lugato en P. Paganos, 2017. LUCAS 2018 - SOIL COMPONENT: Sampling Instructions for Surveyors. Luxembourg, European Commission, JRC105923 JRC Technical Report JRC105923.

Finke, P.A., J.J. de Gruijter en R. Visschers, 2001. Status 2001 Landelijke Steekproef Kaarteenheden en toepassingen; Gestructureerde bemonstering en karakterisering Nederlandse bodems. Wageningen, Alterra, rapport 389.

Jacobs, W., 2011. Sand-mud erosion from a soil mechanical perspective. PhD thesis, Technische Universiteit Delft.

Jacobs, W., M. Eelkema, H. Limburg en J. Winterterp, 2009. A new radiometric instrument for in situ measurements of physical sediment properties. Marine \& Freshwater Research 60: 727-736.

Knotters, M., F.M. van Egmond, G. Bakker, D.J.J. Walvoort en F. Brouwer, 2017. A selection of sensing techniques for mapping soil hydraulic properties. Wageningen, Alterra, WENR-Report 2853.

Kuikman, P.J., Groot, W. de, Hendriks, R., Verhagen, J. en de Vries, F. 2003. Stocks of C in soils and emissions of $\mathrm{CO} 2$ from agricultural soils in the Netherlands. Wageningen, Alterra-rapport 561.

Lesschen, J.P., H.I.M. Heesmans, J.P. Mol-Dijkstra, A.M. van Doorn, E. Verkaik, I.J.J. van den Wyngaert and P.J. Kuikman. 2012. Mogelijkheden voor koolstofvastlegging in de Nederlandse landbouw en natuur. Wageningen, Alterra-rapport 2396. http://edepot.wur.nl/247683.

Stoner, E.R. en M.F. Baumgardner, 1981. Characteristic variations in reflectance of surface soils. Soil Science Society of America 45(6): 1161-1165.

Visschers, R. en B.A. Marsman, 1991. Meten van de dichtheid van de grond met een gutsboor. Landinrichting 31(3): 33-35.

Wösten, J.H.M., G.J. Veerman, W.J.M. de Groot en J. Stolte, 2001. Waterretentie- en doorlatendheidskarakteristieken van boven- en ondergronden in Nederland: de Staringreeks. Vernieuwde uitgave 2001. Wageningen, Alterra-rapport 153. 


\section{Bijlage 1 Wijze van bemonstering}

\section{Keuze bemonsteringsmethode}

Grondbemonsteringen kunnen op verschillende manieren worden uitgevoerd. Elke methode kent vooren nadelen in bijvoorbeeld kwaliteit, tijd, kosten etc. en kan uiteenlopende doelen dienen. Voor dit project is, onder de bijbehorende randvoorwaarden, gekozen voor de onderstaande bemonsteringsmethode.

\section{Bemonsteringsmethode}

De LUCAS 2018 soil component instructions van JRC (Fernández-Ugalde et al., 2017) beschrijft een methode waarbij op elke locatie in het midden en daarna in een cirkel eromheen in totaal vijf steken grond worden gemengd tot een monster. De vier steken om het middelpunt liggen op $2 \mathrm{~m}$ afstand en in de vier windrichtingen N, Z, O en W (zie Figuur B1.1). De bodem wordt over twee dieptes bemonsterd: 0-30 cm en 30-100 cm. Deze mengmonsters worden vervolgens geanalyseerd in het lab. Om de volledige diepte te bemonsteren, wordt gebruikgemaakt van een steekguts (Visschers en Marsman, 1991), zoals te zien is in Figuur B1.2. De guts heeft een lengte van $100 \mathrm{~cm}$ met een diameter van $3 \mathrm{~cm}$. De inhoud, tot de snijrand, is $4.44 \mathrm{~cm}^{3}$ per $\mathrm{cm}$. Door het bemonsterde volume secuur vast te stellen, kan na drogen van de grond ook de volumieke dichtheid worden berekend. Deze grond kan ook gebruikt worden voor analyse van het koolstofgehalte.
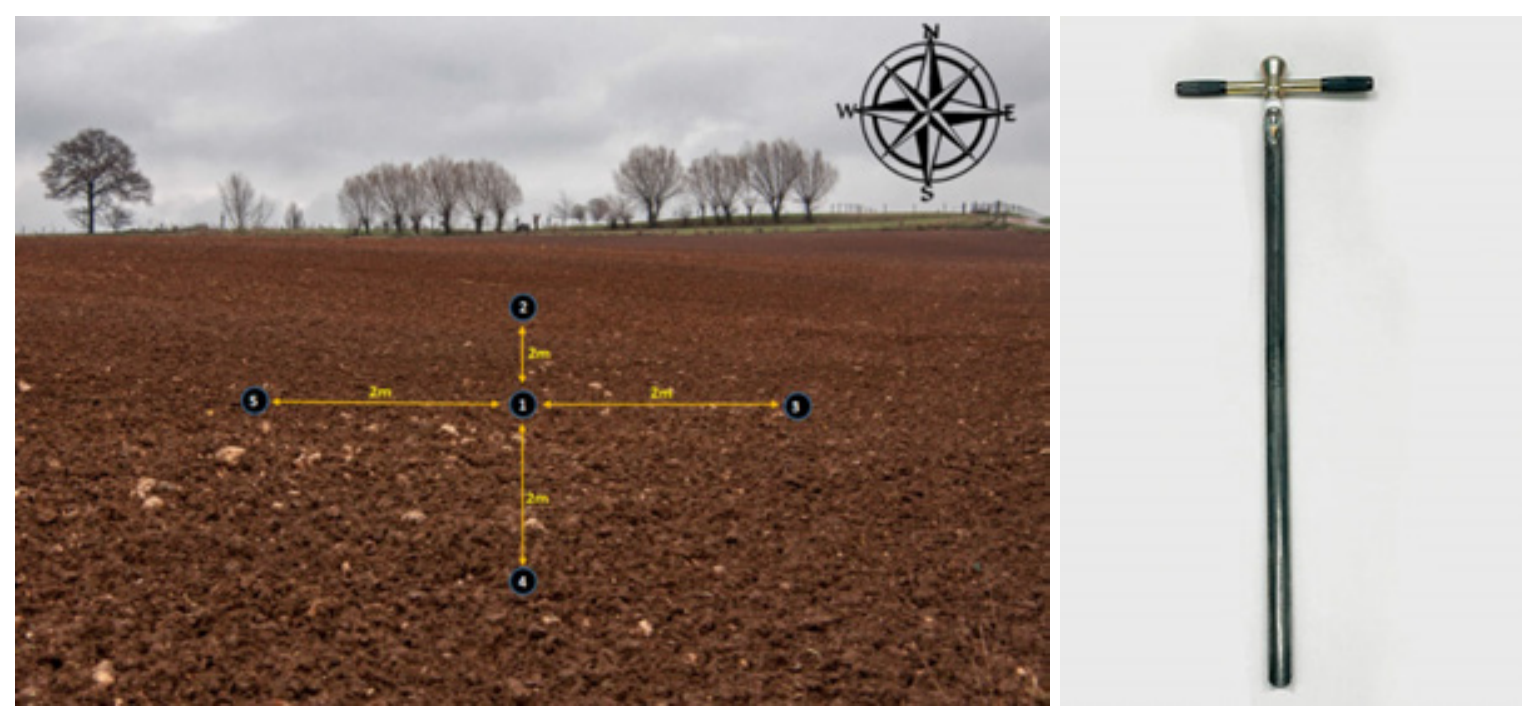

Figuur B1.1 Bemonsteringsmethode.

Figuur B1.2 Steekguts.

\section{Achtergrond}

Wat te meten?

De voorraad koolstof in de bodem. Hiervoor is het koolstofgehalte (in $\mathrm{g} / \mathrm{g}$ ) en de bulkdichtheid (in $\mathrm{g} / \mathrm{cm} 3$ ) van belang. De voorraad koolstof wordt vastgesteld voor de lagen 0-30 cm en 30-100 cm.

Hoe te meten?

Van grond, gezeefd met een $2 \mathrm{~mm}$ zeef, wordt op het lab het koolstofgehalte bepaald in $\mathrm{g} / \mathrm{g}$ droge grond. Plantendelen groter dan $2 \mathrm{~mm}$ worden daarin niet meegenomen. Dat betekent ook dat een strooisellaag of een wortelmat niet bemonsterd wordt. De bulkdichtheid wordt berekend door bekende volumes grond te bemonsteren en die op het lab tot $105^{\circ} \mathrm{C}$ te drogen en daarna te wegen. 


\section{De bemonsteringsdiepte}

Het maaiveld vormt de bovenkant van de bemonstering. Een eventuele strooisellaag telt niet mee, ook de bovengrondse grasmat wordt niet meegenomen. De Landelijke Steekproef Kaarteenheden (LSK) van de jaren 1994-2001 gebruikte de onderscheiden horizonten als te onderscheiden bemonsteringslagen. Omdat in 2018 niet elke veldmedewerker horizonten kan onderscheiden en omdat de koolstofvoorraden van de lagen 0-30 cm en 30-100 cm doelvariabelen zijn, worden geen horizonten bemonsterd, maar worden de lagen van 0 tot $30 \mathrm{~cm}$ en van 30 tot $100 \mathrm{~cm}$ bemonsterd. Kuikman et al. (2003) berekenden voor de locaties van de LSK de koolstofvoorraad in de laag van 0 tot $30 \mathrm{~cm}$ door gewogen gemiddelden te nemen uit de voorraden voor de horizonten die geheel of gedeeltelijk tussen 0 en $30 \mathrm{~cm}$ lagen. Hierdoor is het mogelijk een vergelijking te maken tussen de voorraden in circa 1998 en 2018.

\section{Laagopbouw en locatie}

De laagopbouw van de bodem en de omgeving worden gefotografeerd. Van elke afgestreken steek met de guts (bv. 0-30 en 30-100 cm) op het middelste punt, wordt een foto gemaakt van de laagopbouw. Om de juiste diepten later te kunnen achterhalen, wordt er een meetlat van een meter op de corresponderende diepte mee gefotografeerd. Tevens wordt een overzichtsfoto van de bemonsteringsplek gemaakt. De foto's worden altijd gemaakt met op een bord het nummer van het monster, evenals een bord met het locatienummer.

\section{Administratie van bemonstering}

Veldmedewerkers vullen op elke locatie een checklist in. Deze bemonsteringslijst waarborgt dat alle stappen voor bemonstering doorlopen worden en alle gewenste informatie genoteerd staat. Tevens biedt de lijst de mogelijkheid om overige informatie te noteren, bijvoorbeeld aanvullende contactgegevens van de landeigenaar etc.

\section{Bewerking}

De mengmonsters die zijn samengesteld uit grondmonsters die met de afgestreken guts zijn verzameld, representeren een zeker volume grond. De mengmonsters worden na monstername zo snel mogelijk in een afgesloten plastic zak gedaan en op het lab gewogen. Daarna kan de volledige inhoud met de zak op een ondiep groot metalen blad worden uitgespreid om eerst gedurende 1 à 2 uur bij $40^{\circ} \mathrm{C}$ te drogen. Na voorzichtige verwijdering van het zo schoon mogelijke zakmateriaal wordt vervolgens 24 uur bij $105^{\circ} \mathrm{C}$ gedroogd. Daarna wordt weer gewogen. Er gaat bij het verwijderen van de zak na eerst te drogen bij $40^{\circ} \mathrm{C}$ zo weinig mogelijk grond en vocht verloren. Het vochtgehalte van de grond wordt vervolgens berekend door het verschil in massa tussen begin- (gecorrigeerd voor de massa van de plastic zak) en eindmassa te delen door het volume. Het vochtgehalte is nodig om te bepalen onder welke omstandigheden (droog of nat) monsters zijn genomen. Het geeft ook inzicht in de waarde van een eventuele meting van de indringingsweerstand met de penetrologger. De dichtheid wordt berekend door de massa van de droge grond te delen door het volume. Dit is ook de dichtheid die men normaal verkrijgt door een ringmonster bij $105^{\circ} \mathrm{C}$ te drogen. Vervolgens wordt het grondmonster gezeefd en eventueel gemalen. Daarna wordt een submonster genomen en gewogen voor de C-analyse etc.

\section{Restvocht}

- 6 uur drogen bij $105^{\circ} \mathrm{C}$

Org. stof-gloeiverlies

- een hoeveelheid bij $105^{\circ} \mathrm{C}$ gedroogd monster wordt gedurende 3 uur gegloeid bij $550^{\circ} \mathrm{C}$

Org. stof-elementair

- verbranding van een bepaalde hoeveelheid monster in een zuurstofstroom bij $600^{\circ} \mathrm{C}$

- meting van de ontstane $\mathrm{CO}_{2}$ in een infraroodcel

C-totaal-elementair

- verbranden in $\mathrm{O}_{2}$ bij $11500^{\circ} \mathrm{C}$

- meting van ontstane $\mathrm{CO}_{2}$ in een infraroodcel

N-totaal-elementair

- verbranden in $\mathrm{O}_{2}$ bij $10500^{\circ} \mathrm{C}$

- reduceren

- meting van ontstane $\mathrm{NO}_{2}$ in een TC-cel Omrekening van lutum naar droge stof niveau OS- $(0,07 * A) / 10$ 
Waarin:

$\mathrm{OS}=$ gegeven uit gloeiverlies

$A=$ Lutum*(1000/(1000-restvocht)

\section{Werkwijze bemonstering CC-NL}

\section{Toestemming}

Het is noodzakelijk om te allen tijde de grondgebruiker op te zoeken en toestemming te vragen voor grondbemonstering. Als de grondgebruiker/eigenaar toestemming voor bemonstering weigert, dan vervalt het meetpunt. Mocht er worden aangegeven dat er bij voorkeur op een ander tijdstip wordt bemonsterd, bijvoorbeeld door werkzaamheden, dan wordt een vervolgafspraak gemaakt (mits dit past binnen de meetcampagne). Als er niemand is om toestemming te vragen, dan wordt telefonisch contact gezocht of op een ander moment teruggekomen. Zonder toestemming wordt een perceel niet betreden. Bij grote beheerders van natuurterreinen zoals SBB en Natuurmonumenten wordt centraal toestemming en/of een vergunning gevraagd.

\section{Locatie \& plot}

De coördinaten van de te bezoeken locaties zijn opgeslagen in een bestand. Bij elke locatie staat een locatienummer. Dit nummer wordt ook vermeld op de monsterzak en in de bemonsteringslijst. Met behulp van de gps wordt genavigeerd naar de locatie. Indien de locatie bebouwd of verhard (wegen, erven) is, vervalt het punt. Ook punten in sloten en andere watergangen vervallen. Blijkt het punt dicht bij een sloot of weg te liggen, dan wordt dit punt bemonsterd, maar levert dit mogelijk gevaarlijke situaties op in verband met verkeer, kabels, leidingen etc., dan vervalt het punt. Het punt mag (binnen de onnauwkeurigheid van de locatiemeetapparatuur) maximaal $5 \mathrm{~m}$ verlegd worden.

Vanuit het midden bepalen we de overige steekpunten door met een kompas in noordelijke, oostelijke, zuidelijke en westelijke richting op $2 \mathrm{~m}$ afstand een punt te markeren (zie figuur B1.3).

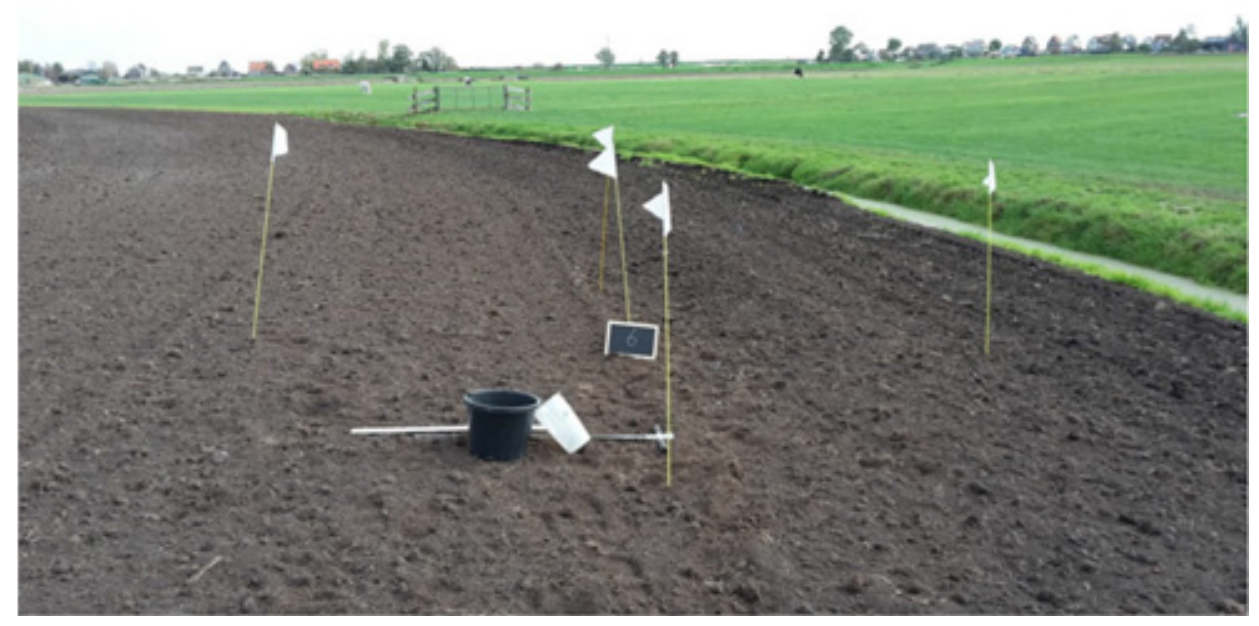

Figuur B1.3 Voorbeeld van plot.

Hoe om te gaan met geploegd land?

Veel akkergronden zijn in het najaar bewerkt, waardoor het maaiveld ongelijk is. Bij geploegde akkers is het de bedoeling om te bemonsteren op de flank van een 'rug' om zo de variatie in de metingen als gevolg van ploegen te verkleinen (zie figuur B1.4). Er wordt dus niet bemonsterd op het hoogste deel van de rug, of tussen twee rijen in het laagste deel. 


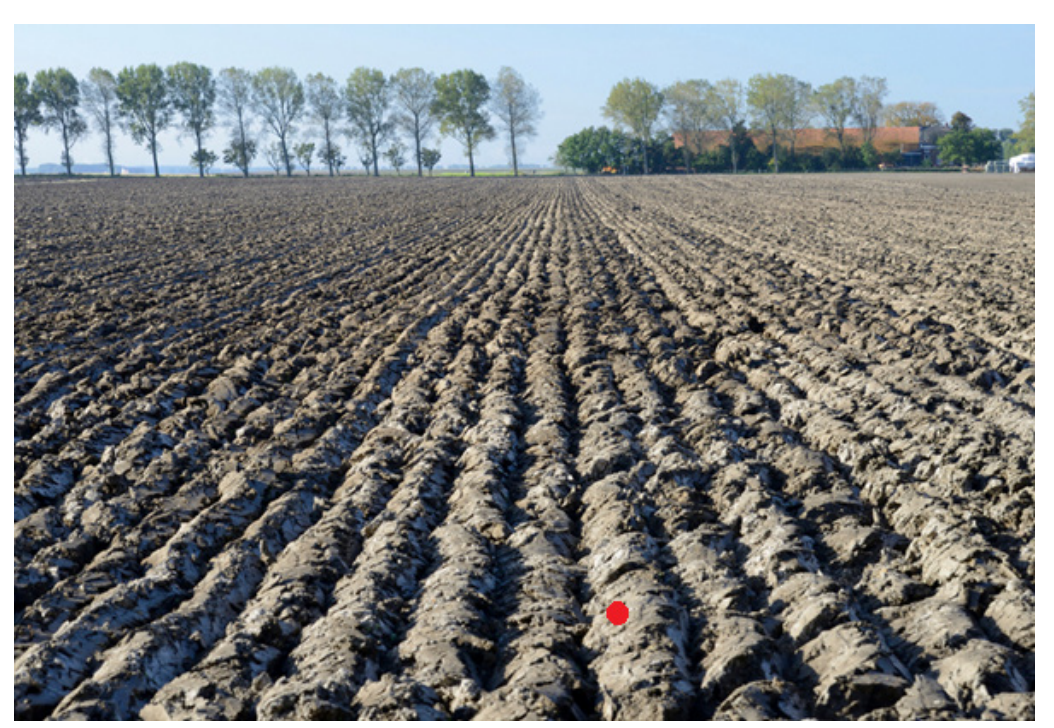

Figuur B1.4 Omgaan met geploegd land.

\section{Bemonstering}

Voor elke locatie zijn twee grondmonsterzakken nodig: één voor de diepte $0-30 \mathrm{~cm}$ en één voor de diepte $30-100 \mathrm{~cm}$. Een zakkenhouder of emmer is handig om de zakken in te zetten, zodat snel het grondmonster in de zak kan worden gedaan. Een andere optie is om het grondmonster in een emmer op te vangen en vervolgens in de zakken te verdelen.

De monsterzakken worden genummerd met het nummer van de locatie. Verder wordt op de zak de bemonsteringsdiepte vermeld: $0-30 \mathrm{~cm}$ of $30-100 \mathrm{~cm}$. Indien de bemonsterde diepte van de tweede laag minder is dan $100 \mathrm{~cm}$, wordt dat hier ook aangegeven. Het volledige profiel van $0-100 \mathrm{~cm}$ wordt, waar mogelijk, steeds bemonsterd. Als de grond erg nat is, wordt een extra monsterzak gebruikt i.v.m. het risico op scheuren. Zodra alle grondmonsters genomen zijn, worden de monsterzakken dichtgemaakt met een nietje.

\section{Gebruik steekguts}

De steekguts heeft een guts met een doorsnede van $3 \mathrm{~cm}$ met een scherpe snijrand. De steekguts kan met een hamer de grond in worden geslagen. De guts heeft een slagkop waarop met een terugslagvrije hamer geslagen kan worden. Waar mogelijk wordt de steekguts in de grond geduwd. Als duwen niet meer lukt, wordt de steekguts verder de grond in geslagen (zie figuur B1.5).

De steekguts wordt in de grond gebracht tot een diepte waarop het inbrengen te zwaar wordt. Dit verschilt sterk tussen bijvoorbeeld een vochtige veengrond of drogere kleigrond. De guts wordt uit de grond getrokken nadat deze een aantal keer is gedraaid (zo blijft de grond beter zitten en komt de guts soepeler omhoog). Als het erin slaan heel moeizaam gaat is het raadzaam om in etappes van 10 à $20 \mathrm{~cm}$ te bemonsteren.

Als de guts uit de grond omhoog is gehaald, wordt de grond vlak afgeschraapt met een spatel. Het is belangrijk dat dit zo vlak mogelijk gebeurt, omdat er gerekend wordt met volumes. Het is hierbij raadzaam om het grondmonster in de guts van onderaf naar boven toe af te vlakken om te voorkomen dat er per ongeluk grond uit de guts valt (zie figuur B1.6). 


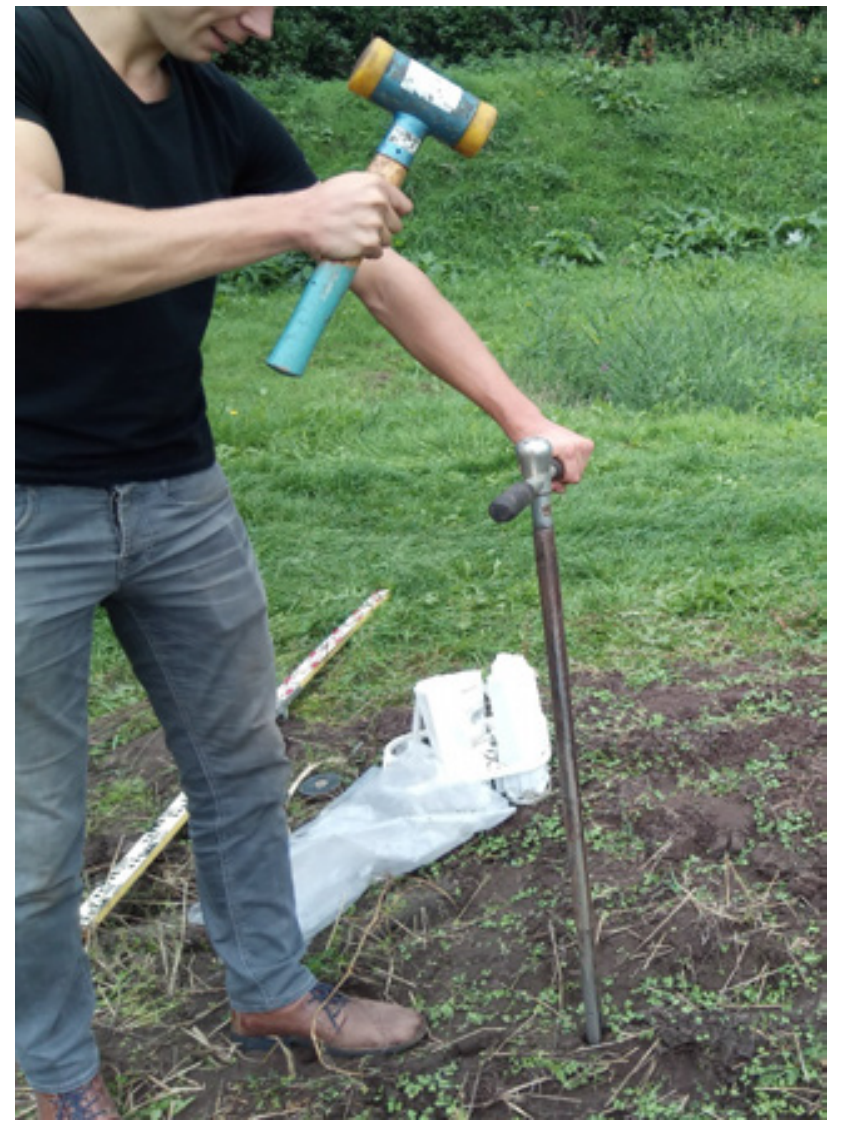

Figuur B1.5 Gebruik van steekguts.

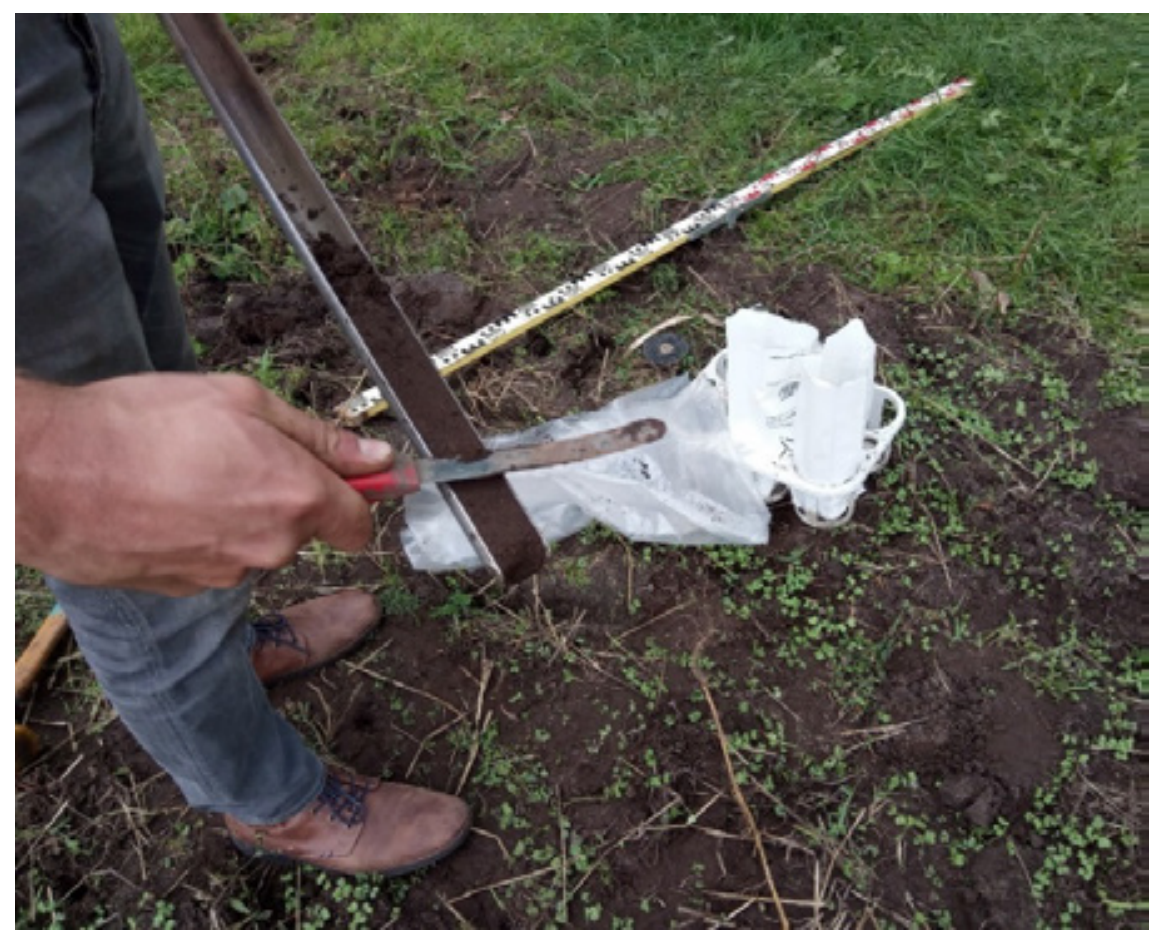

Figuur B1.6 Afvlakken van het grondmonster in de guts.

De eerste steek zal in veel gevallen relatief gemakkelijk gaan tot een zekere diepte. Het is belangrijk steeds te onthouden tot hoe diep de steek is genomen. Dit kan afgelezen worden door de $10 \mathrm{~cm}$ streepjes op de zijkant van de guts te tellen, zoals te zien is op figuur B1.7. Het is daarbij handig om steeds steken van $10 \mathrm{~cm}$ of een veelvoud hiervan te nemen. 


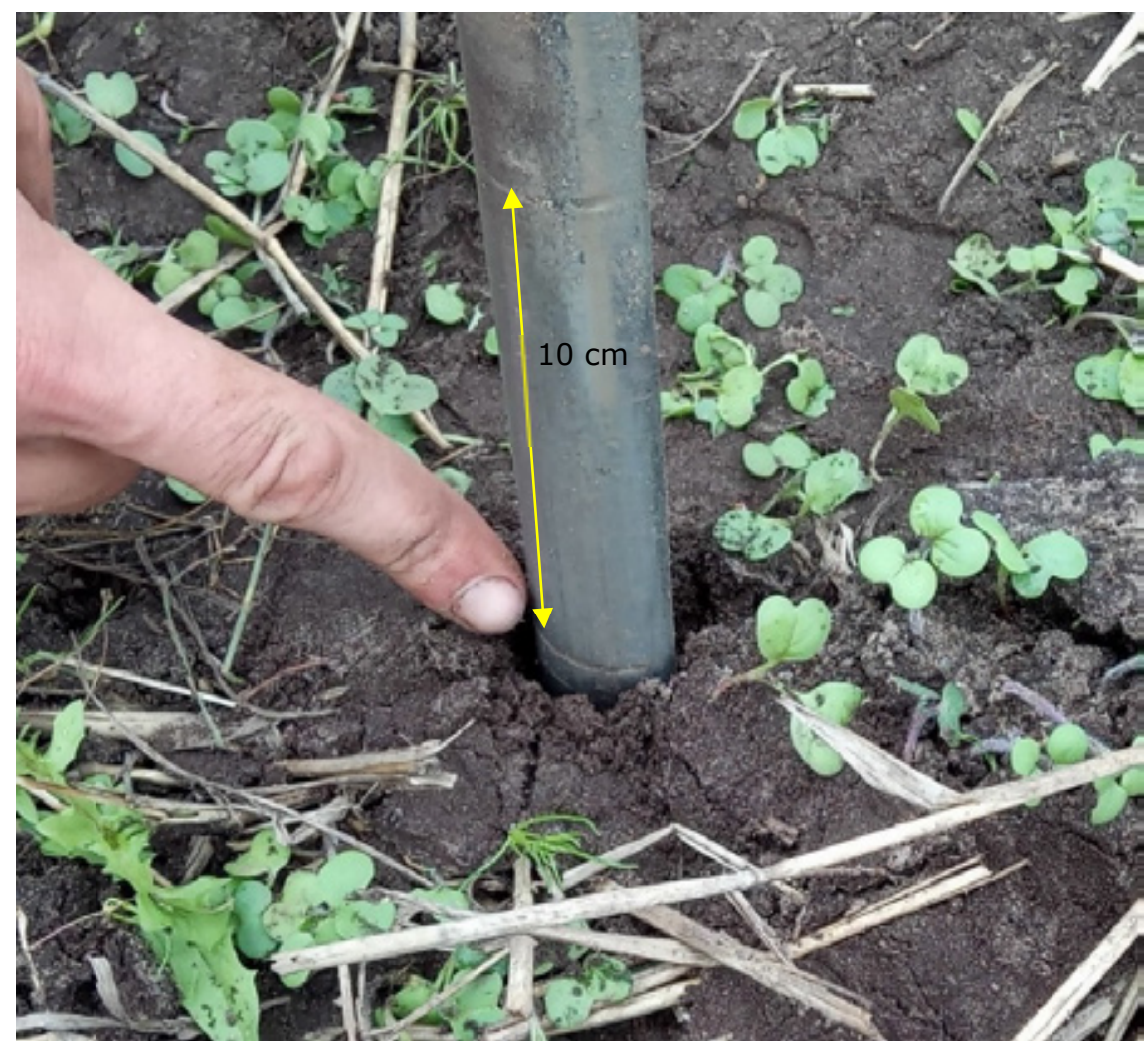

Figuur B1.7 Decimeterstrepen op steekguts.

$\mathrm{Na}$ het afvlakken, wordt de monsterzak gevuld met de grond uit de guts. Vervolgens wordt de volgende steek gedaan. Steeds wordt ervoor gezorgd dat er zo min mogelijk grond in het gat valt. Bij de volgende ste(e)k(en) zal bij het ophalen blijken dat er meer grond in zit dan de diepte tot waar bemonsterd is. Dit is losse grond die met het uitdraaien op de te bemonsteren grond is gevallen. Deze grond moet verwijderd worden (zie figuur B1.8). Het is dus belangrijk van tevoren te bedenken hoe veel grond er in de guts verwacht wordt. Bijvoorbeeld: bij de vorige steek is tot $50 \mathrm{~cm}$ bemonsterd en hierna tot $70 \mathrm{~cm}$. De verwachting is dat er nu $20 \mathrm{~cm}$ grond in de guts zit. Als er vervolgens $25 \mathrm{~cm}$ in zit, is hiervan $5 \mathrm{~cm}$ ingevallen. Deze grond is goed te herkennen aan een lossere structuur of kleurverschil.

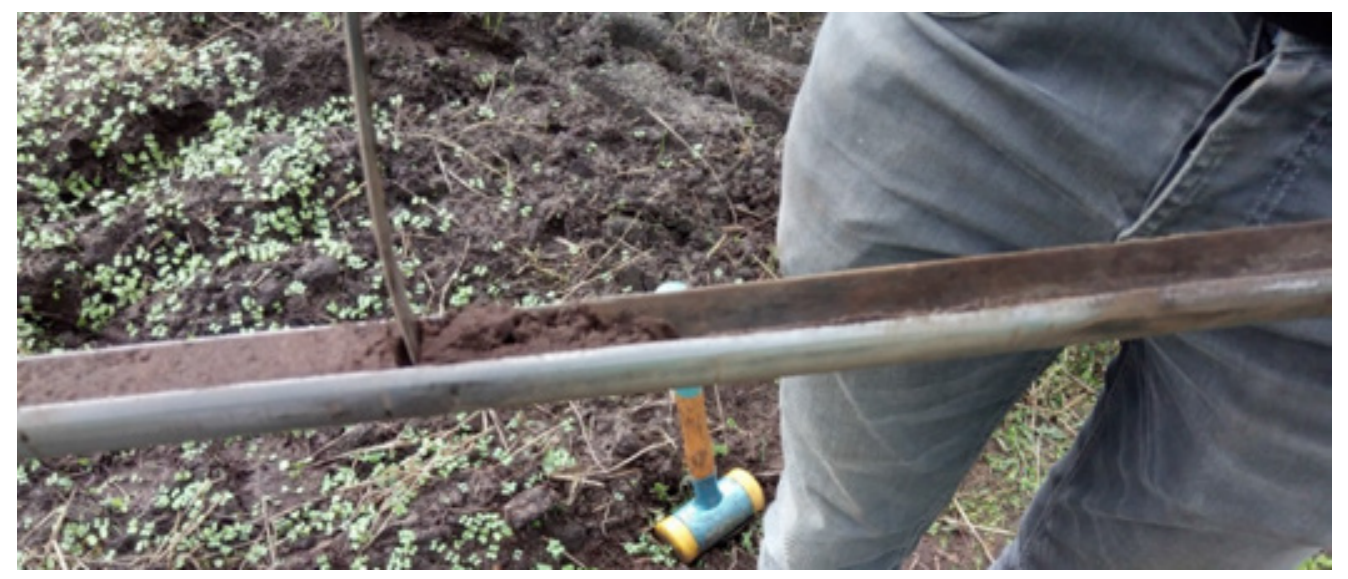

Figuur B1.8 Verwijderen van ingevallen grond.

Als de beoogde $100 \mathrm{~cm}$ niet wordt gehaald om wat voor reden dan ook (bijvoorbeeld een grindlaag, natte grond, droge zandgrond etc.) wordt de maximale diepte die bemonsterd is als einddiepte genoteerd op de monsterzak en het formulier, evenals de reden. Het is van belang bij alle vijf steken per locatie tot dezelfde diepte te bemonsteren. De middelste steek is daarvoor leidend. Als hier tot $70 \mathrm{~cm}$ is bemonsterd, worden de overige vier steken ook tot $70 \mathrm{~cm}$ genomen. 
Het kan gebeuren dat (droge) grond niet overal goed in de guts blijft zitten. Indien er minder dan $5-10 \%$ grond uitgevallen is, mag dit voordat de guts vlak wordt gestreken, 'gerepareerd' worden met grond totdat de guts weer vlak met de gutsrand vol zit. Het is hierbij belangrijk de grond niet hard aan te duwen, waardoor de grond verdicht wordt. Als er te veel grond ontbreekt, moet er een nieuwe steek worden genomen. Hiernaast kan het voorkomen dat er grond uit de punt van de guts valt bij het omhooghalen. Deze grond ligt nu onder in het boorgat. Door bij de volgende steek iets dieper te steken, kan deze grond alsnog meegenomen worden.

Tevens kan het gebeuren dat de guts in een scheur of andere holte wordt gestoken. Van zo'n laag is het lastig om een goed monster te nemen. Als de guts daardoor te weinig grond bevat, dient er een nieuwe steek te worden uitgevoerd. Bevat een steek dan nog steeds een deel lucht, dan nemen we aan dat de dichtheid van die grond door krimp tijdelijk is veranderd en dat de dichtheid berekend kan worden met het gemiste volume. Het is dan belangrijk dit met foto's goed vast te leggen. In gevallen dat er incidenteel bij een monsterplek niet verder kan worden gestoken, moet er vlak naast in de bemonsteringscirkel een nieuwe steek worden genomen totdat de diepte van $100 \mathrm{~cm}$ is bereikt.

\section{Fotograferen bodemmonster}

Om naderhand de profielopbouw te kunnen bekijken, is het van belang deze vast te leggen op een foto. Van elke afgestreken steek met de guts (bv. 0-30, 30-40 en 40-100 cm) bij het middelste punt van elke plek wordt een foto van de laagopbouw genomen (zie figuur B1.9). Om de juiste diepte later te kunnen achterhalen, moet er een meetlat van een meter op de juiste diepte mee gefotografeerd worden, evenals een bord met het locatienummer. De meetlat ligt altijd zo dat de hoogste waarde aan de onderkant van de guts ligt.

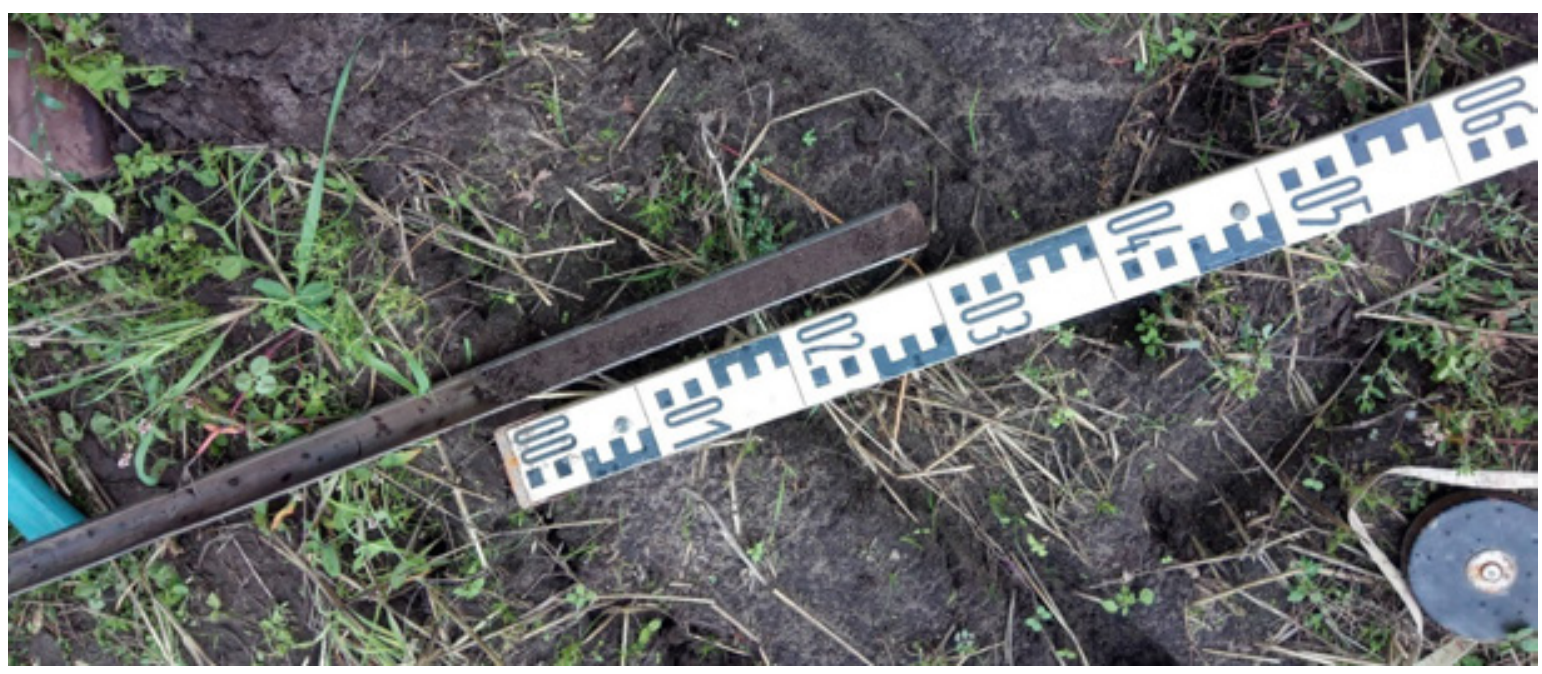

Figuur B1.9 Voorbeeldfoto van de bovenste $30 \mathrm{~cm}$.

\section{Gebruik penetrologger}

Op alle locaties gebruiken we de penetrologger om metingen te doen van de indringingsweerstand. De penetrologger bevat een plan voor het meten op een aantal locaties, plots genoemd. Bij elke plot worden vijf metingen gedaan vlak bij de locaties waar we de grondmonsters zijn genomen (max. $30 \mathrm{~cm}$ ervandaan). Naast het scherm van de logger zitten witte druktoetsen (zie figuur B1.10). De logger gaat aan met de knop bovenaan; met de "einde" keuzeknop gaat de logger uit. Na enkele minuten niet gebruiken gaat de logger vanzelf uit.

Om een meting te starten, moet de knop "meten" ingedrukt worden. Kies vervolgens een project door met de pijltjestoetsen het juiste "Proj" te kiezen en dan op "ok" te drukken. Voor dit onderzoek heet het project "CC-NL". 


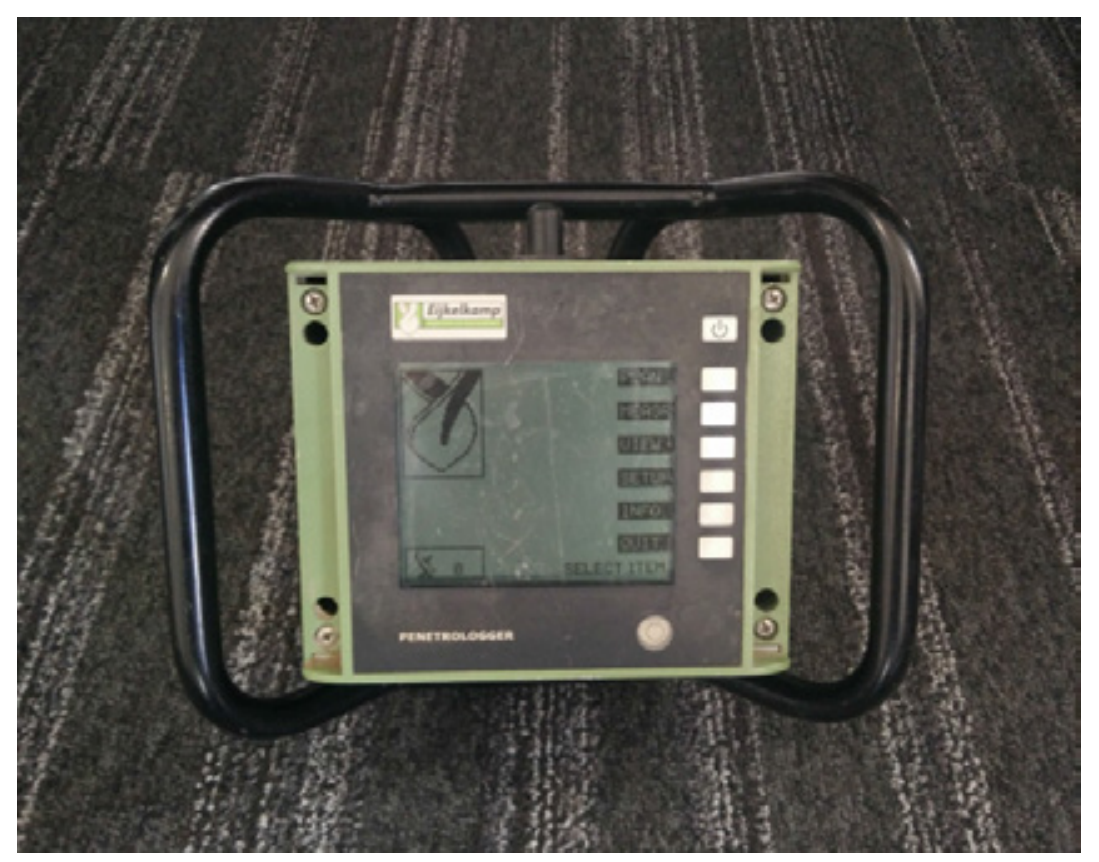

Figuur B1.10 Het scherm van de logger bevat toetsen voor de bediening.

Vervolgens verschijnt een scherm, zoals te zien is in figuur B1.11. Door op "start" te drukken start de meting. De conus van de pen moet dan al boven het gat van de referentieplaat staan, met de punt tegen het maaiveld aan. Daarna kan de pen met conus in het gat van de diepte-referentieplaat gedrukt worden. Op het scherm verschijnt een grafiek die de meting met de diepte weergeeft. Aan de linkerkant van het scherm verschijnt een balk met een snelheidsindicator die aangeeft of er te langzaam (balk bovenaan) of te snel (balk onderaan) in de grond wordt geschoven. Een piepgeluid geeft aan dat er buiten het vereiste snelheidsbereik wordt gemeten. Sluit de meting dan af zonder te bewaren en herhaal de meting (niet in hetzelfde gat). Wanneer de weerstand te groot wordt (6 MPa), lukt het bijna niet meer om de pen verder de grond te drukken. Stop dan met drukken. Het apparaat zal dan ook piepen, omdat er te langzaam gemeten wordt. Deze meting kan worden opgeslagen. Als de meting is afgerond verschijnt vanzelf de vraag "bewaren?". Klik op "ja". Tijdens de metingen wordt geen gebruikgemaakt van een vochtmeter (staat uit in de "set"), maar wel gps (staat aan in de "set"). Daarom stelt de logger eerst de vraag "gps-meting bewaren?". Druk dan ook "ja" in. 


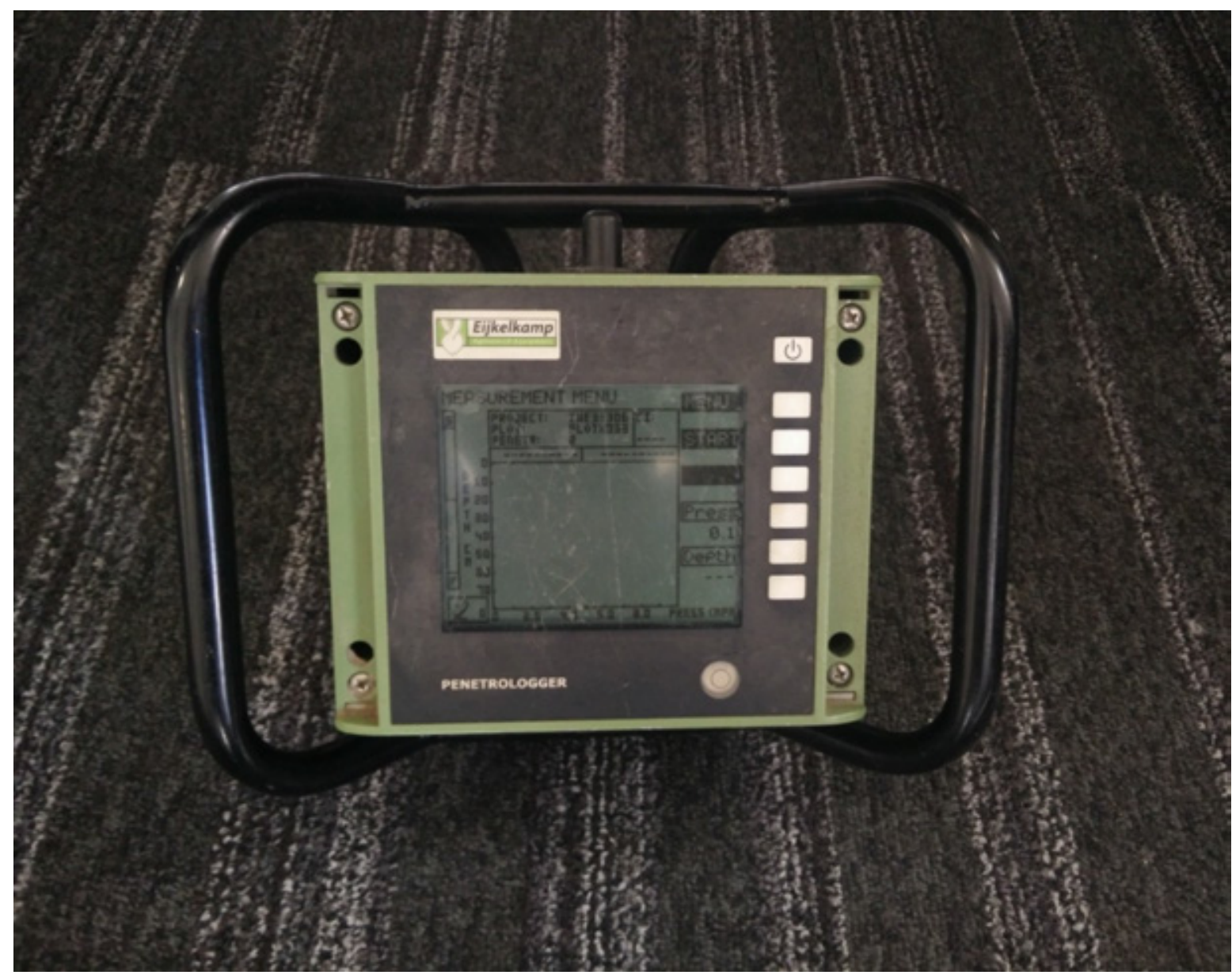

Figuur B1.11 Het meetscherm tekent een grafiek tijdens het meten.

Het scherm van de penetrologger kan bij het uitpakken wat condens geven. Laat de penetrologger dan een tijdje acclimatiseren, zodat de condens verdwijnt. Voor het starten van een meting moet de referentieplaat zo horizontaal mogelijk op de bodem geplaatst worden aan de hand van de hierop aanwezige waterpas (zie figuur B1.12).

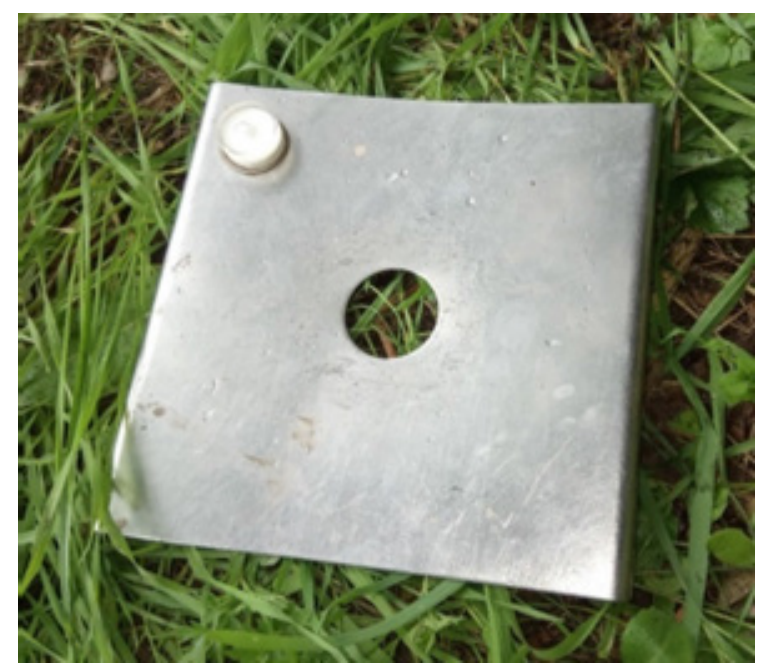

Figuur B1.12 Diepte-referentieplaat.

Daarna wordt de pen met aan het eind een conus in het midden van het gat in de diepte-referentieplaat gezet, zoals te zien is in figuur B1.13. Druk vervolgens op start en begin geleidelijk te drukken. Het is belangrijk om evenwichtig druk uit te oefenen, zodat de pen zo verticaal mogelijk in de grond zakt 
(max. afwijking $3.5^{\circ}$ ). Verder is het van belang dat de snelheid van indrukken gelijkmatig is en zo veel mogelijk een snelheid van $2 \mathrm{~cm} / \mathrm{sec}$ benadert, dit is te zien op het scherm van de logger.

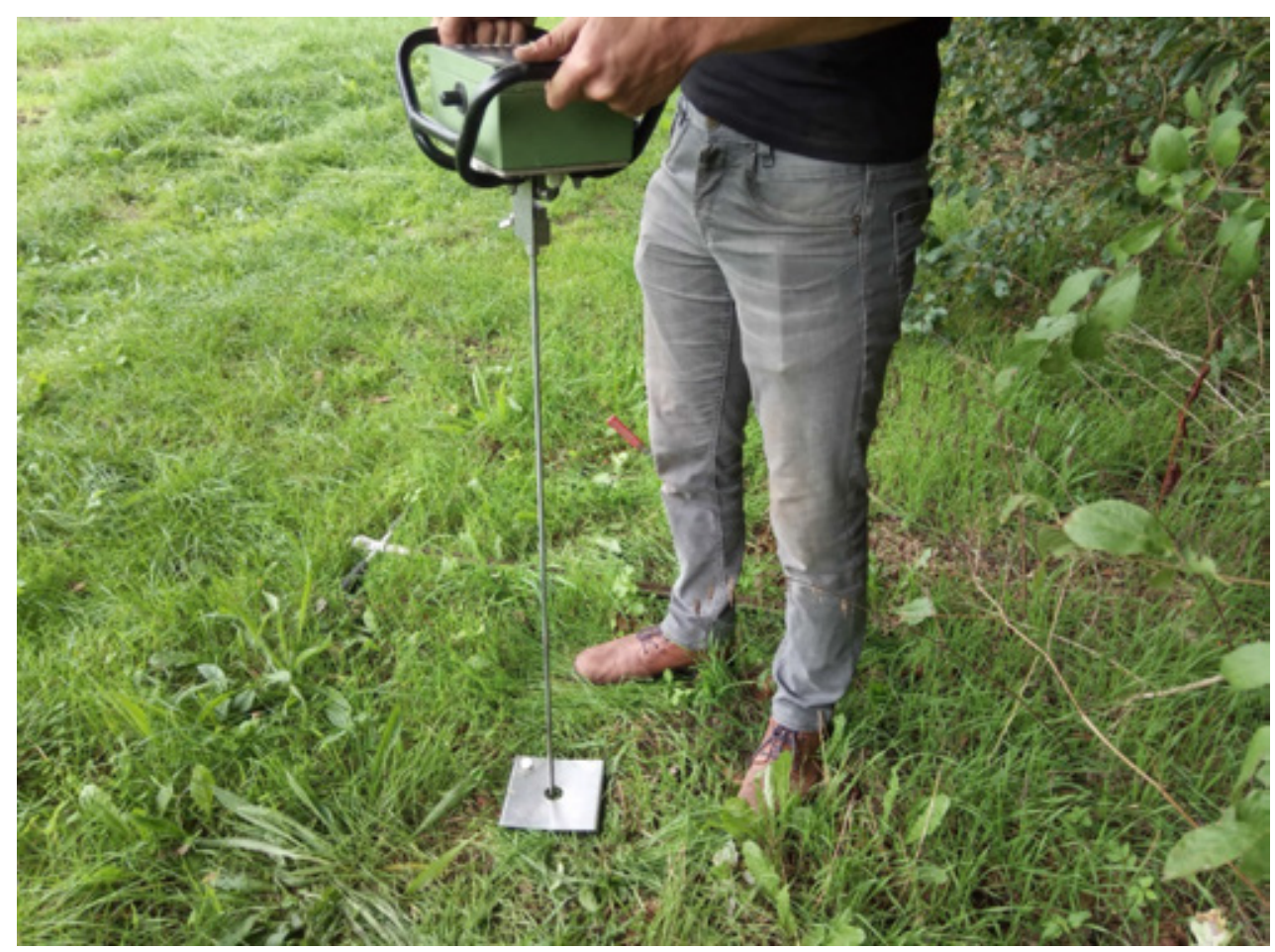

Figuur B1.13 Gebruik Penetrologger.

De weerstand kan te groot zijn om de conus in de grond te drukken. In zo'n geval is de indringingsweerstand van de grond erg hoog. In dat geval wordt de meting tot de bereikte meetdiepte bewaard. Er wordt niet gewrikt of gerukt om de conus de grond in te krijgen; lichaamsgewicht is de maximale druk die uitgeoefend mag worden, maar daardoor is de kans groot op een kromme stang. Daarom wordt op tijd gestopt als de uitslag richting 6 MPa gaat.

De weerstand kan ook heel laag zijn, bijvoorbeeld in veengrond. Dan wordt toch een meting gedaan, waarbij ervoor gezorgd wordt dat de snelheid van indrukken in de buurt van $2 \mathrm{~cm} / \mathrm{sec}$ blijft. De lage gemeten indringingsweerstand is ook een valide meting. Tot slot wordt gecheckt of alle metingen gedaan en opgeslagen zijn en wordt de meting afgesloten. 


\section{Vastlegging}

Tot slot wordt gecontroleerd of de bemonsteringslijst correct is ingevuld, zoals te zien is in figuur B1.14 en wordt de plek netjes achtergelaten (gaten dichtmaken). De bodemmonsters worden elke dag door een koerier opgehaald.

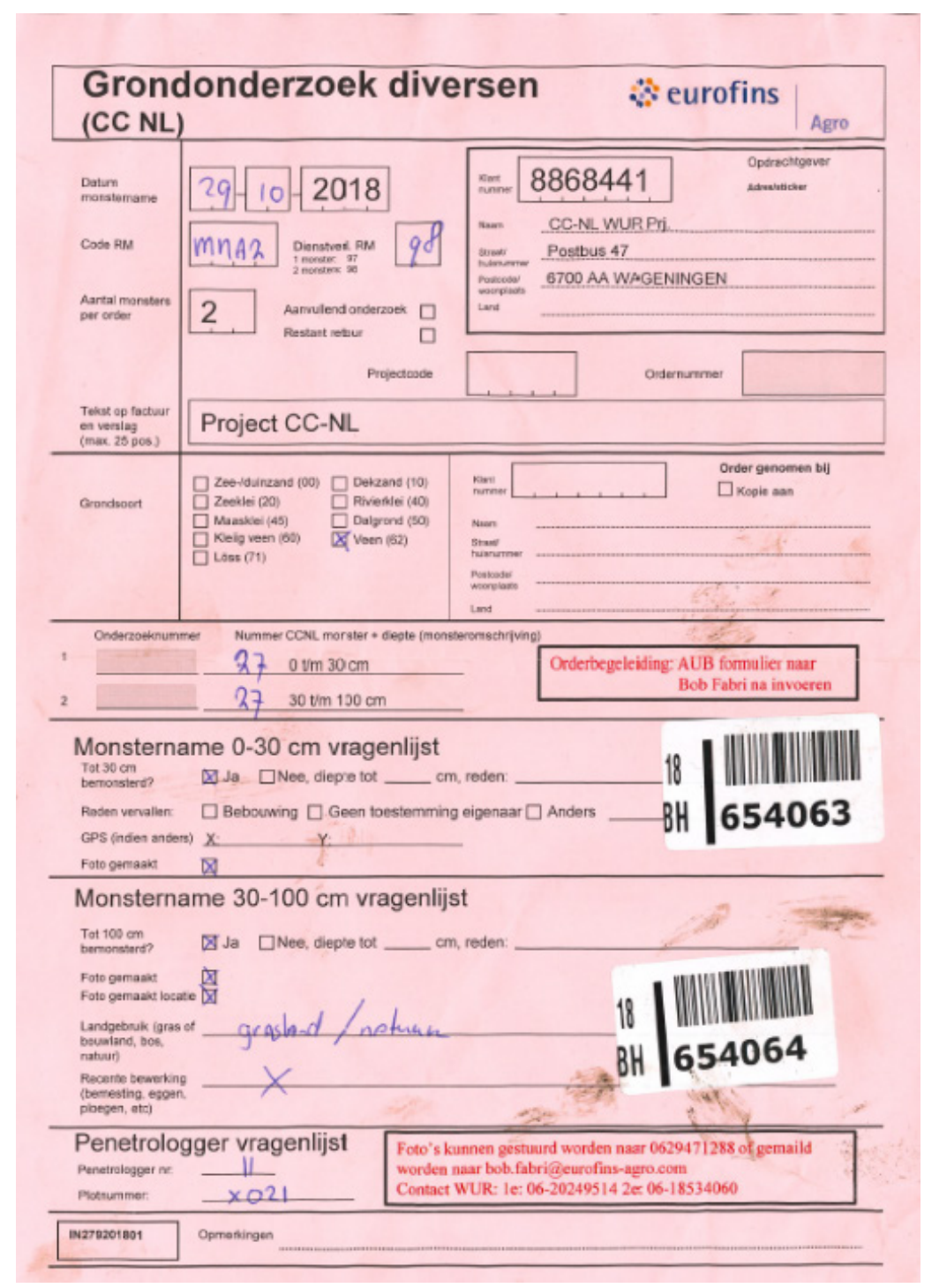

Figuur B1.14 Bemonsteringslijst.

\section{Benodigd bemonsteringsgereedschap}

- Veldcomputer of smartphone

- Steekguts met ramkop ( $100 \mathrm{~cm}$ lengte $\& 3 \mathrm{~cm}$ doorsnee)

- Terugslagvrije hamer

- Spatel

- Nummerbord en krijt

- Meetlat van $1 \mathrm{~m}$ met $\mathrm{cm}$-verdeling

- Kompas

- Piketstokken

- Emmer 10 I

- Nietapparaat

- Monsterzakken met 2L- en 4L-volume

- Fotocamera (optioneel)

- Penetrologger (incl. conus $1 \mathrm{~cm}^{2}$, drukstangen, diepte-referentieplaat)

- Bemonsteringslijst \& notitiematerialen

- Informatiebrief 


\section{Stappenplan bemonstering CC-NL}

1. Zoek het adres op en vraag toestemming aan de landeigenaar. Overhandig hierbij de informatiebrief.

2. Stel door middel van gps het midden van de monsterlocatie vast en markeer deze plek met een piketstok.

3. Stel met behulp van een kompas het noorden vast.

4. Markeer op $2 \mathrm{~m}$ afstand van het midden naar het noorden een steekpunt met een piketstok en doe voor de overige windrichtingen hetzelfde.

5. Noteer het nummer van de monsterlocatie op een schrijfbord.

6. Zet de monsterzakken met daarop het nummer van de locatie en de twee monsterdieptes 0-30 cm en 30-100 cm open in een houder of emmer.

7. Neem met de steekguts een volumemonster van 0-30 cm bij het middelste punt. Strijk hierbij de guts vlak af.

8. Leg de meetlat en een bord met het nummer van de locatie langs het monster en maak hier een duidelijke foto van.

9. Leeg de inhoud van de guts in de juiste monsterzak.

10. Neem met de steekguts een monster van $30-100 \mathrm{~cm}$ bij het middelste punt. Strijk hierbij de guts vlak af (wellicht zijn er meerdere steken nodig om te bemonsteren).

11. Leg de meetlat en een bord met het nummer van de locatie langs het monster en maak hier een duidelijke foto van (indien in meerdere steken bemonsterd, maak van elke steek een foto). Leeg vervolgens de inhoud van de guts in de juiste monsterzak.

12. Maak een duidelijke foto van het bord met het nummer en de locatie.

13. Volg voor de overige vier steken dezelfde werkwijze als bij het middelste punt. Let op! Bij de overige vier steken hoeven geen foto's gemaakt te worden.

14. Niet de monsterzakken dicht.

15. Stel de penetrologger in en doe op max. $30 \mathrm{~cm}$ van de 5 steekplekken een weerstandmeting tot zover dit mogelijk is.

16. Vink in de bemonsteringslijst alle uitgevoerde stappen aan.

17. Noteer in de bemonsteringslijst de werkelijke bemonsteringsdiepten.

18. Noteer in de bemonsteringslijst eventuele bijzonderheden (reden afwijkende bemonsteringsdiepte of overige informatie).

19. Maak iedere dag een afspraak om de monsters op te laten halen door een koerier. 


\section{Bijlage 2 Punten per deelgebied}

\section{Indeling in minerale en veen- en moerige gronden op basis van de bodemkaart}

Tabel 2 heeft betrekking op het deel van Nederland dat volgens de Bodemkaart van Nederland, schaal $1: 50.000$ (dit is de bodemkaart die is gebruikt voor de bepaling van het LSK meetnet), uitsluitend uit minerale gronden bestaat. Verder zijn in paragraaf 3.3 deelgebieden onderscheiden die volgens de Bodemkaart van Nederland, schaal $1: 50.000$, geheel of gedeeltelijk uit veen- en moerige gronden bestaan, waarbij ook onderscheid is gemaakt naar de diepte waarbinnen veen en moerig materiaal voorkomt.

Dit levert de volgende vijf deelgebieden op:

1. strata met kaarteenheden van veen- en moerige gronden, waarbij moerig materiaal ondieper dan $30 \mathrm{~cm}$ kan voorkomen;

2. strata met kaarteenheden van veen- en moerige gronden, waarbij moerig materiaal dieper dan $30 \mathrm{~cm}$ voorkomt;

3. strata met onder andere kaarteenheden van veen- en moerige gronden, waarbij moerig materiaal ondieper dan $30 \mathrm{~cm}$ kan voorkomen;

4. strata met onder andere kaarteenheden van veen- en moerige gronden, waarbij moerig materiaal dieper dan $30 \mathrm{~cm}$ voorkomt;

5. strata met kaarteenheden van minerale gronden.

Tabel 16 geeft aan welke strata uit de LSK (Finke et al., 2001) tot welk van de vijf deelgebieden behoren. 
Tabel B2.1 Onderscheid naar minerale en veen- en moerige gronden. Tussen haakjes: strata met één of geen waarneming.

\begin{tabular}{|c|c|c|c|c|}
\hline \multicolumn{2}{|c|}{$\begin{array}{l}\text { Strata met kaarteenheden van veen- en } \\
\text { moerige gronden }\end{array}$} & \multicolumn{2}{|c|}{$\begin{array}{l}\text { Strata met onder andere kaarteenheden } \\
\text { van veen- en moerige gronden }\end{array}$} & \multirow{4}{*}{$\begin{array}{l}\text { Strata met } \\
\text { kaarteenheden van } \\
\text { minerale gronden }\end{array}$} \\
\hline moerig materiaal & moerig materiaal & moerig materiaal & moerig materiaal & \\
\hline kan ondieper dan & komt dieper dan & kan ondieper dan & komt dieper dan & \\
\hline $30 \mathrm{~cm}$ voorkomen & $30 \mathrm{~cm}$ voor & $30 \mathrm{~cm}$ voorkomen & $30 \mathrm{~cm}$ voor & \\
\hline 1501 & 2007 & 1505 & 1504 & 1503 \\
\hline 1502 & & 1605 & 1608 & 1801 \\
\hline 1601 & & 1606 & 1704 & 1901 \\
\hline 1602 & & 1607 & 1705 & 1902 \\
\hline 1603 & & 1609 & 1802 & 1904 \\
\hline 1604 & & 1703 & 1804 & 1905 \\
\hline 1701 & & 1706 & 1805 & 1909 \\
\hline 1702 & & 1807 & 1806 & 1913 \\
\hline 1803 & & 1906 & 1903 & (1914) \\
\hline 1908 & & 1921 & 1907 & (1915) \\
\hline \multirow[t]{28}{*}{ (2006) } & & 2002 & 1910 & 1920 \\
\hline & & 2000 & 1911 & 2001 \\
\hline & & 2017 & 1912 & 2004 \\
\hline & & 2104 & 1916 & 2005 \\
\hline & & 2201 & 1917 & 2012 \\
\hline & & 2301 & 1918 & (2013) \\
\hline & & 2401 & 1919 & 2015 \\
\hline & & 2201 & 2008 & 2016 \\
\hline & & 2301 & 2009 & 2101 \\
\hline & & 2401 & 2010 & $(2102)$ \\
\hline & & 2601 & 2011 & 2103 \\
\hline & & 2701 & 2014 & 2105 \\
\hline & & 2801 & 2111 & 2106 \\
\hline & & & 2501 & 2107 \\
\hline & & & 2901 & $(2108)$ \\
\hline & & & & 2109 \\
\hline & & & & 2110 \\
\hline & & & & 2112 \\
\hline & & & & 2113 \\
\hline & & & & 2114 \\
\hline & & & & 2115 \\
\hline & & & & 2116 \\
\hline & & & & 2117 \\
\hline & & & & 2118 \\
\hline & & & & 3001 \\
\hline & & & & 3101 \\
\hline & & & & 3102 \\
\hline & & & & 3103 \\
\hline
\end{tabular}




\title{
Bijlage 3 Nieuwe technieken
}

\author{
Aanleiding \\ Het goed, betrouwbaar, betaalbaar, nauwkeurig en efficiënt kunnen meten en monitoren van de \\ bodemkoolstofvoorraad en dus ook van vastlegging, is van groot belang. De bodemvoorraad wordt \\ berekend uit het gehalte aan bodemkoolstof en de bulkdichtheid van de bodem. Vanwege de verwachte \\ kleine verandering in bodemkoolstofvoorraad per (paar) jaar, is een hoge nauwkeurigheid in het lab \\ vereist om verschillen betrouwbaar te kunnen waarnemen. Daarnaast zijn effectieve veldmethoden \\ nodig die snel bijsturen en evalueren van maatregelen mogelijk maken. Idealiter zijn deze in het veld \\ op puntniveau en vlakdekkend met voldoende nauwkeurigheid en beperkte kosten te meten voor een \\ snelle aanpassing van de bedrijfsvoering indien nodig. \\ De potentie voor verdere vastlegging wordt bepaald door de huidige concentratie, het landgebruik, de \\ verdere bodemeigenschappen en waterstanden. Daarbij geldt dat een groter bodemvolume meer \\ koolstof zal kunnen vastleggen en dat verdichte lagen het potentiële bodemvolume, waarin koolstof kan \\ worden vastgelegd, verminderen. Daarnaast is bodemverdichting nadelig vanwege verminderde \\ infiltratiecapaciteit bij (piek)buien en minder vocht(na)leverend vermogen bij droogte, afnemende \\ opbrengsten in de landbouw door beperkt wortelvolume, waardoor een grotere gevoeligheid bestaat \\ voor droogte en ziektes.
}

De resultaten van de meetcampagne van 2018 laten zien dat de huidige methoden die worden gebruikt voor het meten van het bodemkoolstofgehalte en de bulkdichtheid nadelen kennen. De huidige meetmethode voor bulkdichtheid, het nemen van steekringen, is arbeidsintensief en daarom duur en langzaam. Wanneer deze methode wordt uitgevoerd door ervaren veldwerkers is deze echter wel nauwkeurig. Het alternatief dat in CC-NL is toegepast, namelijk de methode van afgepaste gutssteken, is weliswaar sneller, maar heeft een grotere onnauwkeurigheid. De metingen voor bodemkoolstofgehalte in het lab zijn nauwkeurig, maar tijdsintensief waardoor lange doorlooptijden zijn geconstateerd en met name de bepaling van C-elementair is duur. Voor beide bepalingen (bodemkoolstofgehalte en bulkdichtheid) zijn nu betere methoden op de markt, die in 2018 zijn aangeschaft.

\section{Bodemkoolstofgehalte meten met infrarode reflectie in het lab en in het veld}

Nabij-infraroodreflectie (NIR) is een techniek om het gehalte aan koolstof in de bodem met redelijke nauwkeurigheid te meten wanneer er een evenwichtige en voldoende grote kalibratie-database voorhanden is voor het doelbereik (Nederlandse bodems) (literatuur en onderzoek door Leandro Barbieri en Stefan de Jong in 2018 onder project 1.4). Eurofins meet op dit moment bijvoorbeeld standaard het gehalte aan organische stof van de bodem met NIR. NIR is toe te passen in het lab en in het veld (bijvoorbeeld Veris scan en AgroCares in Nederland). Uit diverse studies en onderzoek door internationale labs is aangetoond dat metingen van het gehalte aan bodemkoolstof met MIR tot $15 \%$ nauwkeuriger zijn dan met NIR in het lab (zie voor een overzicht Knotters et al., 2017). Voor MIR (mid infrarood) is echter geen betrouwbare veldapparatuur, terwijl deze voor NIR wel beschikbaar is. Voor beide zijn kalibratie-datasets nodig. Voor deze methode worden de lichtreflectie en de absorptie in het nabij- en het mid-infrarode deel van het spectrum per golflengte gemeten. De karakteristiek van het signaal op specifieke golflengtes kan kwantitatief worden toegeschreven aan bodemeigenschappen (organisch en mineraal). Daarbij geldt dat bodemgerelateerde absorptiekarakteristieken vooral voorkomen in het mid-infrarode deel van het spectrum (4000 tot $600 \mathrm{~cm}^{-1}$ ). Overtonen van de verbindingen zorgen voor karakteristieken in het nabij-infrarode deel van het spectrum (700-2500 nm) en dan met name in het short wave infrared (2000-2500 nm). 

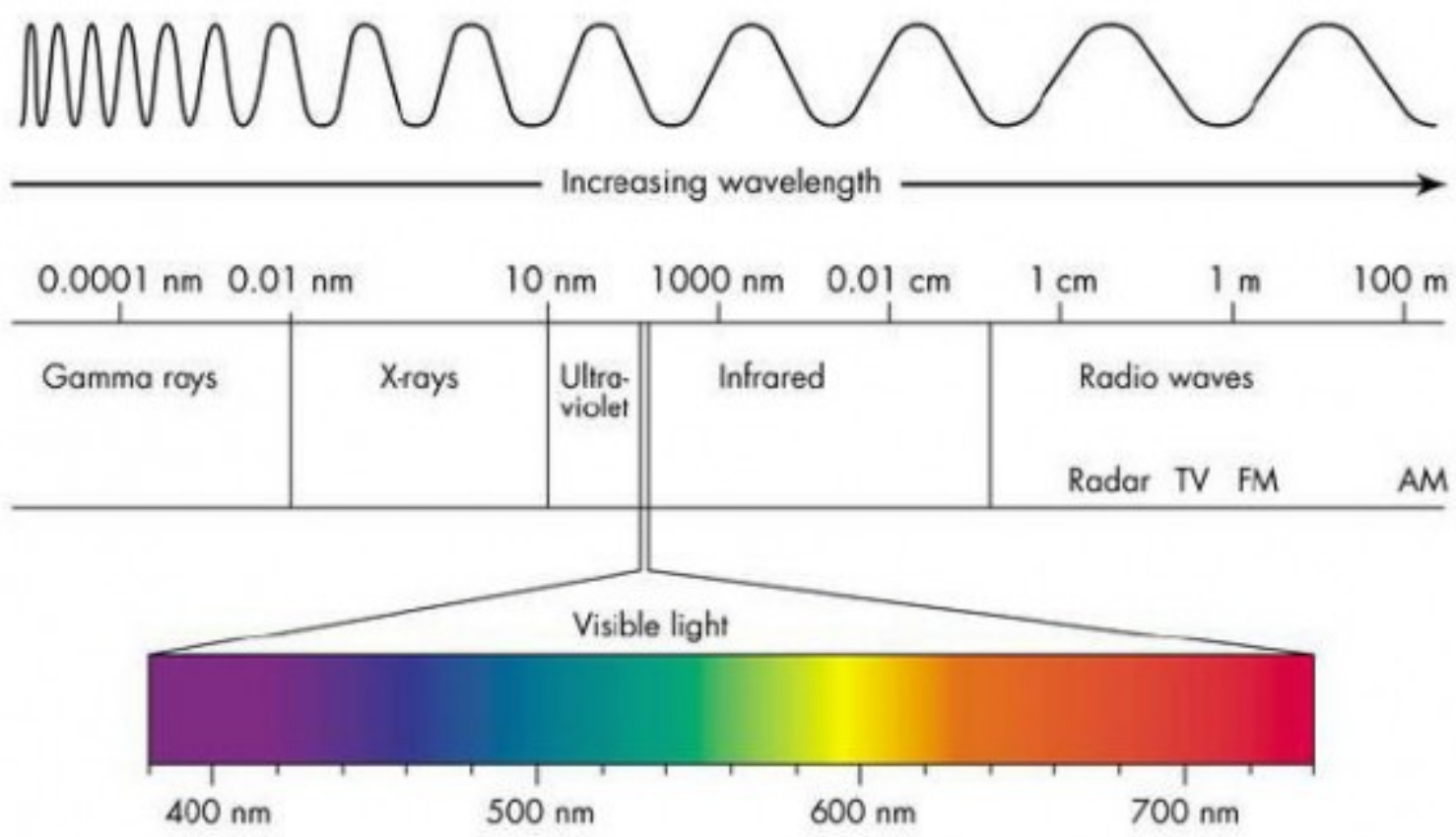

Figuur B3.1 Overzicht elektromagnetisch spectrum.

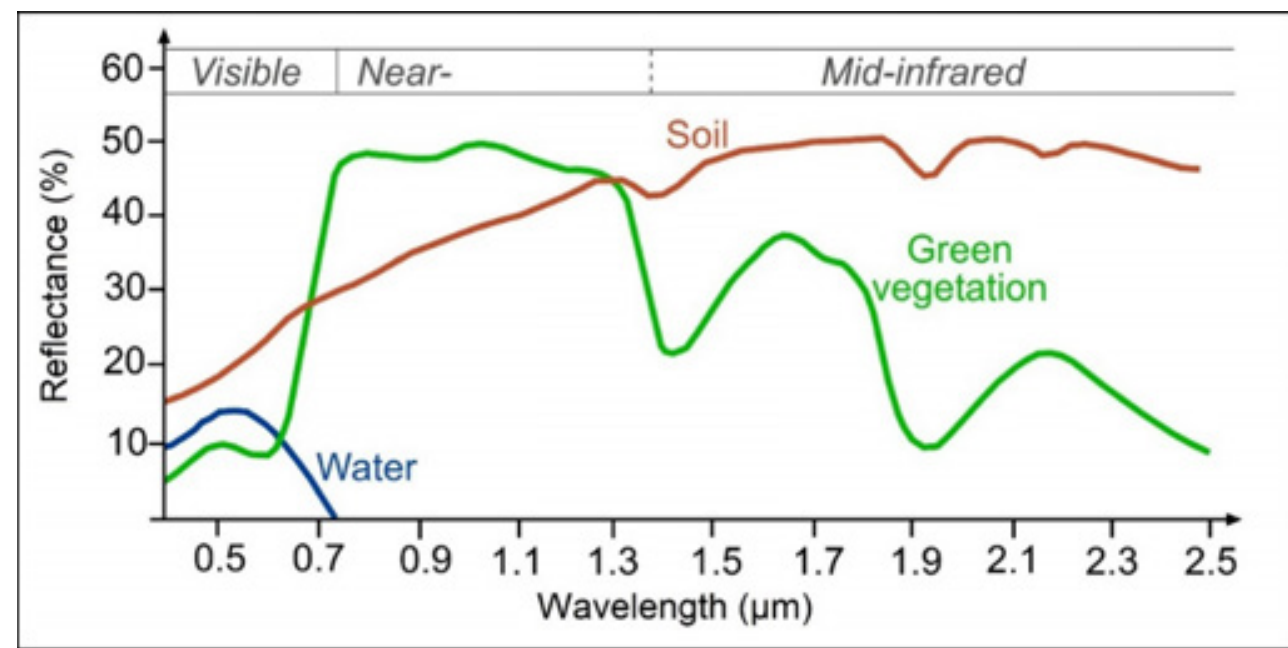

Figuur B3.2 Verschillende materialen hebben elk een eigen karakteristiek spectrum. Dit geldt zowel tussen materiaalgroepen (vegetatie, bodem, water) als binnen materiaalgroepen (veengrond, zandgrond, verschillende gewassen etc.). 


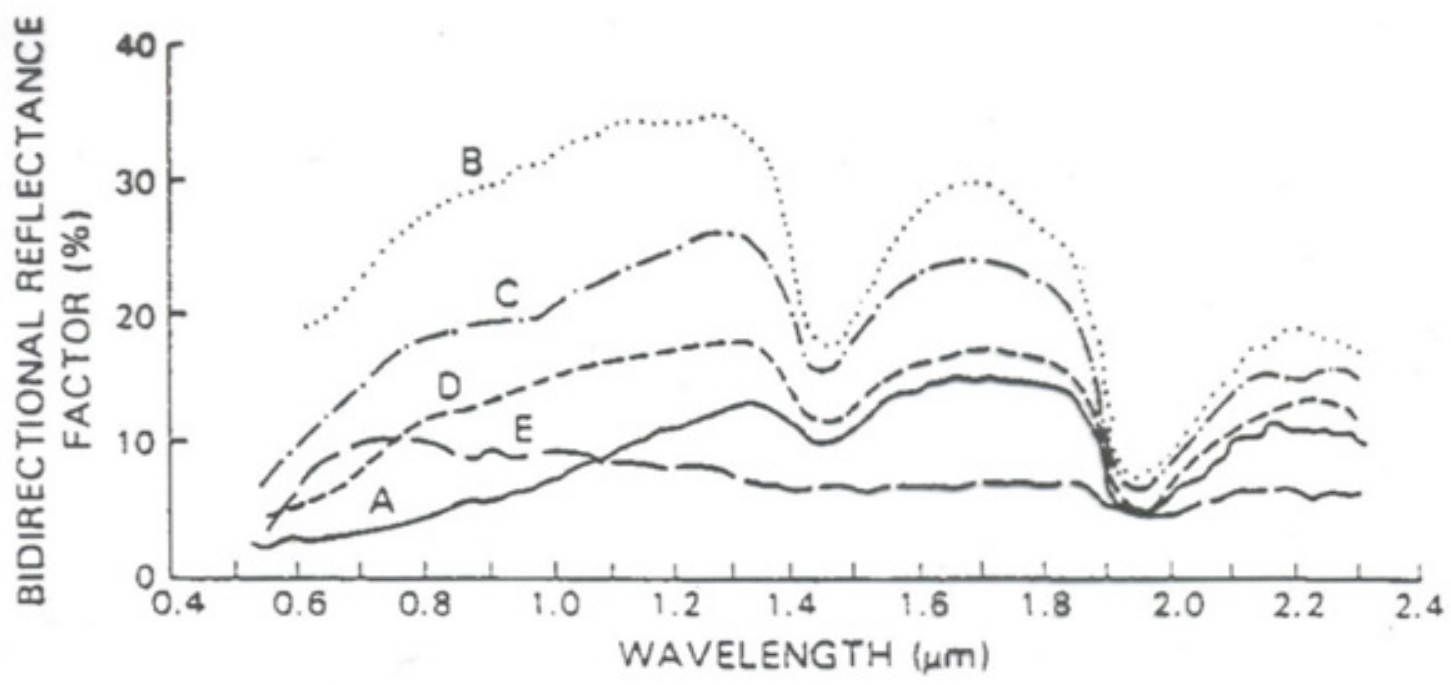

The characteristic soil bidirectional reflectance spectra of Stoner and Baumgardner (1981).

Curve A: soils having high $(>2 \%)$ organic-matter content and fine texture.

Curve B: soils having low $(<2 \%)$ organic-matter content and low $(<1 \%)$ iron-oxide content.

Curve C: soils having low ( $<2 \%$ ) organic-matter content and medium ( 1 to $4 \%$ ) iron-oxide content.

Curve D: soils having high $(>2 \%)$ organic-matter content, low $(<1 \%)$ iron-oxide content, and moderately coarse texture.

Curve E: soils having high $(>4 \%)$ iron-oxide content and fine texture.

(Reproduced from "Characteristic Variations in Reflectance of Surface Soils" by E.R.Stoner and M.F. Baumgardner.

Fig. 1, Soil Science Society of America Journal, Volume 45, No. 6. Pages 1161-1165 by permission of the Soil Science Society of America, Inc.)

Figuur B3.3 verschillende bodems met verschillende bodemeigenschappen hebben specifieke absorptiekarakteristieken (Stoner and Baumgardner, 1981).

Met behulp van een spectral library (set van zowel spectraal als 'traditioneel' gemeten monsters) kunnen nieuwe metingen worden omgerekend naar bodemeigenschappen. De benodigde voorbehandeling van de monsters is minimaal (drogen, malen), waardoor de kans op fouten in het laboratorium wordt verkleind. MIR geeft nauwkeuriger metingen dan NIR. Omdat het signaal gevoelig is voor vocht, bodemstructuur en vegetatie(resten), is de meting betrouwbaarder in het lab. Het voordeel van zowel NIR als MIR is dat de meting snel, effectief, kostenefficiënt, herhaalbaar en non-destructief is. Ook kunnen met deze methode verschillende bodemeigenschappen in een keer worden gemeten, zoals gehalten aan organische stof en bodemkoolstof, kleigehalte en mogelijk andere.

Internationaal worden deze technieken steeds vaker ingezet voor het monitoren van gehalten en voorraden aan bodemkoolstof, organische stof en andere bodemeigenschappen (ICRAF (Afrika), NRCSUSDA (VS), CSIRO (Australië), LUCAS (EU)). De spectral libraries die hiervoor nodig zijn, worden steeds meer opengesteld (NRCS-USDA, global soil spectral library, ICRAF-ISRIC library). In Nederland zijn deze libraries alleen gemaakt door commerciële partijen zoals Eurofins en SoilCares en daarom niet openbaar beschikbaar. Dit betekent een afhankelijkheid in labs, geen inzicht in berekeningsmethoden, representativiteit van de library (nodig voor landsdekkend goede voorspellingen) of nader onderzoek naar de kwaliteit en aanvullende mogelijkheden van de technieken, of keuze in de te gebruiken methoden.

\section{Aangeschafte apparatuur bodemkoolstofmetingen}

Verschillende fabrikanten bieden laboratoriumapparatuur aan voor het meten van mid-infraroodreflectie op bodemmonsters. Daarnaast zijn verschillende goedkope sensoren op de markt voor het meten van de nabij-infraroodreflectie, bijvoorbeeld in het veld. Na zorgvuldige afweging van de mogelijkheden is in 2018 gekozen voor de volgende apparatuur voor laboratorium- respectievelijk veldmetingen:

- Laboratoriummetingen voor nauwkeurig bepalen van bodem-C-concentratie met behulp van midinfrarode reflectie (MIR): Bruker Tensor II FT-IR spectrometer met HTS-XT unit voor midinfraroodmetingen aan bodemmonsters, Retsch MM400 maler met zirconium oxide maalkamers en kogels voor fijnmalen van bodemmonsters voor de Tensor, klein materieel voor gebruik vloeibaar stikstof voor koelen van de Tensor; 
- Veldmetingen voor snel bepalen van gehalten aan bodemkoolstof op basis van nabij-infrarode reflectie (NIR): Scio NIR spectrometer (low end, +/- 300 euro).

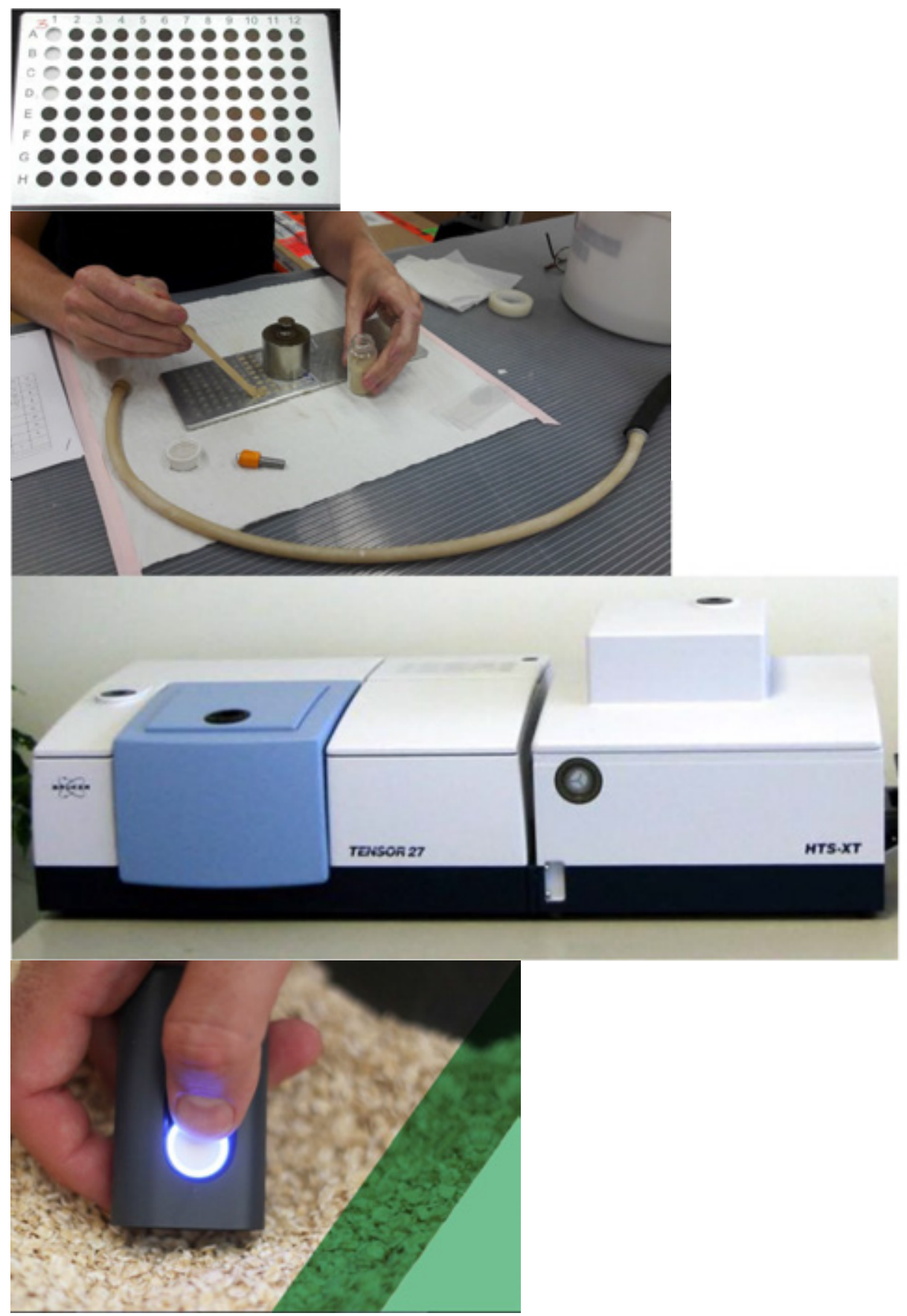

Figuur B3.4 Apparatuur voor metingen van het gehalte aan bodemkoolstof.

Bulkdichtheid meten in het veld met gammastraling

Een methode in opkomst voor het meten van bulkdichtheid is een veldmeting van actieve gammastraling in combinatie met een bodemvochtmeting. We weten dat veldbulkdichtheid kan worden gemeten met een RhoC op basis van afname van gammastraling. Een RhoC met een meetbereik van $1 \mathrm{~m}$ en een diepteresolutie van $5 \mathrm{~cm}$ is aangeschaft voor veldmetingen.

\section{Toepassing van de apparatuur voor onderzoek naar verdichting}

In de Nederlandse landbouw is bodemverdichting een toenemend probleem, al ontbreekt een landsdekkend beeld van de ernst van de verdichting op dit moment. Om vast te stellen of een bodem verdicht is, zijn gegevens nodig van bulkdichtheid, gehalte aan organische stof en kleigehalte, korrelgrootteverdeling en indringingsweerstand of doorlatendheid. Op basis van het gehalte aan 
organische stof, het kleigehalte en de korrelgrootte (zandgronden) kan een grenswaarde voor bulkdichtheid worden bepaald. Uit de bulkdichtheidsmeting kan dan worden afgeleid of de bodem verdicht is of niet. De te meten gegevens zijn bijna dezelfde als voor het bepalen en monitoren van de bodemkoolstofvoorraad. Efficiënt meten van de benodigde parameters met een redelijke nauwkeurigheid, liefst al in het veld, is hiervoor van belang.

Aangeschafte apparatuur bulkdichtheid en vochtgehalte

- Veldmetingen voor snel en nauwkeurig bepalen van droge bulkdichtheid: Medusa MS-Rho veld bulkdichtheidssensor tot $1 \mathrm{~m}$ diepte, Sentek Diviner 2000 bodemvochtsensor tot $1 \mathrm{~m}$ diepte.
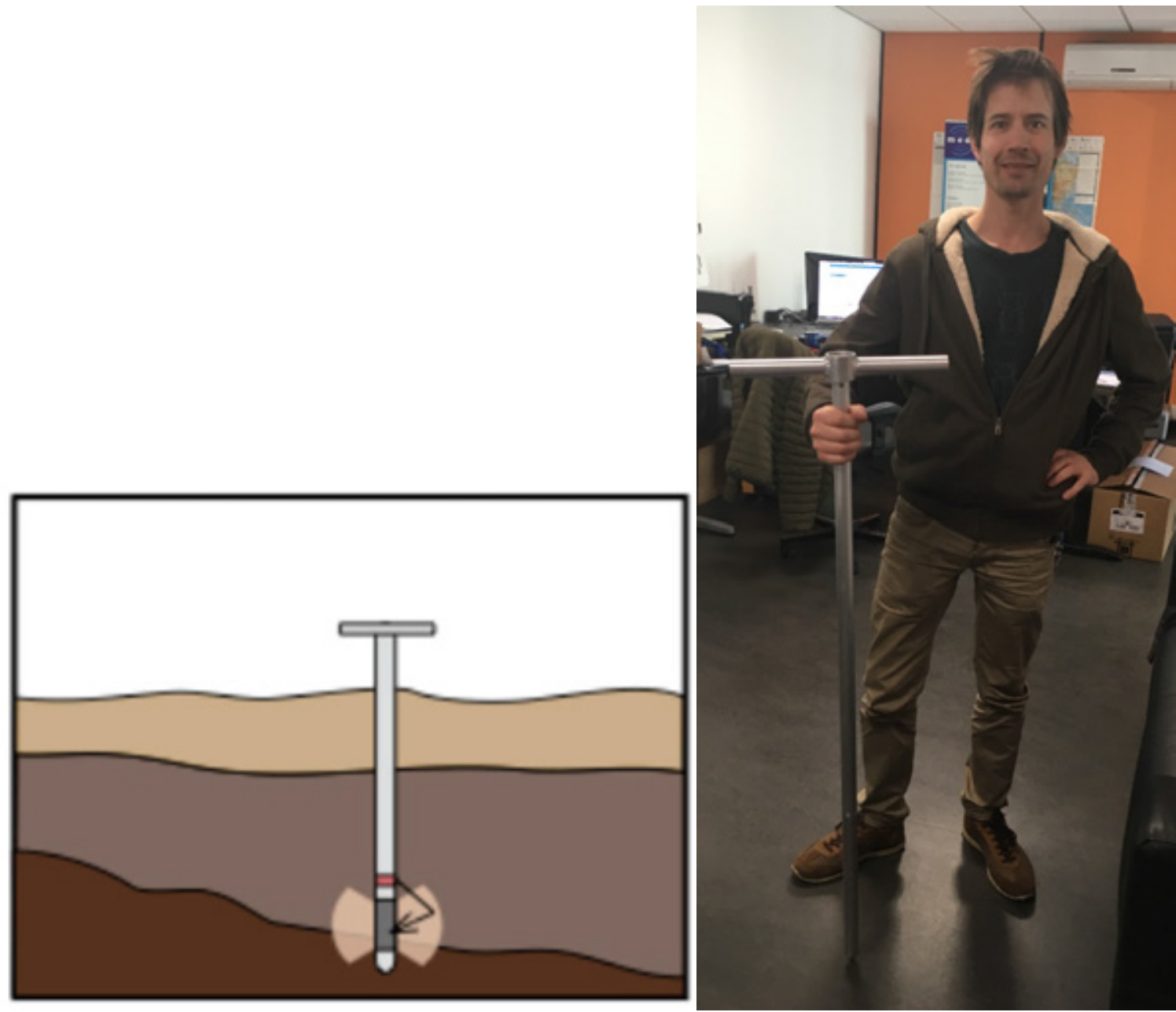

Figuur B3.5 Schematische weergave en foto van MS-Rho: meten van bulkdichtheid tot $1 \mathrm{~m}$ diepte. 


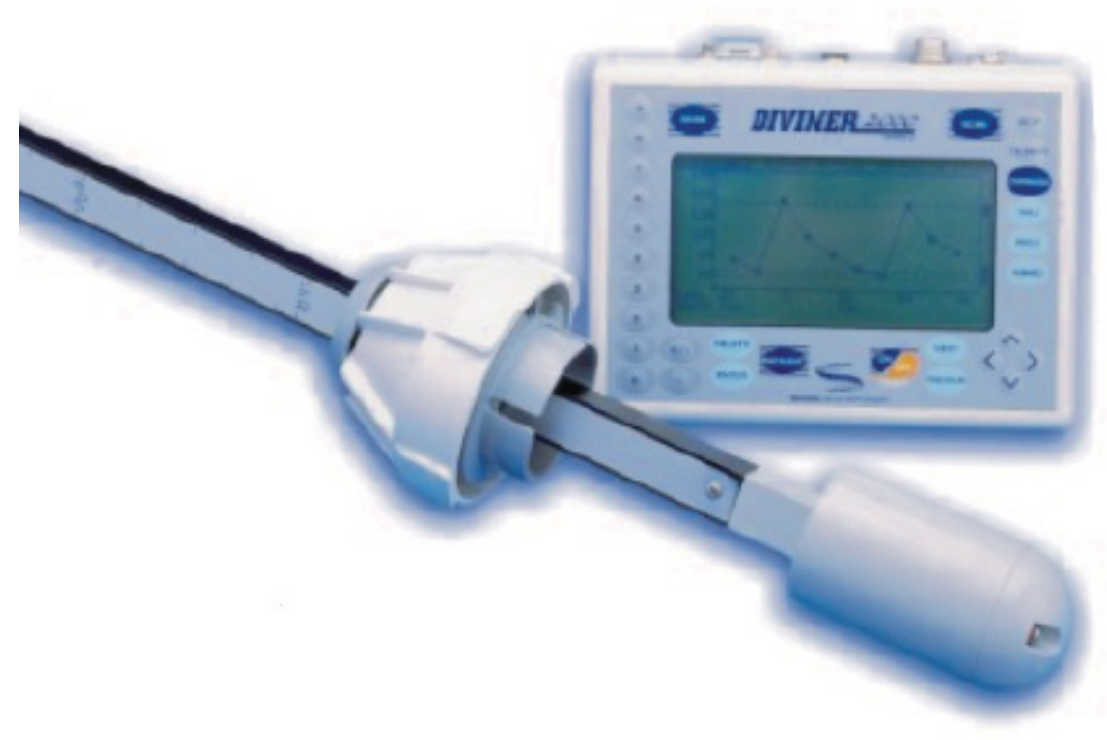

Figuur B3.6 Bodemvocht meten tot $1 \mathrm{~m}$ diepte in 16 stappen met de Sentek Diviner 2000.

Goede afweging tussen meetmethoden mogelijk maken: wat kunnen we ermee en wat kan er bereikt worden?

De aanschaf van deze apparatuur is bedoeld om het bestaande meetinstrumentarium voor het gehalte aan bodemkoolstof en de bulkdichtheid uit te breiden en de technieken die door anderen worden toegepast, te evalueren voor toepassing in monitoring van de bodemkoolstofvoorraad in Nederland op nationaal, regionaal en lokaal niveau.

Het is gewenst om vast te stellen wat de nauwkeurigheid, de herhaalbaarheid, de kosten en de praktische toepasbaarheid van deze methoden is. Dit moet leiden tot een instrumentarium aan inzetbare technieken in het lab en in het veld voor het meten van het gehalte aan bodemkoolstof en de bulkdichtheid om de bodemkoolstofvoorraad vast te kunnen stellen met bekende nauwkeurigheid en kosten, zodat per situatie de juiste keuze kan worden gemaakt.

Een basis hiervoor zijn de monsters en metingen van CC-NL in 2018 en LSK eind jaren negentig. De CC-NL-monsters zijn door Eurofins gemeten met NIR en op de traditionele manier met gloeiverlies. Ook zijn een aantal van de LSK-monsters (voorganger van CC-NL, genomen eind jaren negentig) ingemeten op NIR door WENR. Hiervan zijn metingen beschikbaar van het gehalte aan organische stof met behulp van de gloeiverliesmethode.

Voorgesteld wordt om in samenwerking met Eurofins een representatieve, open spectral library aan te leggen voor NIR en MIR en bodemeigenschappen, zoals gehalte aan organische stof, bodemkoolstof en klei, om voorbereid te zijn op de toekomst en kostenefficiënt en betrouwbaar te kunnen voldoen aan de behoefte aan goede metingen zoals hierboven beschreven.

Deze apparaten en datasets maken het mogelijk een gedegen dataset en testcases op te bouwen waarbij de nauwkeurigheid, betrouwbaarheid, snelheid, praktische uitvoerbaarheid en kosten kunnen worden bepaald van deze meetmethoden.

Dit is te bereiken door:

- met Eurofins de nauwkeurigheid van NIR-metingen in het lab vast te stellen ${ }^{1}$;

- de NIR-dataset te gebruiken om de nauwkeurigheid, toepasbaarheid en kosten van NIR-metingen die in het veld zijn verricht te bepalen, eventueel ook in samenwerking met AgroCares $^{2}$;

- met behulp van de CC-NL- en LSK- data- en monstersets te bepalen wat de nauwkeurigheid is en kosten zijn van de MIR-metingen in het laboratorium;

\footnotetext{
1 Eurofins gebruikt NIR nu meer dan tien jaar standaard voor organische stof metingen en heeft dus een grote dataset.

${ }^{2}$ AgroCares heeft een veld NIR tool (nutrient Scanner), Eurofins heeft dit niet.
} 
- door middel van veldtesten het meten van droge bulkdichtheid en indringingsweerstand in het veld met de MS-Rho, ringen, guts, penetrologger te vergelijken op nauwkeurigheid, toepasbaarheid, snelheid en kosten. Hierbij zal zo veel mogelijk worden aangesloten bij andere projecten in de klimaatenvelop en lopende veldproeven;

- door het analyseren van de toegevoegde waarde van het gebruik van hulpinformatie, zoals landgebruik, bodemkaart, satellietdata en managementinformatie, geïnventariseerd in project 1.7, op het gehalte aan bodemkoolstof, bulkdichtheid en metingen van dichtheid en indringingsweerstand.

Deze testen leiden tot een aanbeveling voor meetmethoden voor bodemkoolstofvoorraad in het laboratorium en in het veld voor komende monitoringscampagnes.

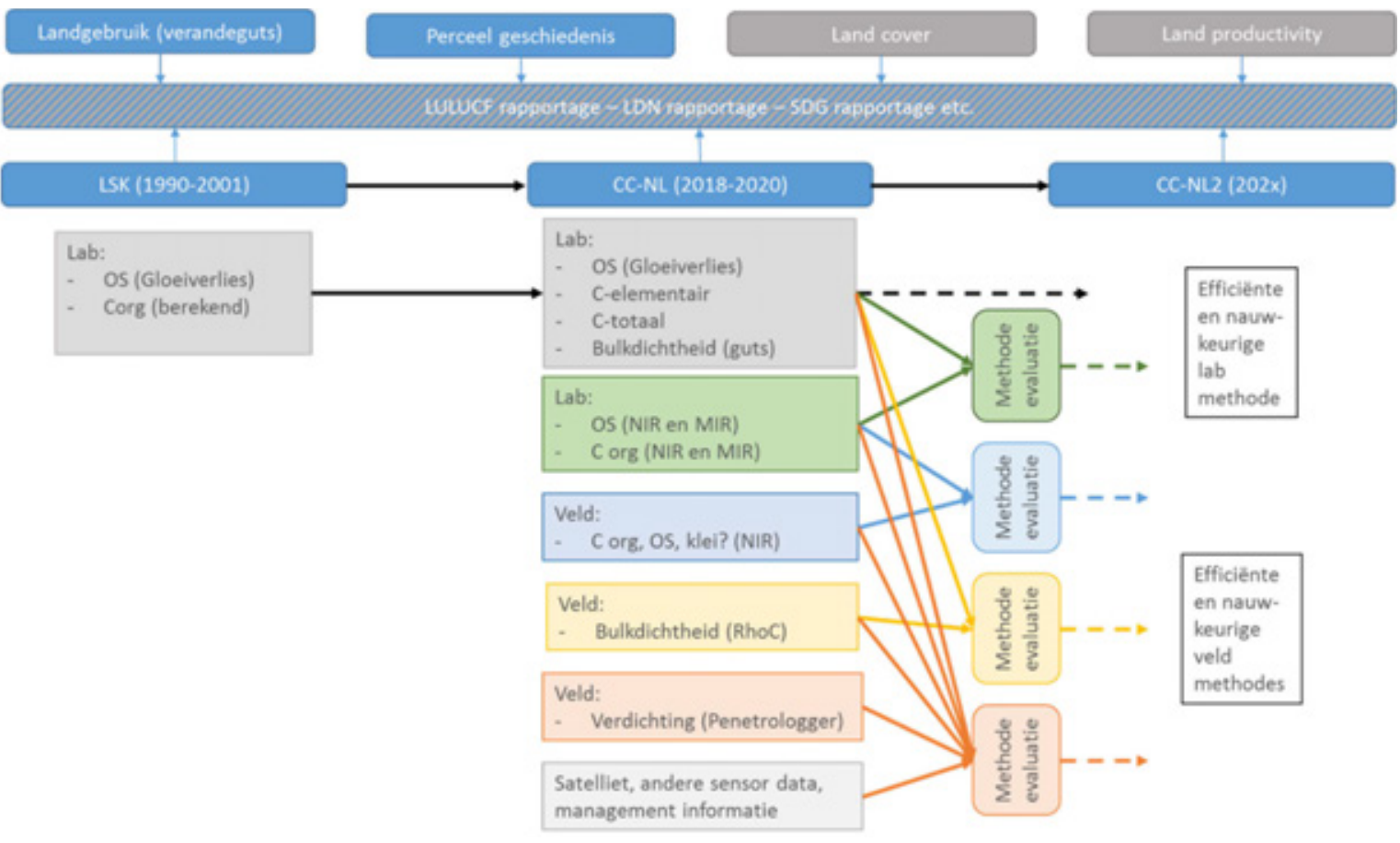

Figuur B3.7 Schematische weergave van het voorgestelde proces. 


\section{Bijlage 4 Analyse-methoden}

De grondmonsters werden gedroogd op $40^{\circ} \mathrm{C}$ en gemalen en gezeefd $(2 \mathrm{~mm})$; dus geen kogelmolen of andere voorbehandelingen waardoor de textuur van de grond wordt aangetast. Het materiaal werd in een glazen potje gedaan (NEN-EN 16179).

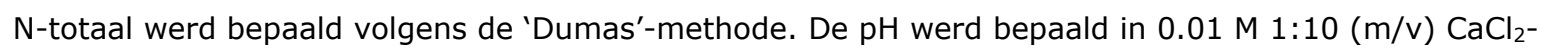
bepaling (eveneens in droge grond) (NEN-ISO 10390). Soil organic matter (SOM), ofwel organische

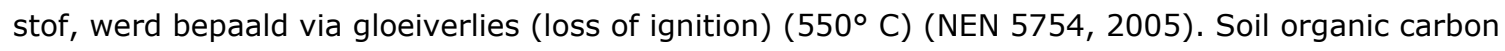
(SOC), ofwel organische koolstof (C), via de C-elementair-methode (C-elemental), verbranding bij $\left(600^{\circ} \mathrm{C}\right.$ ) (ISO 10694). Total Carbon (TOC of TC), ofwel totale koolstof, werd bepaald bij $1150^{\circ} \mathrm{C}$ (NENEN 15936, 2012). TOC is gemeten, maar moet ook te berekenen zijn, omdat TOC = SOC + anorganische koolstof. $\mathrm{C}$-anorganisch en de daarvan afgeleide $\mathrm{CaCO}_{3}$ worden bepaald via Scheibler (NEN-ISO 10693). Kleigehalte via dichtheidsmeting (NEN 5753, 2006).

Naast bovenstaande referentiemethoden werden er ook Near Infra Rood (NIR)-analyses uitgevoerd. NIR is ontwikkeld in de jaren zestig van de vorige eeuw. NIR voor voederwaardeonderzoek is in Nederland sinds 1986 operationeel (en wordt routinematig ingezet). NIR voor grond wordt benut sinds 2004, waarbij kengetallen stapsgewijs zijn geïntroduceerd. Organische stof en organische koolstof en $\mathrm{N}$-totaal worden sinds 2005 routinematig aangeboden, waarbij de klassieke (hierboven vermelde) referentiemethoden wel operationeel blijven (voor onderzoek en validatie) (NEN-EN-ISO 17184, 2014).

Literatuur

www.nen.nl 
Wageningen Environmental Research Postbus 47

6700 AA Wageningen

T 0317480700

www.wur.nl/environmental-research

Wageningen Environmental Research

Rapport 2974

ISSN 1566-7197
De missie van Wageningen University \& Research is 'To explore the potential of nature to improve the quality of life'. Binnen Wageningen University \& Research bundelen Wageningen University en gespecialiseerde onderzoeksinstituten van Stichting Wageningen Research hun krachten om bij te dragen aan de oplossing van belangrijke vragen in het domein van gezonde voeding en leefomgeving. Met ongeveer 30 vestigingen, 5.000 medewerkers en 10.000 studenten behoort Wageningen University \& Research wereldwijd tot de aansprekende kennisinstellingen binnen haar domein. De integrale benadering van de vraagstukken en de samenwerking tussen verschillende disciplines vormen het hart van de unieke Wageningen aanpak. 



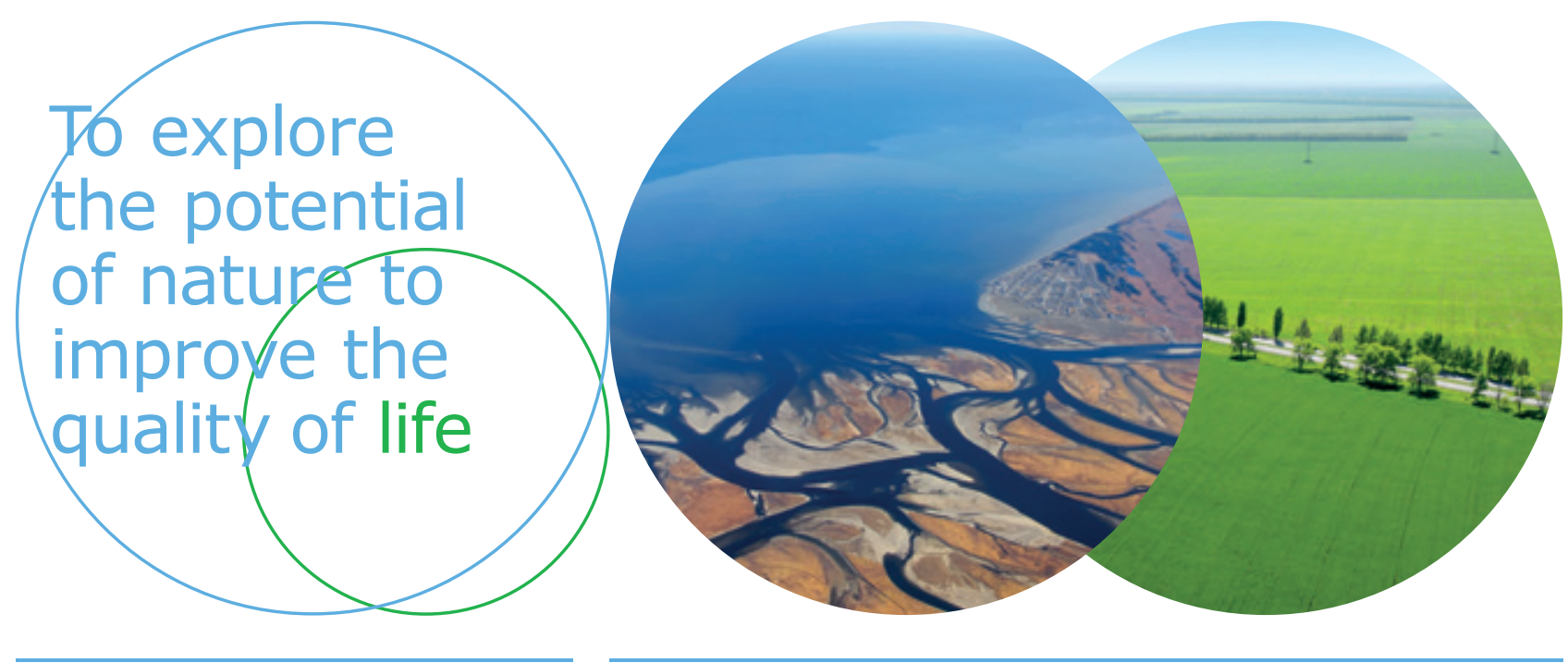

Wageningen Environmental Research Postbus 47

$6700 \mathrm{AB}$ Wageningen

T 317480700

www.wur.nl/environmental-research

Rapport 2974

ISSN 1566-7197
De missie van Wageningen University \& Research is 'To explore the potential of nature to improve the quality of life'. Binnen Wageningen University \& Research bundelen Wageningen University en gespecialiseerde onderzoeksinstituten van Stichting Wageningen Research hun krachten om bij te dragen aan de oplossing van belangrijke vragen in het domein van gezonde voeding en leefomgeving. Met ongeveer 30 vestigingen, 5.000 medewerkers en 10.000 studenten behoort Wageningen University \& Research wereldwijd tot de aansprekende kennisinstellingen binnen haar domein. De integrale benadering van de vraagstukken en de samenwerking tussen verschillende disciplines vormen het hart van de unieke Wageningen aanpak. 